\title{
Metals in Imaging of Alzheimer's Disease
}

\author{
Olga Krasnovskaya ${ }^{1,2, *}$, Daniil Spector ${ }^{1,2, *} \mathbb{1}$, Alexander Zlobin ${ }^{1}$, Kirill Pavlov ${ }^{1}$, \\ Peter Gorelkin ${ }^{1,2}{ }^{-}$, Alexander Erofeev ${ }^{1,2}$, Elena Beloglazkina ${ }^{1}$ and Alexander Majouga ${ }^{1,2,3}$ \\ 1 Chemistry Department, Lomonosov Moscow State University, Leninskie Gory 1,3, 119991 Moscow, Russia; \\ zlobinabchem@gmail.com (A.Z.); kirill.pavlov2011@mail.ru (K.P.); peter.gorelkin@gmail.com (P.G.); \\ Erofeev@polly.phys.msu.ru (A.E.); beloglazki@mail.ru (E.B.); alexander.majouga@gmail.com (A.M.) \\ 2 Department of Materials Science of Semiconductors and Dielectrics, National University of Science and \\ Technology (MISIS), Leninskiy Prospect 4, 101000 Moscow, Russia \\ 3 Mendeleev University of Chemical Technology of Russia, Miusskaya Ploshchad' 9, 125047 Moscow, Russia \\ * Correspondence: krasnovskayao@gmail.com (O.K.); danspector@yandex.ru (D.S.)
}

Received: 10 November 2020; Accepted: 28 November 2020; Published: 2 December 2020

check for updates

\begin{abstract}
One of the hallmarks of Alzheimer's disease (AD) is the deposition of amyloid plaques in the brain parenchyma, which occurs 7-15 years before the onset of cognitive symptoms of the pathology. Timely diagnostics of amyloid formations allows identifying AD at an early stage and initiating inhibitor therapy, delaying the progression of the disease. However, clinically used radiopharmaceuticals based on ${ }^{11} \mathrm{C}$ and ${ }^{18} \mathrm{~F}$ are synchrotron-dependent and short-lived. The design of new metal-containing radiopharmaceuticals for $\mathrm{AD}$ visualization is of interest. The development of coordination compounds capable of effectively crossing the blood-brain barrier (BBB) requires careful selection of a ligand moiety, a metal chelating scaffold, and a metal cation, defining the method of supposed $A \beta$ visualization. In this review, we have summarized metal-containing drugs for positron emission tomography (PET), magnetic resonance imaging (MRI), and single-photon emission computed tomography (SPECT) imaging of Alzheimer's disease. The obtained data allow assessing the structure-ability to cross the BBB ratio.
\end{abstract}

Keywords: Alzheimer disease; amyloid; PET; SPECT; MRI

\section{Introduction}

Alzheimer's disease is the most common form of neurodegenerative disease. This pathology is characterized by the presence of extracellular amyloid plaques and intracellular neurofibrillary tangles (NFTs) in the brain [1]. One of the hallmarks is the extracellular amyloid plaques in aggregated forms of a peptide called amyloid- $\beta(\mathrm{A} \beta)$, appearing years before the onset of symptoms [2-5].

Timely diagnostic imaging plays an important role in managing AD. Several positron emission tomography (PET) imaging agents have been developed that bind to different amyloids, such as 2-(1,1-dicyanopropen-2-yl)-6-(2-[18F]-fluoroethyl)-methylamino-naphthalene [ $\left.{ }^{18} \mathrm{~F}\right] \mathrm{FDDNP}$, $\left[{ }^{11} \mathrm{C}\right]$ Pittsburgh Compound-B (PiB), $\left[{ }^{18} \mathrm{~F}\right]$ Florbetapir, $\left[{ }^{18} \mathrm{~F}\right]$ Florbetaben, and $\left[{ }^{18} \mathrm{~F}\right]$ Flutemetamol, allow obtaining semiquantitative information about amyloid deposition in patients, which allows presaging the development of clinical symptoms of AD 7-15 years before their occurrence [6-10] (Figure 1). But using these drugs requires an expensive laborious synthesis with confirmation of radio purity at each stage. The short half-lives of the currently used radionuclides ${ }^{11} \mathrm{C}(20.4 \mathrm{~min})$ and ${ }^{18} \mathrm{~F}$ (109.8 min) may also limit the widespread use of these imaging agents [11,12].

Although metal cations such as $\mathrm{Cu}(\mathrm{II}), \mathrm{Zn}(\mathrm{II})$, and $\mathrm{Fe}(\mathrm{III})$ proved to coordinate undesirably with histidine residues at the $N$-terminus of $A \beta$, promoting $A \beta$ aggregation and stabilization of $A \beta$ oligomers [13], an increased accumulation of these metals in $A \beta$-amyloids raises the possibility of 
designing $\mathrm{Cu}(\mathrm{II})_{-}, \mathrm{Zn}(\mathrm{II})-$, and $\mathrm{Fe}(\mathrm{III})$-based metal complexes for the diagnosis and theranostics of $\mathrm{AD}$. AD diagnostic agents radiolabeled with ${ }^{64} \mathrm{Cu}$ are attractive not only due to the simple and fast introduction of radionuclide at the last stage of non-radioactive synthesis, but also due to the $12.7 \mathrm{~h}$ half-life of ${ }^{64} \mathrm{Cu}$ radionuclide, ideal for PET imaging [14].
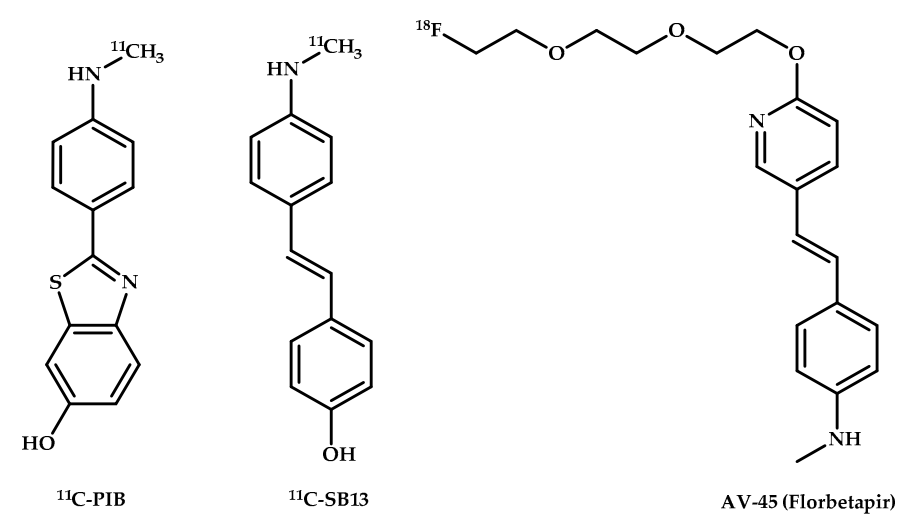

Figure 1. Pittsburgh compound B (PiB), [11C]4-N-Methylamino-4'-hydroxystilbene (SB-13), and Florbetair (AV-45), AD PET imaging agents.

Another promising PET radionuclide is ${ }^{68} \mathrm{Ga}$. Positron-emitting ${ }^{68} \mathrm{Ga}$ can be obtained from a ${ }^{68} \mathrm{Ge} /{ }^{68} \mathrm{Ga}$ generator, which would allow a cyclotron-independent distribution of PET. The parent nuclide, ${ }^{68} \mathrm{Ge}$, has a half-life of 271 days, and the generators can provide sufficient quantities of ${ }^{68} \mathrm{Ga}$ for up to one year, resulting in a relatively inexpensive and reliable source of a positron-emitting radionuclide $[15,16]$.

In addition to PET imaging of amyloids, single-photon emission computed tomography (SPECT) and magnetic resonance imaging (MRI) are alternative diagnostic tools for AD visualization, able to overcome the limitations of PET imaging in terms of cost and broad accessibility [17]. The technetium-99 $\mathrm{m}\left({ }^{99 \mathrm{~m}} \mathrm{Tc}\right)$ radioisotope for SPECT imaging can be cyclotron-independently prepared by a ${ }^{99} \mathrm{Mo} /{ }^{99 \mathrm{~m}} \mathrm{Tc}$ generator [18]. The MRI imaging allows nonradioactive diagnostics and is also cheaper and faster than PET imaging. The $\mathrm{Gd}^{3+}$ PET imaging agents for $\mathrm{A} \beta$ visualization are also of interest [19].

The development of effective diagnostic and therapeutic agents targeting amyloid is not a trivial task. The blood-brain barrier (BBB) is a highly selective, semipermeable barrier, consistent of cerebrovascular endothelial cells, surrounded by extracellular matrix, astrocytes, and pericytes [20], which prevents potential therapeutics from reaching the cerebral target, thus limiting their efficacy [21]. Various approaches to effective brain delivery are developed, such as chemical drug delivery systems [22], e.g., a drug conjugation with dihydropyridine, mannitol, or aromatic substances [23], physical methods, such as focused ultrasound [24] or sonophoresis [25], and biological methods, e.g., drug conjugation with polycationic proteins or amino acids [26].

The complexity of the architecture of the blood-brain barrier, as well as the significant difficulties accompanying the development of drugs capable of overcoming it, prompts the creation of in vitro models of the BBB, such as microfluidic models [27], brain organoids [28], and microvascular systems [29].

The BBB permeability of a compound is related to its lipophilicity, expressed by the water/octanol partition coefficient, $\log \mathrm{P}_{\text {oct/water, }}$ molecular weight $(\mathrm{MW})$, and plasma pharmacokinetics [30]. Low-MW amphiphilic molecules with $\log \mathrm{P}_{\text {oct/water }} \approx 2$ have optimal BBB penetration [31]. Conjugating an $A \beta$-affinity moiety, a metal-chelating moiety, and a metal cation in one scaffold is often difficult, and the resulting drugs are often unable to cross the BBB.

Sedgwick et al. summarized metal-based imaging agents for neurodegenerative disease diagnostics [32]. Gomes et al. also summarized an interaction of metal complexes with the A $\beta$ peptide [33]. Liu et al. reported potential applications of metal-based agents in therapy, diagnosis, and theranosis of $\mathrm{AD}[34]$. 
In this review, we summarize various solutions in the design of amyloid-affinity drugs capable of effectively crossing the $\mathrm{BBB}$, and different approaches for designing $\mathrm{A} \beta$-affinity drugs for diagnosing AD. Three summary tables can be conveniently used to evaluate the structure of the ligand and the result of brain penetration by the coordination compound based on it, noting the successful and unsuccessful attempts to create drugs for diagnosing AD. This review will be useful to researchers for developing approaches for designing $\mathrm{A} \beta$-affinity drugs for both the therapy and diagnostics of AD.

\section{Copper Coordination Compounds for PET Imaging of Alzheimer Disease}

PET diagnostics is based on registering a pair of gamma quanta resulting from the annihilation of electrons and positrons that arise during the positron-beta decay of a radionuclide. Annihilation of the positron, which remained in the tissue, with one of the electrons of the medium, generates two gamma quanta with the same energy, scattering in opposite directions along one straight line. A set of detectors makes it possible to obtain a three-dimensional reconstruction of the distribution of the radionuclide in the body tissue [35].

The radionuclide ${ }^{64} \mathrm{Cu}$ has a long half-life $\left(\mathrm{t}_{1 / 2}=12.7 \mathrm{~h}, \beta^{+}=17 \%, \beta^{-}=39 \%\right.$, e-capture decay $\mathrm{EC}=43 \%, \mathrm{E}_{\max }=0.656 \mathrm{MeV}$ ) and can be considered an ideal PET tracer [36]. Copper-coordination compounds are promising for PET diagnostics of AD because of not only the emission properties but also the increased affinity of amyloids for copper cations, which would further increase the accumulation of copper-containing drugs in the therapeutic target [37].

A standard approach in developing A $\beta$ PET imaging drugs is a conjugation of an A $\beta$-binding benzothiazole, benzofuran, or stilbene scaffold, with a metal-chelating moiety. Thiosemicarbazone derivatives are often used as a metal-chelating agent, based on the diacetylbis( $\mathrm{N}(4)$ methylthiosemicarbazonato Cu-ATSM drug [38].

Lim et al. [39] developed a bis(thiosemicarbazonato)copper(II) complex 1 (all numbers of coordination compounds are bold through all the manuscript) conjugated with a stilbene functional group (Figure 2). A fluorescent assay with thioflavin-T (Th-T) showed a drop in the fluorescence $(485 \mathrm{~nm})$ after an addition of coordination compound 1, meaning a displacement of thioflavin. Also, examination by transmission electron microscopy (TEM) of the structural morphology of the A $\beta$ fibrils pre-treated with coordination compound $\mathbf{1}$ showed significant changes in morphology. Epi-fluorescence microscopy of AD human brain sections with E18 antibody revealed a co-localization of the immunostained and epi-fluorescent images. Biodistribution of radiolabeled ${ }^{64} \mathrm{Cu}-\mathbf{1}$ in wild-type mice and APP/PS1 transgenic mice (Tg-mice) after intravenous tail vein injection ( $85 \mathrm{MBq}$ ) showed a significantly higher brain uptake in APP/PS1 Tg-mice compared with their wild type (Table 1).

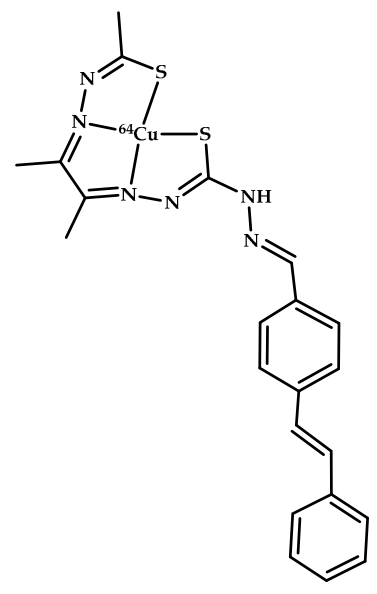

1

Figure $2 .{ }^{64} \mathrm{Cu}(\mathrm{II})$-ATSM derivative $\mathbf{1}$ conjugated with stilbene functional group, designed for $\mathrm{A} \beta$ fibrils visualization. 
Table 1. $\mathrm{Cu}(\mathrm{II})$-based coordination compounds for positron emission tomography (PET) imagining of Alzheimer disease.

\begin{tabular}{|c|c|c|c|c|c|}
\hline $\begin{array}{c}\text { Coordination } \\
\text { Compound Number }\end{array}$ & $\begin{array}{l}\text { Brain Uptake, ID/g, } 2 \text { min } \\
\text { Post-Injection, } \%\end{array}$ & $\begin{array}{c}\text { Brain }_{2 \min } / 60 \min \\
\left({ }^{*} \text { Brain }_{2 \min } / 30 \min \right) \text { Ratio }\end{array}$ & Brain Tissue Experiments & A $\beta$ Binding Moiety & Reference \\
\hline & & \multicolumn{4}{|c|}{$\mathrm{Cu}(\mathrm{ATSM})$-based coordination compounds } \\
\hline 1 & $\begin{array}{c}2.5 \pm 0.6(\text { APP/PS1 } \\
\text { transgenic mice) } \\
1.7 \pm 0.6 \text { (Wild-type mice) } \\
7 \text { min after injection }\end{array}$ & - & $\begin{array}{l}\text { Epi-fluorescence microscopy of } \\
\text { AD human brain sections }\end{array}$ & Stilbene & [39] \\
\hline $2-4$ & $1.11 \pm 0.20$ & $2.92 *$ & $\begin{array}{l}\text { Epi-fluorescence microscopy of } \\
\text { AD human brain sections }\end{array}$ & 2-benzothiazole,3,4-styrylpyridine & [40] \\
\hline $5-8$ & $\begin{array}{l}1.39 \pm 0.06 \\
1.06 \pm 0.43 \\
0.77 \pm 0.19 \\
1.54 \pm 0.60\end{array}$ & $\begin{array}{l}1.31^{*} \\
2.16^{*} \\
1.05^{*}\end{array}$ & $\begin{array}{c}\text { Elemental composition of AD } \\
\text { human brain tissue using } \\
\text { LA-ICP-MS }\end{array}$ & Benzofuran & [41] \\
\hline 9 & - & - & $\begin{array}{l}\text { Epi-fluorescence microscopy of } \\
\text { AD human brain tissue (ligand) }\end{array}$ & Stilbene & [42] \\
\hline $10-15$ & $\begin{array}{l}2.2 \pm 0.6 \\
1.1 \pm 0.2\end{array}$ & $\begin{array}{c}6.47 \\
5\end{array}$ & $\begin{array}{l}\text { Epi-fluorescence microscopy of } \\
\text { AD human brain sections }\end{array}$ & Styrylpyridine & [43] \\
\hline $16-25$ & $\begin{array}{c}4.41 \pm 0.23 \\
(23 \text { h Post-injection similar) }\end{array}$ & - & PET imagine of BALB/c mice & - & [44] \\
\hline \multicolumn{6}{|c|}{ Other metal-chelating moieties } \\
\hline 26,27 & $\begin{array}{l}0.33 \pm 0.12 \\
0.36 \pm 0.10\end{array}$ & $\begin{array}{l}1.83 \\
2.11\end{array}$ & $\begin{array}{l}\text { Fluorescent staining using brain } \\
\text { sections from a Tg2576 mice }\end{array}$ & Benzofuran & [45] \\
\hline 29-33 & $\begin{array}{l}0.37 \pm 0.06 \\
0.17 \pm 0.02 \\
1.33 \pm 0.27 \\
0.49 \pm 0.01 \\
0.61 \pm 0.14 \\
0.75 \pm 0.16\end{array}$ & $\begin{array}{l}2.64 \\
1.30 \\
4.92 \\
2.22 \\
4.69 \\
2.88\end{array}$ & $\begin{array}{l}\text { Fluorescent imaging of amyloid } \\
\text { plaques in Tg2576 AD mice } \\
\text { brain sections }\end{array}$ & Benzothiazole & {$[46,47]$} \\
\hline $34-39$ & $\begin{array}{l}0.16 \pm 0.02 \\
0.99 \pm 0.04\end{array}$ & $\begin{array}{l}1.59 \\
4.95\end{array}$ & $\begin{array}{l}\text { Fluorescence imaging of } \\
\text { amyloid plaques in 5xFAD mice } \\
\text { brain sections }\end{array}$ & Benzothiazole & [48] \\
\hline
\end{tabular}

${ }^{*}$ Brain $_{2 \min } / 30 \mathrm{~min}$ ratio is indicated instead of $\mathrm{Brain}_{2 \mathrm{~min}} / 60 \mathrm{~min}$ ratio. 
The same Donnelly group reported a copper radiopharmaceutical $\mathrm{Cu}(\mathrm{II})$-ATSM with an appended styrylpyridine functional group for $A \beta$ plaque imaging [40] (Figure 3). Binding of 3 and 4 (coordination compound 2 was quite insoluble) to $A \beta$ plaques was clearly evident, as demonstrated by epi-fluorescence microscopy. The A $\beta$-specific $1 \mathrm{E} 8$ antibody was used as a control. The biodistribution of coordination compounds 3 and 4 radiolabeled with ${ }^{64} \mathbf{C u}$ in wild-type mice after intravenous tail injection ( 13 MBq) displayed good brain uptake of coordination compound 4 in $1.1 \%$.

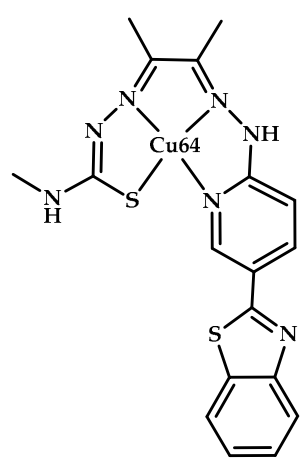

2

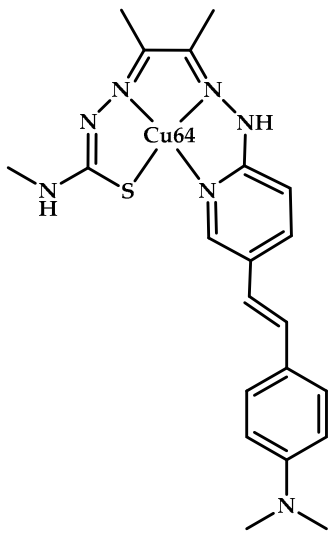

3

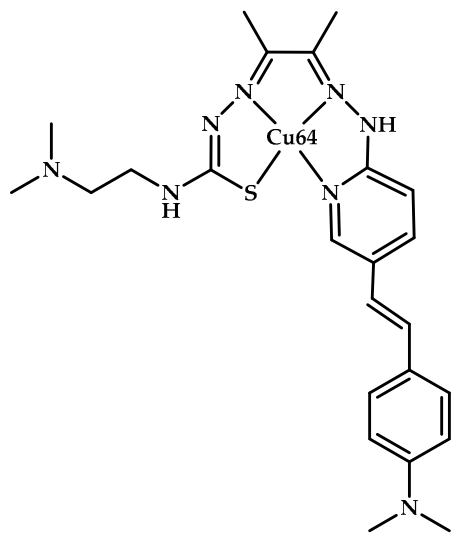

4

Figure 3. ${ }^{64} \mathrm{Cu}(\mathrm{II})$-ATSM derivatives conjugated $2-4$ with benzothiazole/styrylpyrydine functional group, designed for $A \beta$ fibrils visualization.

In 2019 [41], the Donnely group reported a synthesis of four hybrid thiosemicarbazonatobenzofuran ligands and their copper complexes (Figure 4). Addition of either 6 or 8 to $A \beta_{1-42}$ results in dramatic changes in the structural morphology, as identified by the TEM images. The AD human brain tissue samples treated with 8 were analyzed for elemental composition using the laser ablation inductively coupled plasma mass spectrometry (LA-ICP-MS) assay by tracking the change in the ratio ${ }^{65} \mathrm{Cu} /{ }^{63} \mathrm{Cu}$. A sample of nonradioactive isotopically enriched ${ }^{65} \mathrm{Cu}-8$ was used to distinguish biologically present copper from the complex. Coordination compound 3 was used as a control. The benzofuran-containing complex ${ }^{65} \mathrm{Cu}-8$ appears to bind with improved differentiation compared with the styryl-pyridine-containing complex ${ }^{65} \mathrm{Cu}-3$ and potentially offers better sensitivity for amyloid. The complex preferentially binds to areas of the brain enriched with $\mathrm{A} \beta$ plaques, which was confirmed by immunohistochemistry with an aged-match control. The biodistribution of coordination compounds 5-8 radiolabeled with ${ }^{64} \mathrm{Cu}$ in wild-type mice showed the best brain uptake results for coordination compound 8 (1.54\% of injected dose (ID)/g at $2 \mathrm{~min}$ after injection, dropping to $0.77 \% \mathrm{ID} / \mathrm{g}$ at $30 \mathrm{~min})$.

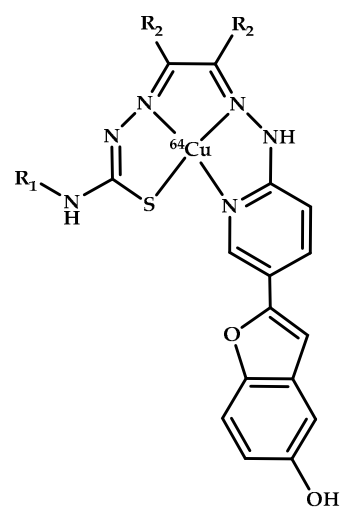

5. $\mathrm{R}_{1}=\mathrm{R}_{2}=\mathrm{CH}_{3}$ 6. $\mathrm{R}_{1}=\mathrm{CH}_{2} \mathrm{CH}_{3}, \mathrm{R}_{2}=\mathrm{CH}_{3}$ 7. $\mathrm{R}_{1}=\mathrm{CH}_{3}, \mathrm{R}_{2}=\mathrm{CH}_{2} \mathrm{CH}_{3}$ 8. $\mathrm{R}_{1}=\mathrm{R}_{2}=\mathrm{CH}_{2} \mathrm{CH}_{3}$

Figure 4. ${ }^{64} \mathrm{Cu}(\mathrm{II})-\mathrm{ATSM}$ derivatives 5-8 conjugated with benzofuran functional group, designed for $\mathrm{A} \beta$ fibrils visualization. 
McInne [42] incorporated a 4-vinylpyridine functional group to investigate whether the complex 9 binds to $A \beta$ plaques with an additional pyridyl hydrogen bond acceptor at the expense of the electron-donating dimethlylamino and hydroxy groups (Figure 5). Comparing the fluorescence from the 9-treated AD human brain tissue with (1E8)-treated brain tissue revealed good co-localization.
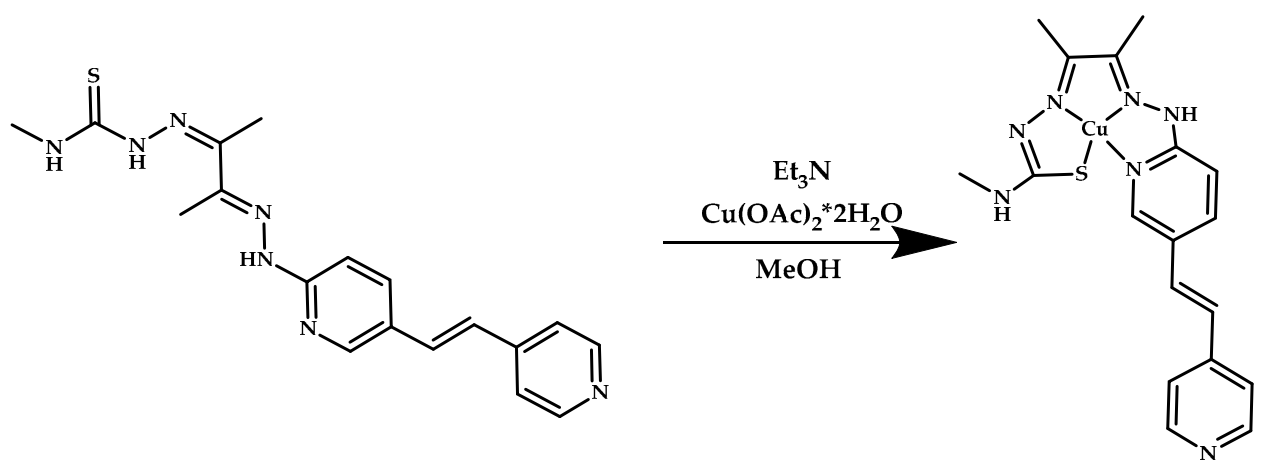

Figure 5. $\mathrm{Cu}(\mathrm{II})-\mathrm{ATSM}$ derivative conjugated with piridylstilbene functional group 9, designed for $\mathrm{A} \beta$ fibrils visualization.

This research group recently presented several structural analogues (10-15) of coordination compound 3, where the bis-(thiosemicarbazone) moiety is conjugated to stilbene functional groups [44] (Figure 6). All coordination compounds significantly alter the emission intensity of the ThT/A $\beta$ conjugate. Compounds $\mathbf{1 1}$ and $\mathbf{1 5}$ were selected as lead compounds because of the ease of synthesis. The TEM of $A \beta_{1-40}$ fibrils preincubated with $\mathbf{1 1}$ and $\mathbf{1 5}$ reveal a dramatic change in fibril morphology. Epi-fluorescence microscopy on human AD brain tissue proved an ability of $\mathbf{1 1}$ and $\mathbf{1 5}$ to bind amyloid- $\beta$ plaques, which was also confirmed by A $\beta$-specific antibody (1E8) staining. Experiments with wild-type mice showed high brain uptake for both $\mathbf{1 1}$ and $\mathbf{1 5}$ at $2 \mathrm{~min}$ after the injection $(2.2 \%$ and $1.1 \%$, respectively), followed by rapid removal after $1 \mathrm{~h}$.

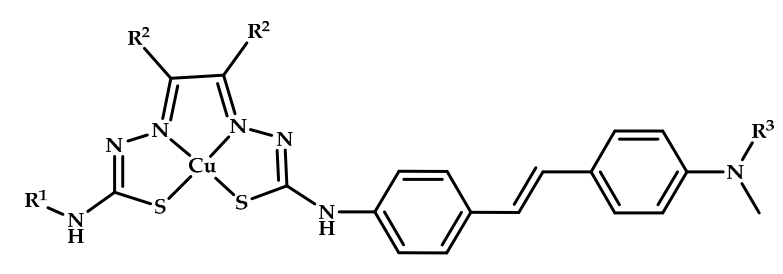

$$
\begin{aligned}
& \text { 10: } R^{1}=R^{2}=\mathrm{CH}_{3} ; R^{3}=\mathrm{H} \\
& \text { 11: } R^{1}=R^{2}=\mathrm{CH}_{3} ; R^{3}=\mathrm{CH}_{3} \\
& \text { 12: } R^{1}=\mathrm{CH}_{3} ; R^{2}=\mathrm{CH}_{2} \mathrm{CH}_{3} ; R^{3}=\mathrm{H} \\
& \text { 13: } R^{1}=\mathrm{CH}_{3} ; R^{2}=\mathrm{CH}_{2} \mathrm{CH}_{3} ; R^{3}=\mathrm{CH}_{3} \\
& \text { 14: } R^{1=}=R^{2}=\mathrm{CH}_{2} \mathrm{CH}_{3} ; R^{3}=\mathrm{H} \\
& \text { 15: } R^{1}=R^{2}=\mathrm{C}_{2} \mathrm{H}_{5} ; R^{3}=\mathrm{CH}_{3}
\end{aligned}
$$

Figure 6. $\mathrm{Cu}(\mathrm{II})-\mathrm{ATSM}$ derivatives conjugated with stilbene functional groups 10-15, designed for A $\beta$ fibrils visualization.

Observing the various design steps of the PET binding agents developed under Donnelly's leadership, we note that they achieved significant improvements in brain uptake (Table 1, lines 3-7).

Paterson et al. [44] developed a series bis(thiosemicarbazones) 16-25 with amine and polyamine functional groups in order to increase the BBB permeability of the complexes (Figure 7). Intracellular uptake of the complexes was measured by inductively coupled plasma mass spectrometry (ICP-MS). Intracellular accumulation decreased in the order $17>[19+2 \mathrm{H}]^{2+}>[21+\mathrm{H}]^{+}>[23+\mathrm{H}]^{+}$ $>[25+3 \mathrm{H}]^{3+}$. Biodistribution studies were performed using small-animal micro-PET imaging. The complexes with a secondary amine, $\mathbf{2 1}$, and a primary amine functional group, 23 , showed little to no radioactivity in the brain. The complex with a pendent secondary amine, $\mathbf{1 7}$, had a relatively high level of brain uptake. 


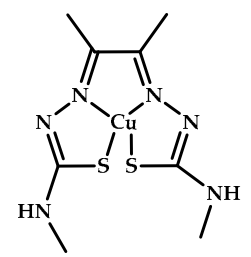

16<smiles>CNC1=NN2C(C)=C(C)N3N=C(NCCN)SC23S1</smiles>

19

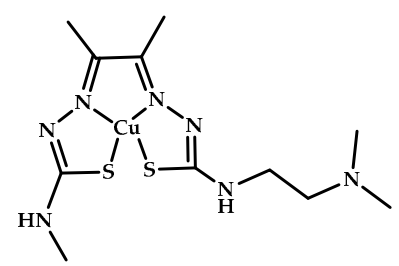

17

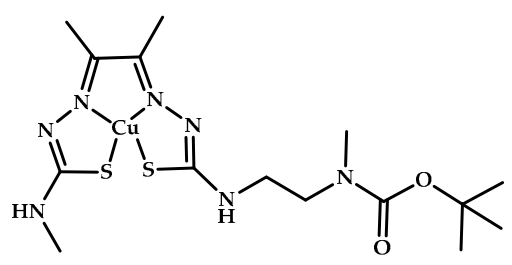

20<smiles>CNC1=NN2C(C)=C(C)N3N=C(NCCNC(=O)OC(C)(C)C)SC23S1</smiles>

18<smiles>CNC1=NN2C(C)=C(C)N3N=C(NCCCCN)S[C@@]23N=C(NC)S1</smiles>

22

23<smiles>[Z19]C1=C(C)N2N=C(NCCCNCCCCNCCCN)S[C@]23SC(NC)=NN3C(C)=N1</smiles>

Figure 7. $\mathrm{Cu}(\mathrm{II})$-ATSM derivatives conjugated with polyamines $\mathbf{1 6}-\mathbf{2 5}$, designed for $\mathrm{A} \beta$ fibrils visualization.

The authors designed these complexes not as PET imaging agents for amyloids, but as hypoxia-sensitive agents capable of accumulating in malignant tumors. But the impressive results of brain penetration shown by complex 17 (injected activity/per gramm IA/g at $23 \mathrm{~h}$ after injection was $2.43 \%$ ) again convince us of the promising potential of copper-containing preparations as diagnostic agents for imaging brain pathologies. Ex vivo biodistribution analysis of 17-preinjected BALB/C mice bearing EMT6 tumors showed a $4.17 \% \pm 1.03 \%$ injected activity per gram of tissue at $40 \mathrm{~min}$ post-injection, and $4.41 \% \pm 0.23 \%$ injected activity per gram of tissue in the brain.

Therefore, Cu-ATSM-based agents are interesting both as redox-active agents sensitive to hypoxia, capable of accumulation in solid tumors, and as highly penetrating agents for therapy and diagnostics of brain pathologies.

Conjugates containing $\mathrm{A} \beta$-binding and metal-chelating moieties were found to modulate the aggregation of $\mathrm{A} \beta_{42}$ species $[49,50]$. Therefore, ${ }^{64} \mathrm{Cu}$ coordination compounds based on them are expected to bind $A \beta$ effectively. 
Watanabe et al. designed and synthesized two novel ${ }^{64} \mathrm{Cu}$-labeled benzofuran derivatives 26 and 27 with cyclen (1,4,7,10-tetraazacyclododecane) or DOTA $(1,4,7,10$ - tetraazacyclododecane1,4,7,10-tetraacetic acid) as chelators [45] (Figure 8).

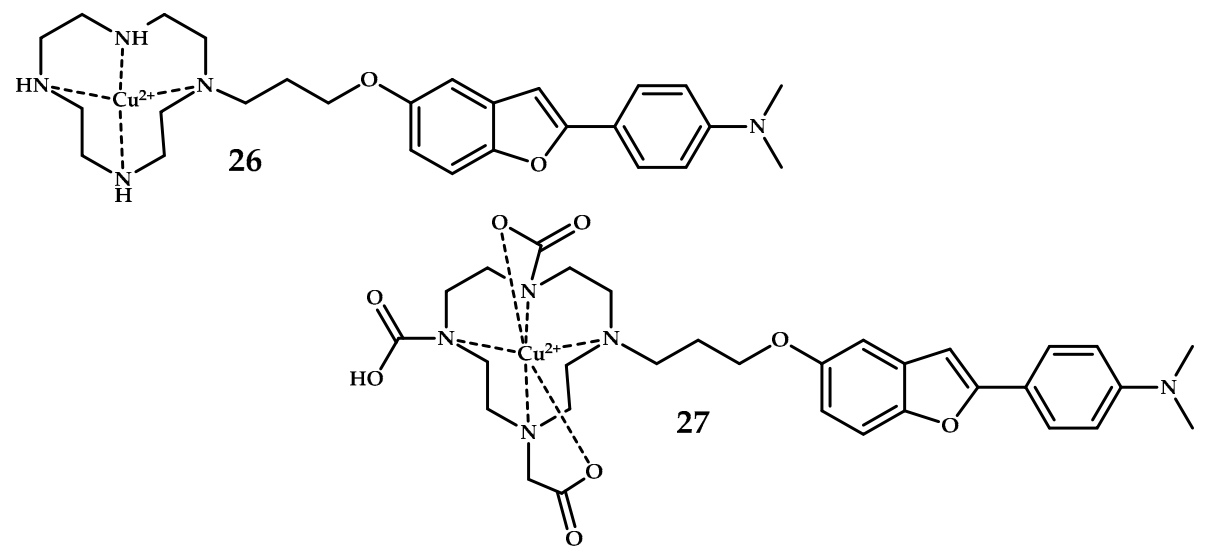

Figure 8. Benzofuran moiety, conjugated with metal-chelating cyclen 26 or 1,4,7,10tetraazacyclododecane-1,4,7,10-tetraacetic acid (DOTA) 27, designed for A $\beta$ fibrils visualization.

An in vitro binding assay with ([125I]6-iodo-2-(40-dimethylamino)-phenyl-imidazo [1,2-a] pyridine) $\left[{ }^{125} \mathrm{I}\right] \mathrm{IMPY}$ as the competitive ligand showed dose-dependent inhibition with $\mathrm{K}_{\mathrm{i}} 33.7 \pm 14.6$, $243.5 \pm 88$.2. Fluorescent staining using Tg2576 mice brain sections proved the amyloid-binding ability of 26 to a greater extent than 27. Unfortunately, biodistribution studies revealed quite low brain uptake equal to $0.33 \%$ and $0.36 \%$, respectively.

Sharma et al. designed a series of copper-coordination compounds based on an A $\beta$-binding 2-phenylbenzothiazole moiety, conjugated with metal-chelating macrocyclic 1,4,7-triazacyclononane (tacn) and 2,11-diaza [3.3]-(2,6)pyridinophane $\left(\mathrm{N}_{4} \mathrm{H}_{2}\right)$ 29-33 [46,47] (Figure 9). The ThT fluorescence competition assay suggests a good affinity L29-L33 for A $\beta_{40}$ fibrils. Fluorescence microscopy studies on Tg2576 APP Tg-mice brain sections, with amyloid-binding Congo Red as a control, showed a specific binding for organic ligands L29-L33. The ThT competition assays with copper complexes 29-33 also revealed a strong A $\beta$ binding affinity for 32. A specific binding of the ${ }^{64} \mathrm{Cu}-$ labeled L29-L33 to $\mathrm{A} \beta$ plagues was proven using ex vivo autoradiography studies on brain sections of $\mathrm{Tg} 2576$ mice and wild-type mice as a control in the absence and presence of a known A $\beta$-specific blocking agent (B1). Coordination compounds 29-33 showed a significant $A \beta$ binding: the autoradiography intensity markedly decreased in the presence of B1 blocking agent. Biodistribution studies in normal CD-1 mice showed the highest brain uptake of $1.33 \% \pm 0.27 \% \mathrm{ID} / \mathrm{g}$ at $2 \mathrm{~min}$ post-injection for 29 . The PET/CT imaging of the $\operatorname{Tg} 2576$ mice showed a radiotracer accumulation in the head and neck area for 29, 31, and 32. Coordination compound 29 shows the highest brain uptake of $0.57 \% \pm 0.05 \% \mathrm{ID} / \mathrm{g}$ in post-PET biodistribution analysis.

Huang et al. developed a series of compounds based on classical amyloid-binding moiety Pittsburg compound B and used fragments 1,4-dimethyl-1,4,7-triazacyclononane (tacn) as the metal-chelating group [48] (Figure 10). The ThT fluorescence competition assays showed nanomolar affinities for the $A \beta_{1-40}$ for organic ligands L34 and L35. Staining with 5xFAD mice brain sections showed significant A $\beta$-binding affinity of the organic ligands L34-36 and L39. The $\mathrm{Cu}^{2+}$ complexes 35, 36, and 39 also showed significant A $\beta$ binding. The MTT (3-(4,5-dimethylthiazol-2-yl)-2,5-diphenyl-2H-tetrazolium bromide) cell viability assays on mice neuroblastoma ( $22 a)$ cells showed that coordination compounds 35, 37, and 38 exhibit no appreciable cell toxicity. Unfortunately, determination of the octanol/phosphate-buffered saline (PBS) partition coefficient values revealed that ${ }^{64} \mathrm{Cu}-\mathrm{labeled}$ complexes 37 and 38 exhibit $\log \mathrm{D}_{\text {oct }}$ values of 0.6 , suggesting that 2-pyridyl-benzothiazole derivatives may be too hydrophilic to cross the BBB. 
<smiles>O=C(O)CN(CC(=O)O)Cc1cccc(CN(CC(=O)O)Cc2ccccc2)n1</smiles>

L28<smiles>CCN(C)CCN(C)CCN(CCN(C)C)Cc1cc(-c2nc3ccccc3s2)cc(OC)c1O</smiles>

L29<smiles>COc1cc(-c2nc3ccccc3s2)cc(CN(Cc2cccc(-c3nc4ccccc4s3)c2)Cc2cccc(CN(Cc3cc(OC)c(O)c(OC)c3)Cc3cccc(-c4nc5ccccc5s4)n3)n2)c1O</smiles>

L33

$\mathrm{L} 31: \mathrm{R}=\mathrm{Me}$

L32: $\mathrm{R}=\mathrm{CH}_{2} \mathrm{CO}_{2} \mathrm{H}$

Figure 9. Benzothiazole moieties, conjugated with metal-chelating 1,4,7-triazacyclononane and 2,11-diaza[3.3]-(2,6)pyridinophane L29-L33, designed for A $\beta$ fibrils binding, and model ligand L28 without benzotiazole moiety.<smiles>CN1CCN(C)CCN(Cc2c(O)ccc3nc(-c4ccc(N(C)C)cc4)sc23)CC1</smiles>

L34<smiles>CNc1ccc(-c2nc3ccc(O)c(CN4CCN(C)CCN(C)CC4)c3s2)cc1</smiles>

L35<smiles>CNc1ccc(-c2nc3ccc(O)c(CCCN(CCCC(C)C)Cc4c(O)ccc5nc(-c6ccc(NC)cc6)sc45)c3s2)cc1</smiles>

L36<smiles>CN1CCN(C)CCN(Cc2c(O)ccc3nc(-c4ccc(N(C)C)nc4)sc23)CC1</smiles>

L37<smiles>CNc1ccc(-c2nc3ccc(O)c(CN4CCN(C)CCN(C)CC4)c3s2)cn1</smiles>

L38

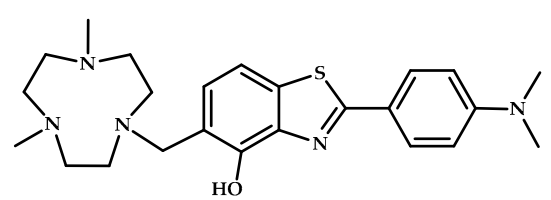

L39

Figure 10. Pittsburg compound B derivatives, conjugated with metal-chelating 1,4-dimethyl-1,4,7triazacyclononane L34-L39, designed for A $\beta$ fibrils binding. 
Ex vivo autoradiography studies using brain sections of 5xFAD Tg-mice confirmed an amyloid-binding specificity of radiolabeled coordination compounds 35,36 , and 39 , but ${ }^{64} \mathrm{Cu}$-labeled 34 also exhibits nonspecific binding. The MW of 36 was found to be too large for efficient brain uptake. Biodistribution studies in normal CD-1 mice proved 39 to cross the BBB, while 35 showed low brain uptake.

\section{3. $\mathrm{Gd}^{3+}$ and $\mathrm{Ga}^{3+}$ Coordination Compounds for $\mathrm{A} \beta$ Visualization}

Another promising emerging radionuclide for PET is ${ }^{68} \mathrm{Ga}$. Positron-emitting ${ }^{68} \mathrm{Ga}$ can be obtained from a ${ }^{68} \mathrm{Ge} /{ }^{68} \mathrm{Ga}$ generator, which would facilitate cyclotron-independent distribution of PET. The parent nuclide ${ }^{68} \mathrm{Ge}$ has a half-life of 271 days, and the generators can provide sufficient quantities of ${ }^{68} \mathrm{Ga}$ for up to one year, resulting in a relatively inexpensive and reliable source of a positron-emitting radionuclide [51]. $\mathrm{Ga}^{3+}$ is a hard acid metal that can make strong bonds with hard base ligands such as carboxylic acids, amino nitrogen hydroxamates, and phenolates [52], which leads to the tendency to use rigid oxygen-containing chelating structures in ${ }^{68} \mathrm{Ga}$-based drug candidates, such as 1,4,7,10-tetraazacyclododecane-1,4,7,10-tetraacetic acid DOTA.

MRI is an imaging technique based on the physical phenomenon of nuclear magnetic resonance. Various structural and functional changes including atrophy, vascular dysfunction, or changes in the volume of the hippocampus can be quantified using anatomical MRI [53]. Gadolinium(III) is the constituent of most MRI contrast agents due to a large magnetic moment (spin only effective magnetic moment $\mu_{\text {eff }} \frac{1}{4} 7.94 \mathrm{BM}$, from seven half-filled f-orbitals) and a long electron-spin relaxation time (108 to $109 \mathrm{~s}$, from the symmetric $S$ electronic state) [54]. Table 2 summarizes the coordination compounds for magnetic resonance imaging (MRI) and single-photon emission computed tomography (SPECT) diagnostics of Alzheimer's disease, based on amyloid-affinity ligands conjugated with various metal chelating moieties:

Table 2. $\mathrm{Gd}^{3+}, \mathrm{Ga}^{3+}$ coordination compounds for magnetic resonance imaging (MRI) and single-photon emission computed tomography (SPECT) imaging of AD.

\begin{tabular}{|c|c|c|c|c|c|c|}
\hline № & Brain Uptake, \% & $\begin{array}{l}\text { Diagnostic } \\
\text { Method }\end{array}$ & Metal & $\begin{array}{l}\text { Metal- Chelating } \\
\text { Moiety }\end{array}$ & $\begin{array}{l}\text { A } \beta \text {-binding } \\
\text { Moiety }\end{array}$ & Reference \\
\hline $40-42$ & $\begin{array}{c}\text { Cellebrium } \\
0.50 \pm 0.07 \\
\text { Cortex } \\
0.36 \pm 0.03\end{array}$ & $\begin{array}{l}\text { MRI } \\
\text { SPECT }\end{array}$ & $\mathrm{Gd}^{3+},{ }^{111} \mathrm{In}^{3+}$ & DO3A & $\mathrm{PiB}$ & [55] \\
\hline 43,44 & $\begin{array}{l}- \\
-\end{array}$ & MRI & $\mathrm{Gd}^{3+}$ & DO3A & $\mathrm{PiB}$ & [56] \\
\hline $45-60$ & & MRI & $\mathrm{Gd}^{3+}$ & $\begin{array}{l}\text { DOTA } \\
\text { PCTA }\end{array}$ & $\begin{array}{l}\text { Benzothiazole } \\
\text { Benzoxazole } \\
\text { Stilbene }\end{array}$ & [57] \\
\hline $\begin{array}{c}61 \\
62-64\end{array}$ & - & $\begin{array}{l}\text { PET } \\
\text { PET }\end{array}$ & $\begin{array}{l}\mathrm{Ga}^{3+} \\
\mathrm{Ga}^{3+}\end{array}$ & $\begin{array}{l}\text { DOTA } \\
\text { DOTA }\end{array}$ & $\begin{array}{l}\text { Benzofuran } \\
\text { PiB }\end{array}$ & $\begin{array}{l}{[58]} \\
{[59]}\end{array}$ \\
\hline 65-70 & $\begin{array}{l}0.12 \pm 0.05 \\
0.17 \pm 0.05 \\
0.31 \pm 0.09 \\
0.21 \pm 0.05 \\
0.22 \pm 0.03 \\
0.11 \pm 0.01\end{array}$ & PET & $\mathrm{Ga}^{3+}$ & HBED-CC & Styrylpyridine & [60] \\
\hline 71 & $1.24 \pm 0.31$ & PET & $\mathrm{Ga}^{3+}$ & \multicolumn{2}{|c|}{ Chalkone } & [61] \\
\hline $\begin{array}{l}72 \\
74\end{array}$ & No brain uptake & - & $\mathrm{Ga}^{3+}$ & \multicolumn{2}{|c|}{ Curcumin } & {$[62,63]$} \\
\hline 75 & $\begin{array}{c}\text { No biodistribution } \\
\text { experiment }\end{array}$ & - & $\mathrm{Ga}_{3+}$ & $\begin{array}{c}\mathrm{N}_{2} \mathrm{O}_{2} \text { Schiff- base } \\
\text { ligand }\end{array}$ & Curcumin & [64] \\
\hline 76,77 & & - & $\mathrm{Ga}^{3+}$ & $\begin{array}{l}\text { NODAGA } \\
\text { AAZTA }\end{array}$ & Curcumin & [65] \\
\hline $78-88$ & $\begin{array}{c}0.21 \pm 0.07(5 \mathrm{~min} \\
\text { p.i. })\end{array}$ & $\begin{array}{c}\text { PET } \\
\text { SPECT }\end{array}$ & $\begin{array}{c}\mathrm{Ga}^{3+} \\
{ }_{99} \mathrm{Tc}^{3+}\end{array}$ & DOTA & Tacrine & [66] \\
\hline
\end{tabular}


Martins et al. have designed an amyloid-targeted ligand that can efficiently complex different metal ions for various imaging modalities, including $\mathrm{Gd}^{3+}$ for MRI and ${ }^{111} \mathrm{In}^{3+}$ for SPECT imaging by a conjugation of a cyclen-based macrocycle DO3A (1,4,7,10-tetraazacyclododecane-1,4,7-triacetic acid) with a benzothiazole moiety [55]. Ligand L40-based complexes of $\mathrm{Gd}^{3+}, \mathrm{Eu}^{3+}$, and ${ }^{111} \mathrm{In}^{3+}$ were obtained (Figure 11).
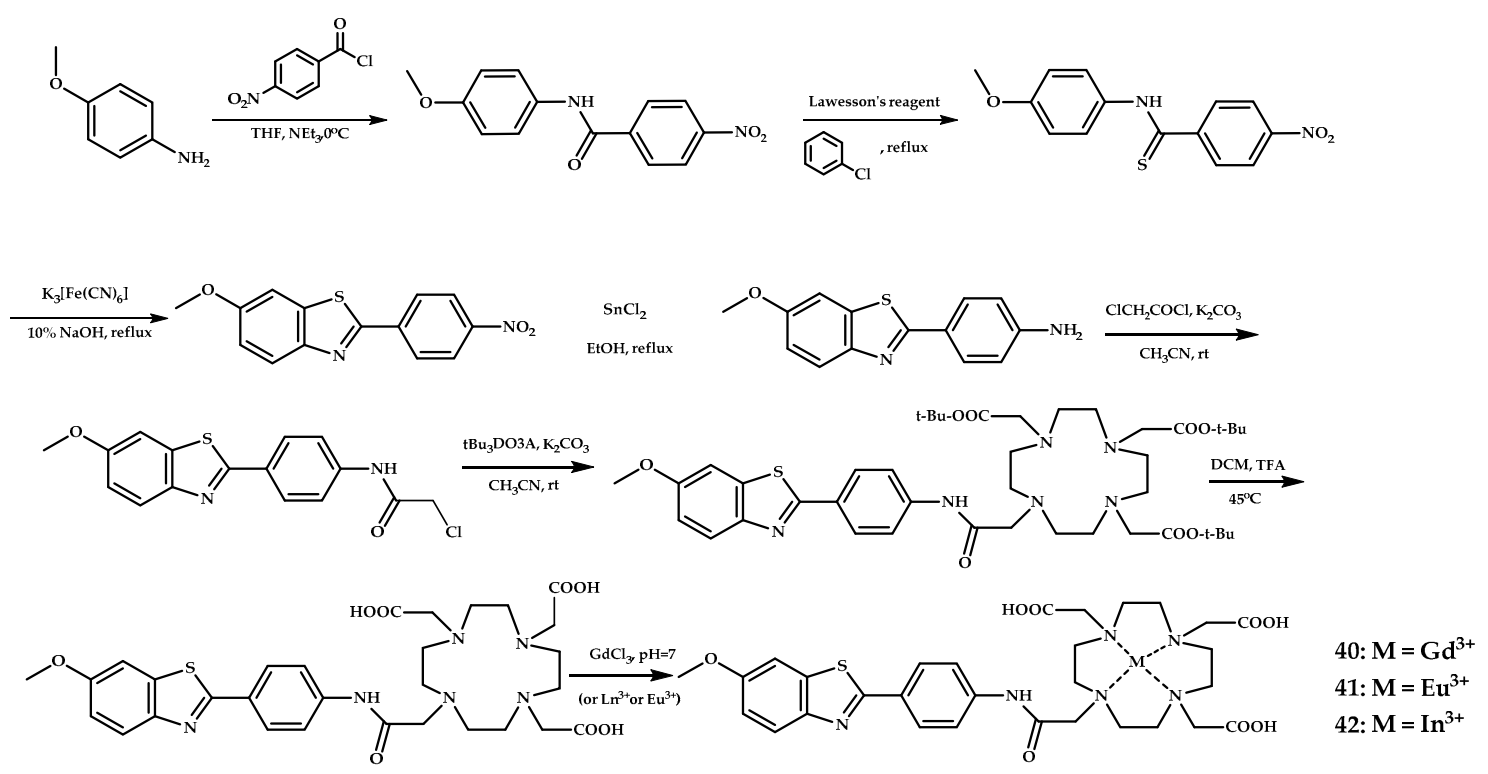

Figure 11. Synthesis of $A \beta$-specific DO3A-benzothiazole ligand $\mathbf{L} 40$ and coordination compounds 40 $\left(\mathrm{Gd}^{3+}\right), 41\left(\mathrm{Eu}^{3+}\right)$, and $42\left(\mathrm{In}^{3+}\right)$ based on it, designed for MRI and SPECT A $\beta$ fibrils visualization.

Upon binding of 40 to $A \beta$ plaques, higher relaxivity in nuclear magnetic relaxation dispersion (NMRD) profiles was observed due to the complex becoming immobilized during plaque binding. A binding affinity of 40 to $A \beta_{1-40}$ was evaluated by surface plasmon resonance measurements and yielded $K_{d}=(180 \pm 10) \mu \mathrm{M}$, and similar $K_{d}$ values were also expected for the $\mathrm{Eu}^{3+}$ and $\mathrm{In}^{3+}$ analogues $\mathbf{4 1}$ and $\mathbf{4 2}$. The binding affinity of $\mathbf{4 0}$ to HSA was assessed by proton relaxation enhancement measurements and yielded $K_{d}=110 \pm 20 \mu \mathrm{M}$. A specific binding of 41 to $A \beta$ deposits was proved on postmortem human brain tissue of $\mathrm{AD}$ patients using fluorescence staining with $\mathrm{PiB}$ and thioflavin-S as controls. Unfortunately, the $\log \mathrm{P}$ oct/water -0.15 value for $\mathbf{4 0}$ and also the high $\mathrm{MW}=842$ shows that the complex is not optimized to cross the BBB. In vivo biodistribution experiments with the radiolabeled ${ }^{111} \mathrm{In}$-analogue $\mathbf{4 2}$ in adult male Swiss mice showed that cortex and cerebellum penetration $\mathrm{ID} / \mathrm{g}$ at $2 \mathrm{~min}$ was $0.36 \%$ and $0.5 \%$, respectively.

Martins et al. subsequently presented two novel DO3A monoamide derivative ligands conjugated to the PiB moiety, $\mathbf{4 3}$ and $\mathbf{4 4}$, via linkers differing in length and chemical structure to improve the log P-value and to enhance BBB penetration of the complexes [56] (Figure 12).

The amphiphilic compounds $\mathbf{4 3}$ and $\mathbf{4 4}$ were found to form micelles in solution. Analysis of the rotational dynamics for micelles formed using the Lipari-Szabo approach indicated highly flexible large aggregates. The coordination compounds $\mathbf{4 3}$ and $\mathbf{4 4}$ were unable to cross the BBB, and the amount detected was found to be insufficient for MRI detection.

Bort et al. reported amyloid-targeted hydroxybenzothiazole, hydroxybenzoxazole, and hydroxytrans-stilbene moieties conjugated via neutral and positive-charged linkers with PCTA (3,6,9,15-tetraaza bicyclo[9.3.1]-pentadeca1(15),11,13-triene-3,6,9-triacetic acid) and DOTA (1,4,7,10tetraazacyclododecane-1,4,7,10-tetraacetic acid) as metal-chelates, and Gd(III) complexes 45-60 based on them [57] (Figure 13).

The affinity of the coordination compounds 45-60 for amyloid aggregates was determined in vitro using $\left[{ }^{125} \mathrm{I}\right] \mathrm{IMPY}\left(\left[{ }^{125} \mathrm{I}\right] 6\right.$-iodo-2-(40-dimethylamino)-phenyl-imidazo [1,2-a]pyridine)-binding 
competition experiments on synthetic $A \beta_{1-42}$ aggregates, with DOTA-(Lys) $)_{3}$-BTA being the most potent. To assess the BBB permeability of the coordination compounds, an in vitro model of BBB constituted of a co-culture of rat primary brain capillary endothelial cells and rat glial cells was used. Unfortunately, none of the designed complexes showed BBB penetration ability.

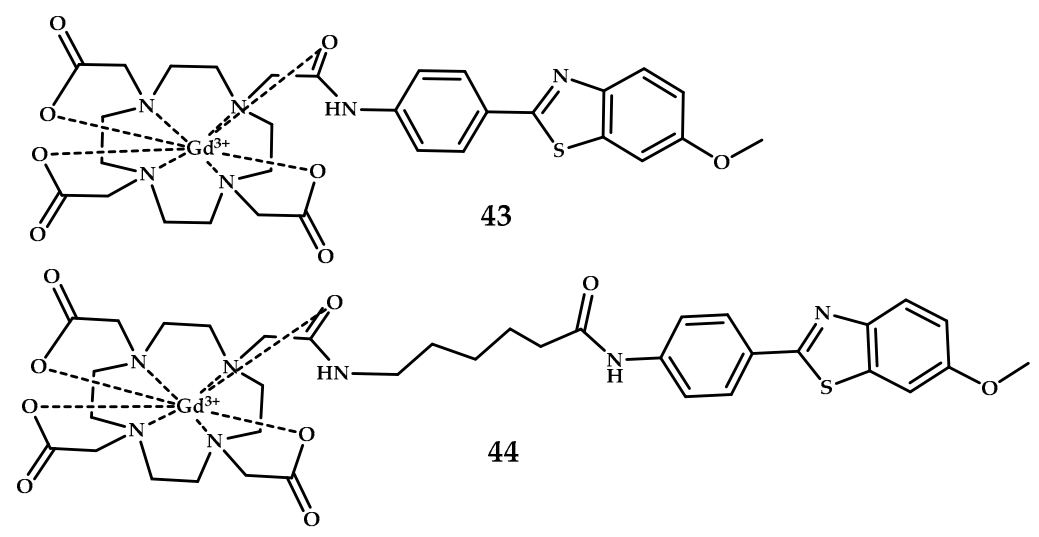

Figure 12. DO3A-PiB-based $\mathrm{Gd}^{3+}$ coordination compounds 43 and 44 , designed for MRI visualization of $\mathrm{A} \beta$ plagues.

Watanabe et al. designed and synthesized ${ }^{68}$ Ga-labeled benzofuran derivative 61 with 1,4,7,10-tetraazacyclododecane-1,4,7,10-tetraacetic acid (DOTA) as the metal-chelating agent [58] (Figure 14). A competitive $\mathrm{A} \beta_{1-42}$ binding experiment of $\mathbf{6 1}$ (with [ $\left.{ }^{125} \mathrm{I}\right]$ (IMPY) as the competitive ligand) showed a dose-dependent inhibition and values close to the clinically applied IMPY. Neuropathological fluorescent staining of Tg2576 mice brain sections treated with coordination compound 61 with Thioflavin $S$ as a control proved a specific binding of the coordination compound to $A \beta$ plaques. A biodistribution experiment in normal mice showed brain uptake of the coordination compound $\mathbf{6 1}$ $(0.45 \% \mathrm{ID} / \mathrm{g})$, which is too low for the compound to serve as an MRI agent.

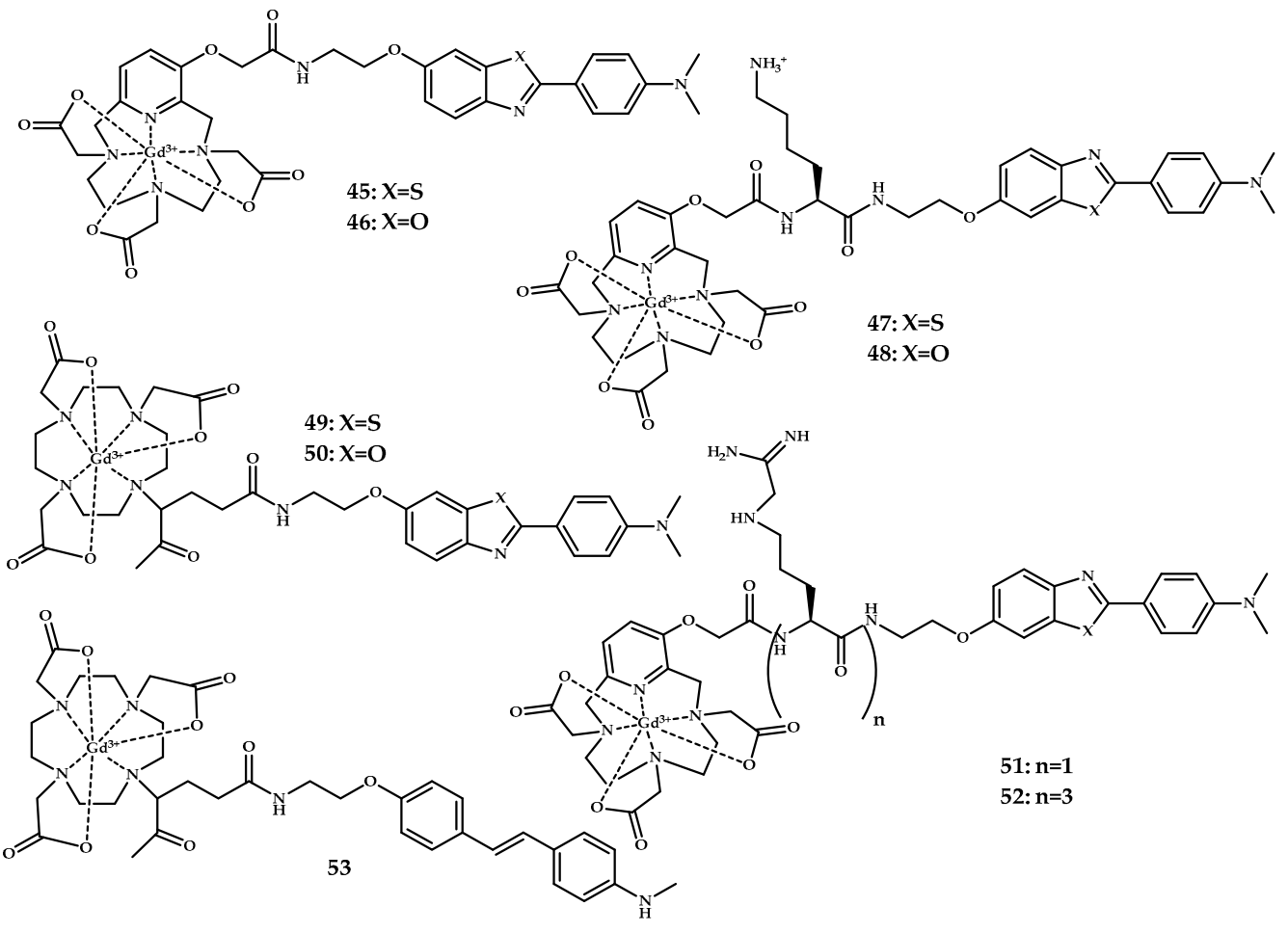

Figure 13. Cont. 


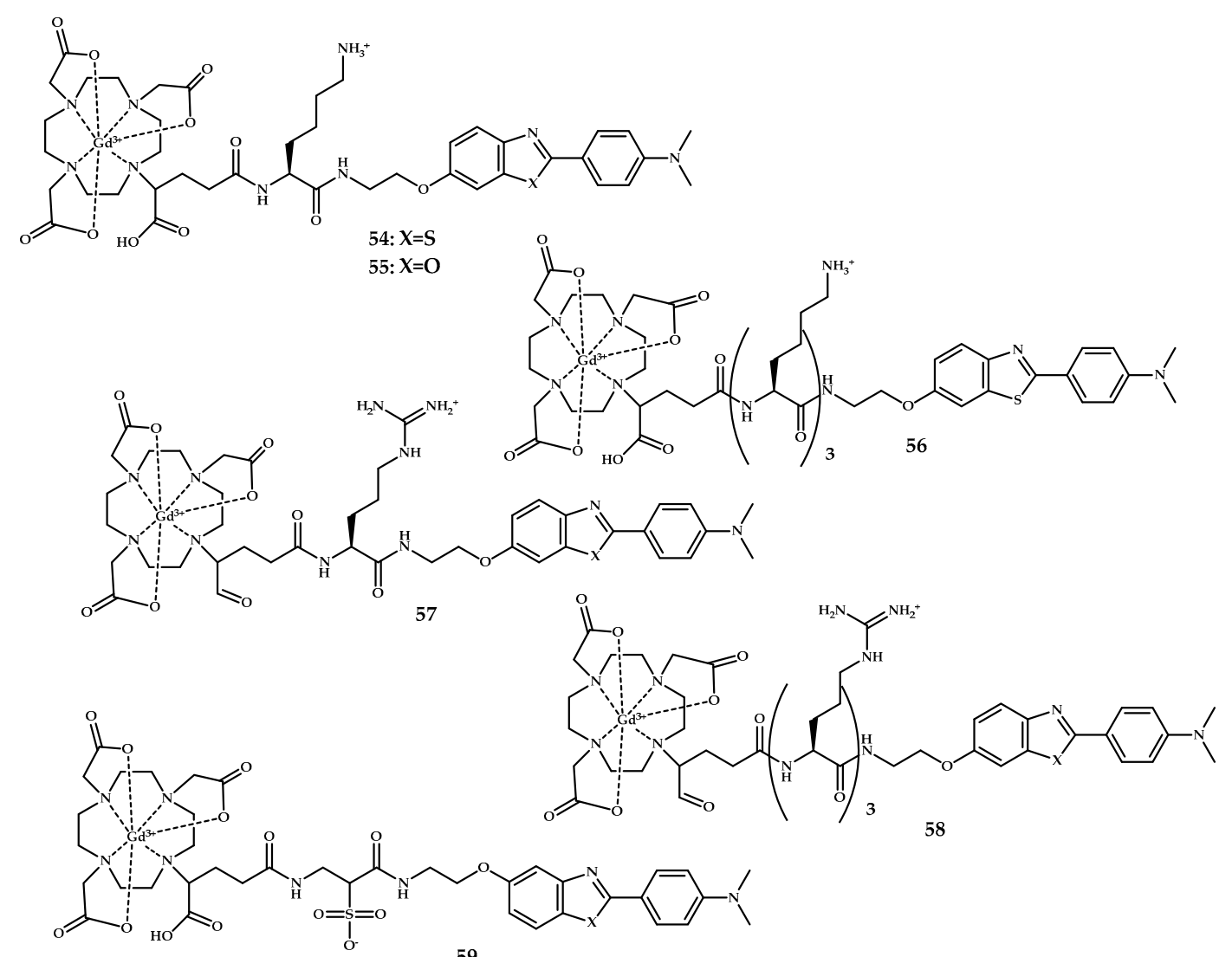

59

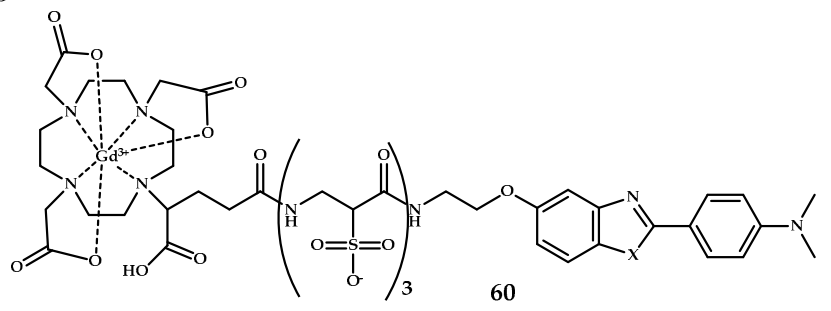

Figure 13. PCTA/DOTA-benzothiazole/benzoxazole/stilbene-based $\mathrm{Gd}^{3+}$ coordination compounds 45-60 designed for MRI visualization of $A \beta$ plagues.

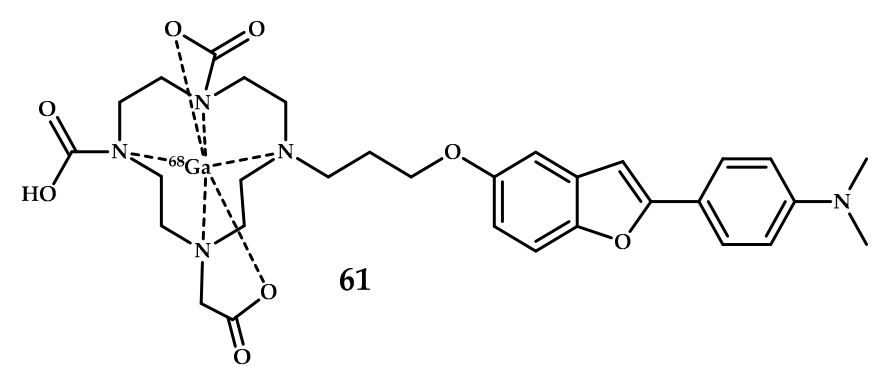

Figure 14. DOTA-benzofuran-based $\mathrm{Gd}^{3+}$ coordination compound $\mathbf{6 1}$ designed for MRI visualization of $\mathrm{A} \beta$ plagues.

Cressier et al. reported ${ }^{68}$ Ga-labeled complexes conjugated to Pittsburgh Compound B, 2-(4'-[ $\left.{ }^{11} \mathrm{C}\right]$ methylaminophenyl)-6-hydroxybenzothiazole (PIB) and DOTA via aromatic or alkyl pacers L62-L64 [59] (Figure 15). The BBB permeability of the complexes was insufficient, as shown by $\mu$ PET. Moreover, the evaluation of the complexes 62-64 through an autoradiographic approach with human brain tissues failed to detect amyloid deposits. 


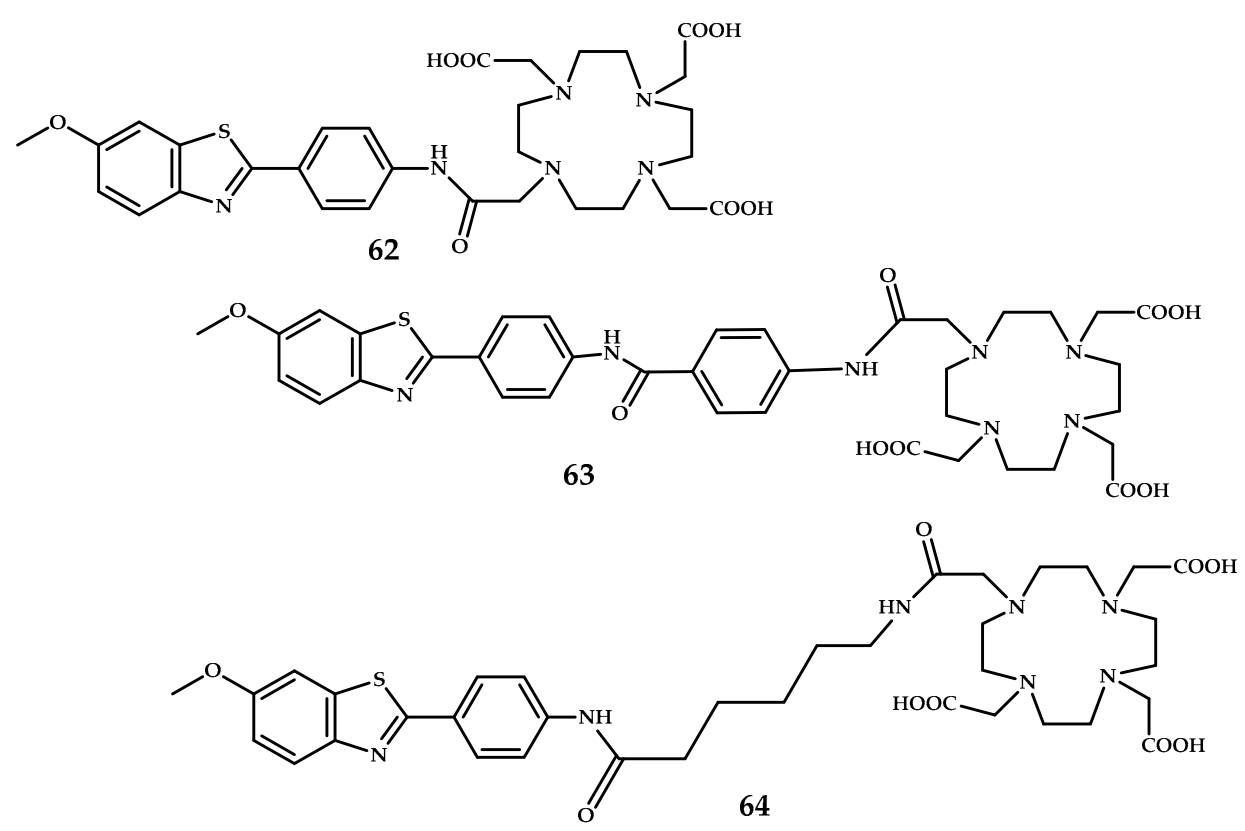

Figure 15. DOTA-Pib-based ligands L62-L64.

Zha et al. reported ${ }^{68} \mathrm{Ga}$-labeled styrylpyridine derivatives $65-70$ with high MW based on an $\mathrm{N}, \mathrm{N}^{\prime}$-bis[2-hydroxy-5-(carboxyethyl)benzyl]ethylenediamine-N,N'-diacetic acid (HBED-CC) core for $\mathrm{Ga}^{3+}$ complexation derivatized with styrylpyridinyl groups [60] (Figure 16). An in vitro competitive binding assay was conducted to measure the inhibition of [ $\left.{ }^{125} \mathrm{I}\right] \mathrm{IMPY} \mathrm{A} \beta$ binding by coordination compounds 65-70. The monovalent conjugate 69 showed a low binding affinity. The in vitro autoradiography on $\mathrm{AD}$ brain sections showed a high binding affinity of 65-70 to $\mathrm{A} \beta$ plaques, but in vivo biodistribution studies in CD-1 mice showed low brain penetration. This may allow a selective labeling of $A \beta$ plaques deposited on the walls of cerebral blood vessels, which could be a useful tool for diagnosing cerebral amyloid angiopathy (CAA), but not in the $A \beta$ plaques in the parenchymal brain tissues.

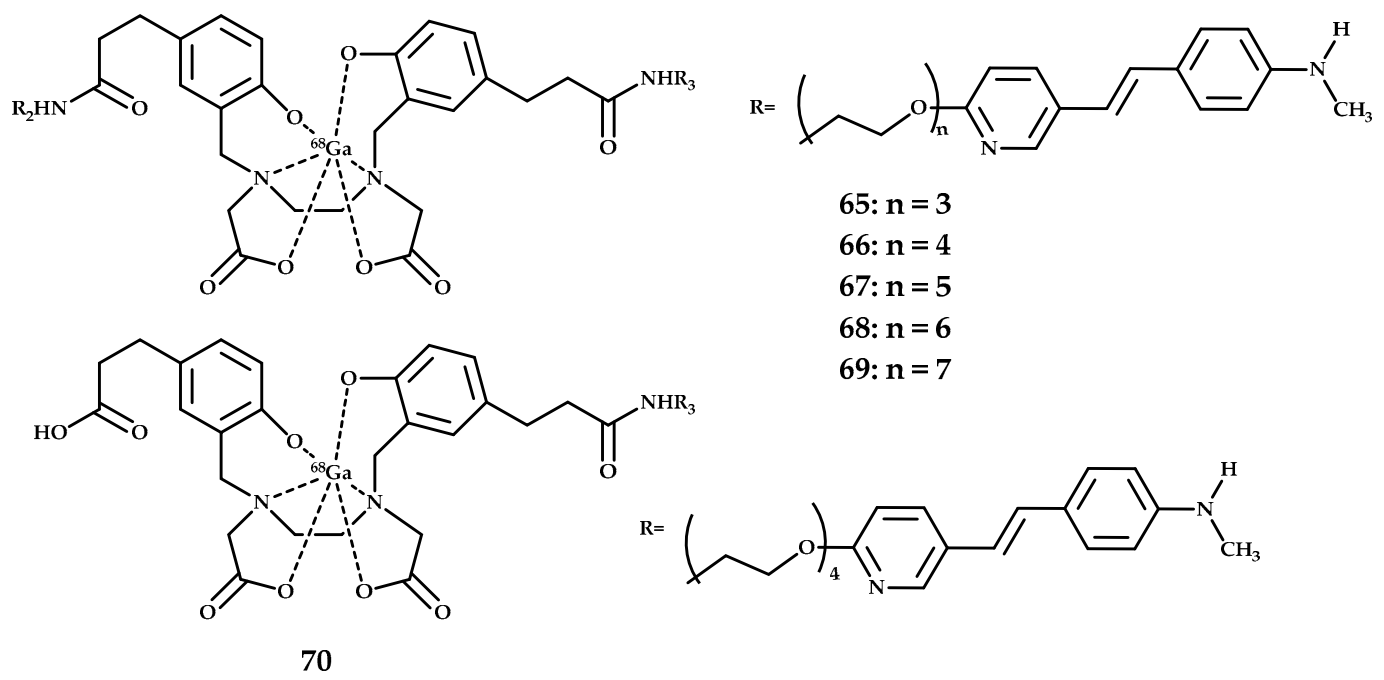

Figure 16. HBED-CC-styrilpiridine coordination compounds 65-70, designed for PET imaging of $\mathrm{A} \beta$ plaques.

Curcumin (C21), (1E,6E)-1,7-bis(4-hydroxy-3-methoxyphenyl)-1,6-heptadiene-3,5-dione, is a promising organic motif for designing biologically active coordination compounds. 
Curcumin demonstrated high antiproliferative activity in vitro and in vivo [67] and is also known to accumulate in tumor cells, presumably due to the ability to bind the vitamin-D receptor [68].

Curcumin and its derivatives are widely studied as agents for diagnosis, prevention, and treatment of $\mathrm{AD}[69,70]$, and also proved to be an amyloid-specific dye [71,72]. It binds to soluble A $\beta$ plagues [73] and is reported to have sufficient brain permeability and favorable amyloid-binding in APPsw Tg-mice [74]. Curcumin is currently regarded as a specific organic core for AD therapy and diagnostic drug development. Several curcumin-based fluorescent probes for $\mathrm{A} \beta$ imaging have been designed [75]. A number of research works are devoted to a curcumin-based metal-containing agent for MRI, SPECT, and PET diagnostics [76].

The affinity of curcumin for amyloid plaques has raised interest in chalcone derivatives as organic core for the development of $A \beta$-affinity diagnostic agents. In 2007, Ono et al. reported chalcone-based probes for in vivo imaging of $A \beta$ plaques in Alzheimer's brains [77]. Chauhan et al. reported a bis-chalcone $\mathrm{Ga}^{3+}$-based coordination compound 71 [61] (Figure 17). The stability of coordination compound 69 in HSA was proven using ITLC-SG. Also, the high A $\beta$-binding affinity of 69 to HAS was proven in a protein-binding assay. $A \beta$-binding studies on aggregated $A \beta_{42}$ were performed, and Scatchard plots suggest one-site binding with a $K_{d}$ of $3.46 \pm 0.41 \mathrm{nM}$.

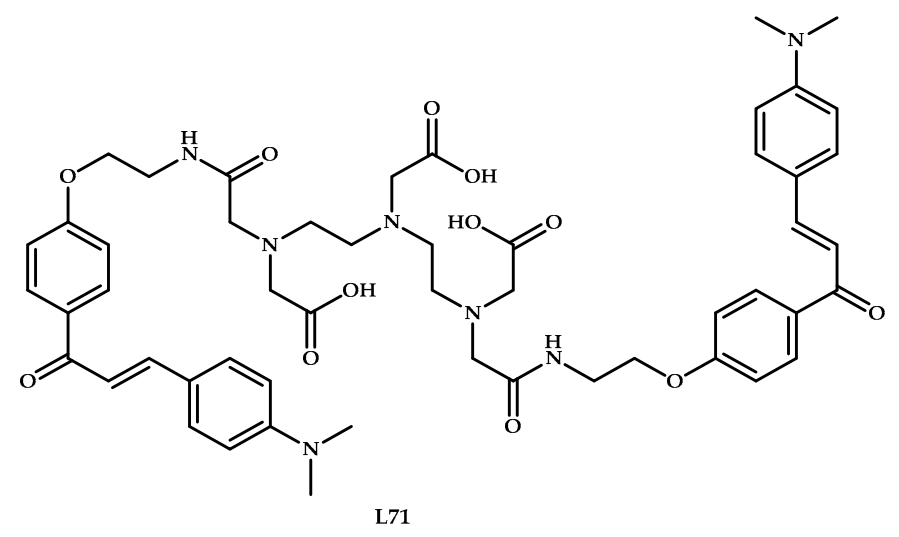

Figure 17. Chalchone-based ligand L71, designed for $\mathrm{A} \beta$ plaques binding.

Blood kinetics studies of coordination compound $\mathbf{7 1}$ in normal rabbits showed a fast clearance during the initial time period of $30 \mathrm{~min}$. Biodistribution studies showed a high uptake level of $1.24 \% \pm 0.31 \%$ with rapid excretion within an hour. Also, PET images in a normal adult male BALB/C mice during 2-30 m intravenous post-injection exhibited a significant activity in the brain at $2 \mathrm{~min}$ post-injection and rapid washout from the healthy brain. Thus, coordination compound $\mathbf{7 1}$ showed no specific binding or prolonged retention in the healthy brain, due to the absence of $A \beta$ plagues.

Asti et al. reported ${ }^{68} \mathrm{Ga}$-labeled complexes based on curcumin, diacetyl-curcumin (DAC), and bis(dehydroxy)curcumin (bDHC) 72-74 [62] (Figure 18). The affinity of nat $/{ }^{68} \mathrm{Ga}$-Curcuminoid complexes 72-74 for $A \beta_{1-40}$ amyloid synthetic fibrils was evaluated by measuring the radioactivity of synthetic $A \beta$ fibrils preincubated with complexes 72-74 and also using fluorescence microscopy with untreated fibrils as a negative control. A fluorescence microscopy study of drug-preincubated A-549 tumor cells confirmed an internalization of $\mathrm{Ga}^{3+}$-curcuminoid complexes in lung cancer cells.

Continuing the study, Rubagotti et al. reported [63] an in vitro and in vivo investigation of the biological properties of coordination compounds 72-74. The in vivo brain uptake was assessed using a Tg2576 mice model. Although $A \beta$ plagues were clearly visualized after brain section staining with coordination compounds, no brain uptake in vivo was observed. These results indicate a high $A \beta$-affinity of gallium complexes 72-74 along with an inability of the coordination compounds to cross the BBB in vivo.

Lange et al. reported [64] a six-coordinate $\mathrm{Ga}^{3+}$ complex 75 based on an $\mathrm{N}_{2} \mathrm{O}_{2}$ Schiff-base ligand and $\beta$-diketone curcumin, which is known to bind to $A \beta$ plagues because of the structural similarity to 
Congo Red [78] (Figure 19). The ability of 75 to bind to $A \beta$ plaques was assessed using epi-fluorescence microscopy $(\lambda \mathrm{ex}=359 \mathrm{~nm}$, $\lambda \mathrm{em}=461 \mathrm{~nm}$ ) on AD and age-matched human brain samples with an $1 \mathrm{E} 8$-antibody as control. The obtained results allow suggesting some degree of specificity of $\mathbf{7 3}$ for A $\beta$ plaques.

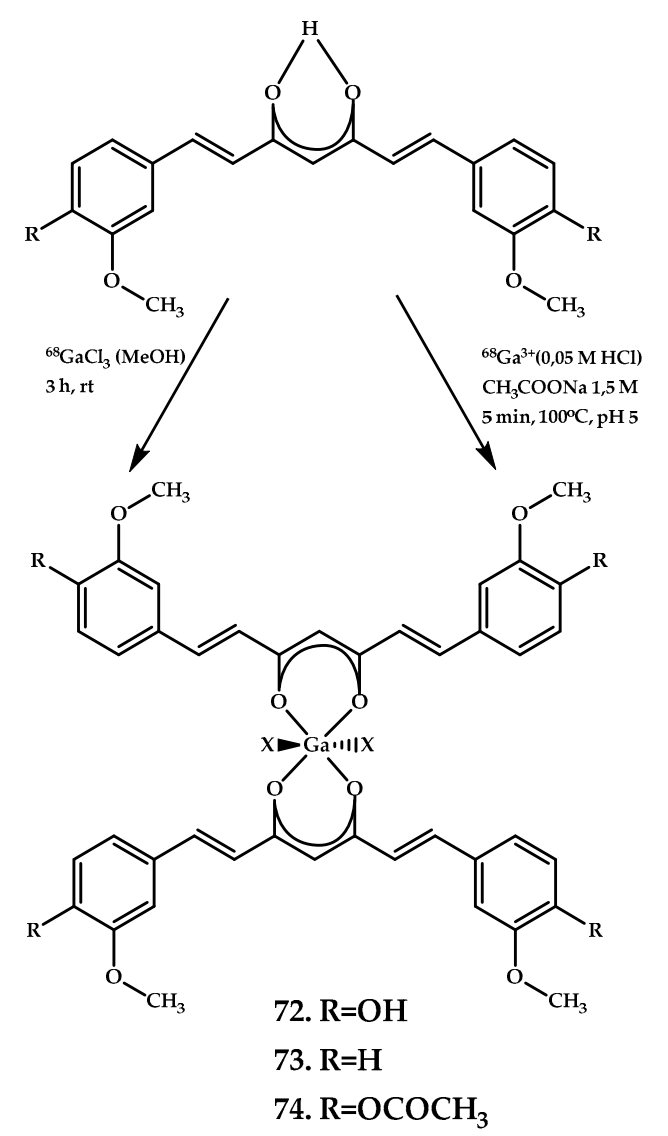

Figure 18. Curcumin-based $\mathrm{Ga}^{3+}$ coordination compounds 72-74, designed for PET imaging of $\mathrm{A} \beta$ plaques.

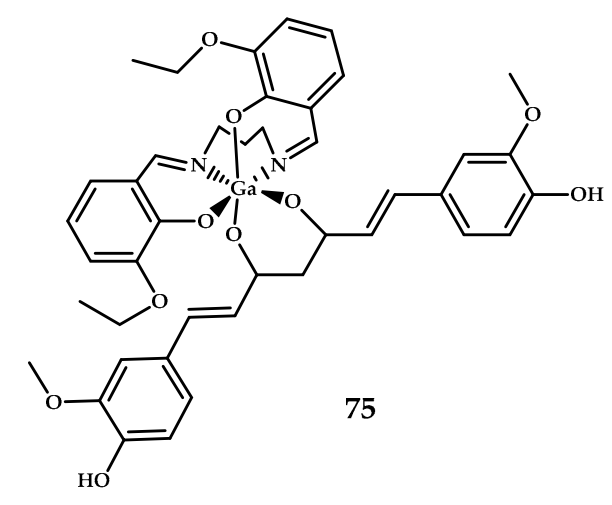

Figure 19. Curcumin-based $\mathrm{Ga}^{3+}$ coordination compound 75 with a Schiff-based metal-chelating moiety, designed for PET imaging of $A \beta$ plaques.

Orteca et al. recently reported curcumin scaffolds conjugated with 1,4,7triazacyclononane,1-glutaric acid-4,7-acetic acid (NODAGA) and 1,4-bis(carboxymethyl)-6[bis(carboxymethyl)]amino-6-methylperhydro-1,4-diazepine (AAZTA) as metal chelators L76 and L77 [65] (Figure 20). 


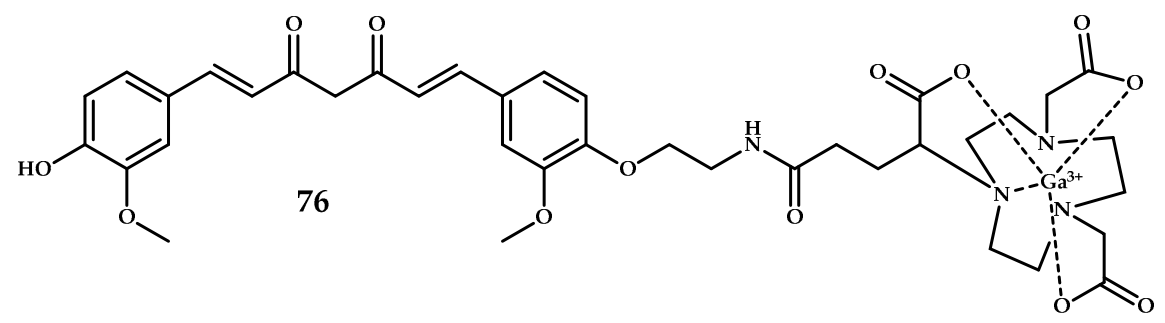

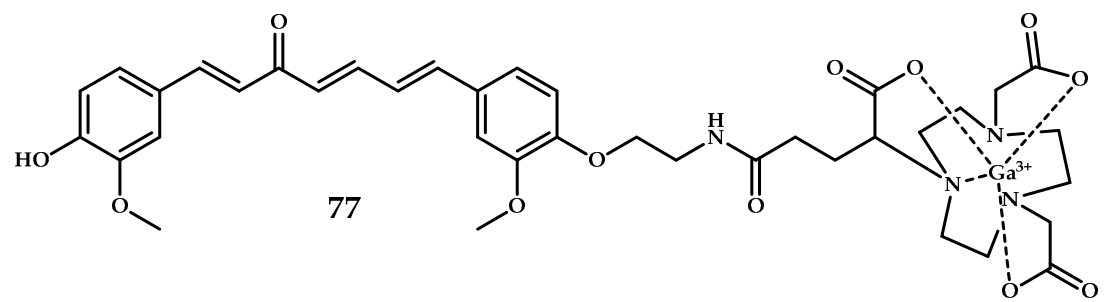

Figure 20. Curcumin-based $\mathrm{Ga}^{3+}$ coordination compounds 76 and 77 with NODAGA and AAZTA metal-chelating moieties, designed for PET imaging of $\mathrm{A} \beta$ plaques.

Gniazdowska et al. designed a series of tacrine analogues, acetylcholinesterase (AChE) and butyrylcholinesterase $(\mathrm{BuChE})$ inhibitor [79], the enzymes responsible for the degeneration of the neurotransmitter acetylcholine and labeled with diagnostic radionuclides technetium-99m using bifunctional ligand Hynic [80] 78-85, and gallium-68, using macrocyclic ligand DOTA 84-86 [80] (Figure 21). The Log D values for the coordination compounds are presented in Table 3. Coordination compounds $\mathbf{8 2}$ and $\mathbf{8 6}$ with the highest Log D values were selected as lead compounds.

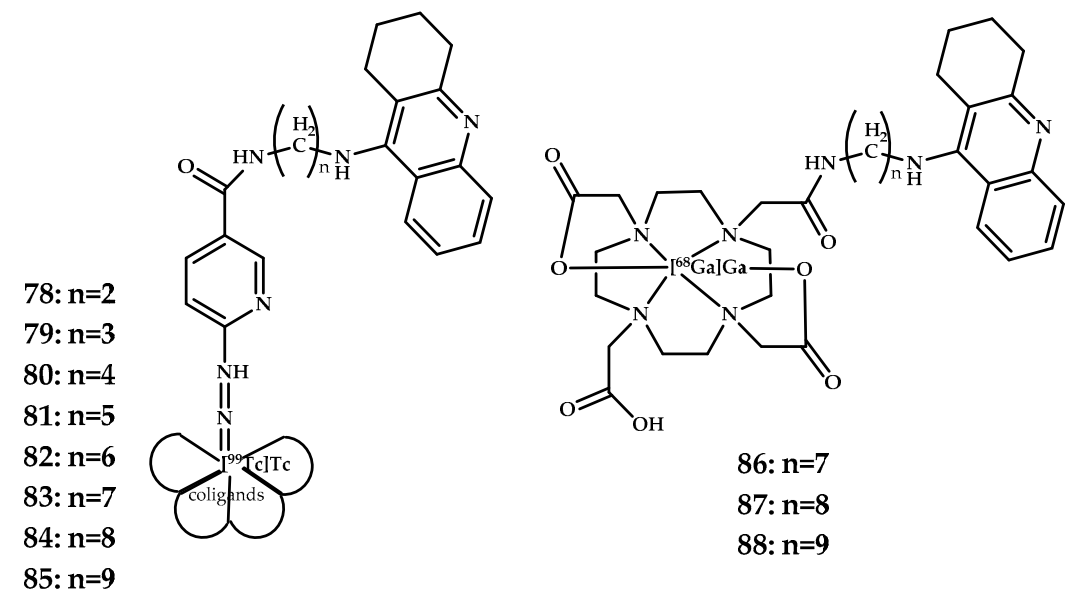

Figure 21. Tacrine-based ${ }^{99} \mathrm{Tc}^{3+}$ coordination compounds 78-85 and Ga ${ }^{3+}$ coordination compounds 86-88 with Hynic and DOTA metal-chelating moieties, designed for PET imaging of A $\beta$ plaques.

Table 3. Log D values for coordination compounds 78-88.

\begin{tabular}{|c|c|c|c|}
\hline$\left(\mathrm{CH}_{2}\right)_{\mathrm{n}}$ & $\log D$ & & \\
\hline & {$\left[{ }^{99 m} \mathrm{Tc}\right] \mathrm{Tc}-\mathrm{Hynic}-\mathrm{NH}\left(\mathrm{CH}_{2}\right)_{n} \mathrm{Tac}$} & & {$\left[{ }^{68} \mathrm{Ga}\right] \mathrm{Ga}-\mathrm{DOTA}-\mathrm{NH}\left(\mathrm{CH}_{2}\right)_{\mathrm{n}} \mathrm{Tac}$} \\
\hline 78: $n=2$ & $-2.95 \pm 0.06$ & & - \\
\hline 79: $n=3$ & $-2.80 \pm 0.01$ & & - \\
\hline 80: $n=4$ & $-2.53 \pm 0.02$ & & - \\
\hline 81: $n=5$ & $-2.41 \pm 0.01$ & & - \\
\hline 82: $n=6$ & $-2.08 \pm 0.01$ & & - \\
\hline 83: $n=7$ & $-1.86 \pm 0.02$ & 86: & $-2.52 \pm 0.01$ \\
\hline 84: $n=8$ & $-1.50 \pm 0.01$ & 87: & $-2.02 \pm 0.01$ \\
\hline 85: $n=9$ & $-1.38 \pm 0.01$ & 88: & $-1.52 \pm 0.01$ \\
\hline
\end{tabular}


An ability of coordination compounds 82 and 86 to inhibit acetylcholinesterase (AChE) and butyrylcholinesterase (BuChE) was estimated using Ellman's colorimetric assay. The half maximal inhibitory concentration $\mathrm{IC}_{50}$ values for the tested derivatives are presented in Table 4 . Tacrine was used as the reference inhibitor.

Table 4. The activity of 82 and 86 against two cholinesterases.

\begin{tabular}{|c|c|c|c|c|}
\hline \multirow{2}{*}{ Compound } & \multicolumn{2}{|c|}{$\mathrm{IC}_{50} \pm \mathrm{SD}^{* *}(\mathrm{nM})$} & \multirow{2}{*}{$\begin{array}{l}\text { Selectivity for } \\
\operatorname{AChE}^{\mathrm{a}}\end{array}$} & \multirow{2}{*}{$\begin{array}{l}\text { Selectivity for } \\
\text { BuChE }^{\text {b }}\end{array}$} \\
\hline & AChE & BuChE & & \\
\hline 82 & $0.10 \pm 0.01$ & $0.12 \pm 0.02$ & 1.2 & 0.83 \\
\hline 86 & $290 \pm 20$ & $167 \pm 9$ & 0.57 & 1.75 \\
\hline Tacrine & $107 \pm 9$ & $16 \pm 1$ & 0.15 & 6.67 \\
\hline
\end{tabular}

a Selectivity for $\mathrm{AChE}$ is defined as $\mathrm{IC}_{50}(\mathrm{BuChE}) / \mathrm{IC}_{50}(\mathrm{AChE})$; ${ }^{\mathrm{b}}$ Selectivity for $\mathrm{BuChE}$ is defined as $\mathrm{IC}_{50}(\mathrm{AChE}) / \mathrm{IC}_{50}(\mathrm{BuChE}){ }^{* *}$ half maximal inhibitory concentrations \pm standard deviation

An in vivo pharmacodynamic study of coordination compound 86 allowed only a qualitative view because the brain penetration was low, $0.21 \%$. The pharmacodynamic study of coordination compound 82 was incomplete due to the low activity of the compound, and the result was therefore omitted. But the ex vivo radioactivity measurement showed that both complexes can penetrate the BBB.

\section{4. ${ }^{99} \mathrm{Tc}^{3+}$-Based Coordination Compounds for SPECT Visualization of $\mathrm{A} \beta$}

To overcome the limitations of PET imaging in terms of cost and broad accessibility, SPECT was proposed as alternative diagnostic tool [81]. Technetium- $99 \mathrm{~m}\left({ }^{99 \mathrm{~m}} \mathrm{Tc}\right)$ is a desirable radioisotope for the preparation of SPECT radiopharmaceuticals because it has a rich chemistry, unique nuclear properties $\left(\mathrm{T}_{1 / 2}=6 \mathrm{~h}, \mathrm{E}=140 \mathrm{keV}\right)$, and an easy cost-effective availability. ${ }^{99 \mathrm{~m}} \mathrm{Tc}$ can be readily prepared by a ${ }^{99} \mathrm{Mo} /{ }^{99 \mathrm{~m}} \mathrm{Tc}$ generator [82]. The development of a ${ }^{99 \mathrm{~m}} \mathrm{Tc}$-radiotracer for imaging $\mathrm{A} \beta$ plaques with SPECT is strongly expected to provide a low cost, broadly accessible diagnostic tool for AD. Table 5 summarizes the coordination compounds for single-photon emission computed tomography (SPECT) diagnostics of Alzheimer's disease:

Table 5. ${ }^{99 \mathrm{~m}} \mathrm{Tc}$ coordination compounds for single-photon emission computed tomography (SPECT) visualization of AD.

\begin{tabular}{|c|c|c|c|c|c|}
\hline № & $\begin{array}{l}\text { Brain Uptake, ID/g, } 2 \\
\text { Min Post-Injection \% }\end{array}$ & 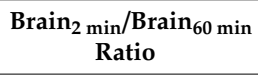 & Brain Tissue Experiments & Ligand & Reference \\
\hline 89-91 & $\begin{array}{l}4.10 \pm 0.38 \\
/ 6.34 \pm 0.81 \\
2.30 \pm 0.27 \\
/ 3.68 \pm 0.07 \\
\\
1.11 \pm 0.34 / \\
1.64 \pm 0.17 \\
\\
\text { With/without PgP } \\
\text { Blocked by } \\
\text { Cyclosporin A }\end{array}$ & $\begin{array}{l}8.20 \\
4.18 \\
1.73\end{array}$ & $\begin{array}{l}\text { Fluorescent staining of Re } \\
\text { complexes on } \\
\text { APPswe/PSEN1 mice and AD } \\
\text { patient brain sections } \\
\text { Autoradiography on a } \\
\text { APPswe/PSEN1 model mice }\end{array}$ & $\begin{array}{l}\text { Chalcone-mimic moiety } \\
\text { with }\left[\mathrm{Cp}^{99 \mathrm{~m}} \mathrm{Tc}(\mathrm{CO})_{3}\right]\end{array}$ & [83] \\
\hline 92-95 & $\begin{array}{l}0.49 \pm 0.08 \\
0.47 \pm 0.11 \\
0.48 \pm 0.06 \\
0.31 \pm 0.06\end{array}$ & $\begin{array}{l}6.13 \\
3.92 \\
5.33 \\
2.06\end{array}$ & $\begin{array}{l}\text { In vitro fluorescent staining } \\
\text { of Re complexes of brain } \\
\text { tissue } A P P \text { Swe/PSEN1 mice }\end{array}$ & $\begin{array}{l}\text { Curcumin-like } \\
\text { dibenzylideneacetone } \\
\text { conjugated with } \\
\text { monoamineemonoamide } \\
\text { dithiol (MAMA) and BAT } \\
\text { (bis(aminoethanethiol) as } \\
\text { chelating moieties }\end{array}$ & [84] \\
\hline $96-100$ & $0.28 \pm 0.03$ & 2.54 & $\begin{array}{l}\text { Autoradiography } T g 2576 \\
\text { and wild-type mice }\end{array}$ & $\begin{array}{l}\text { Benzotiasole/stilbene } \\
\text { conjugated with } \\
\text { hydroxamamide (Ham) as } \\
\text { chelating moiety }\end{array}$ & {$[85,86]$} \\
\hline
\end{tabular}


Table 5. Cont.

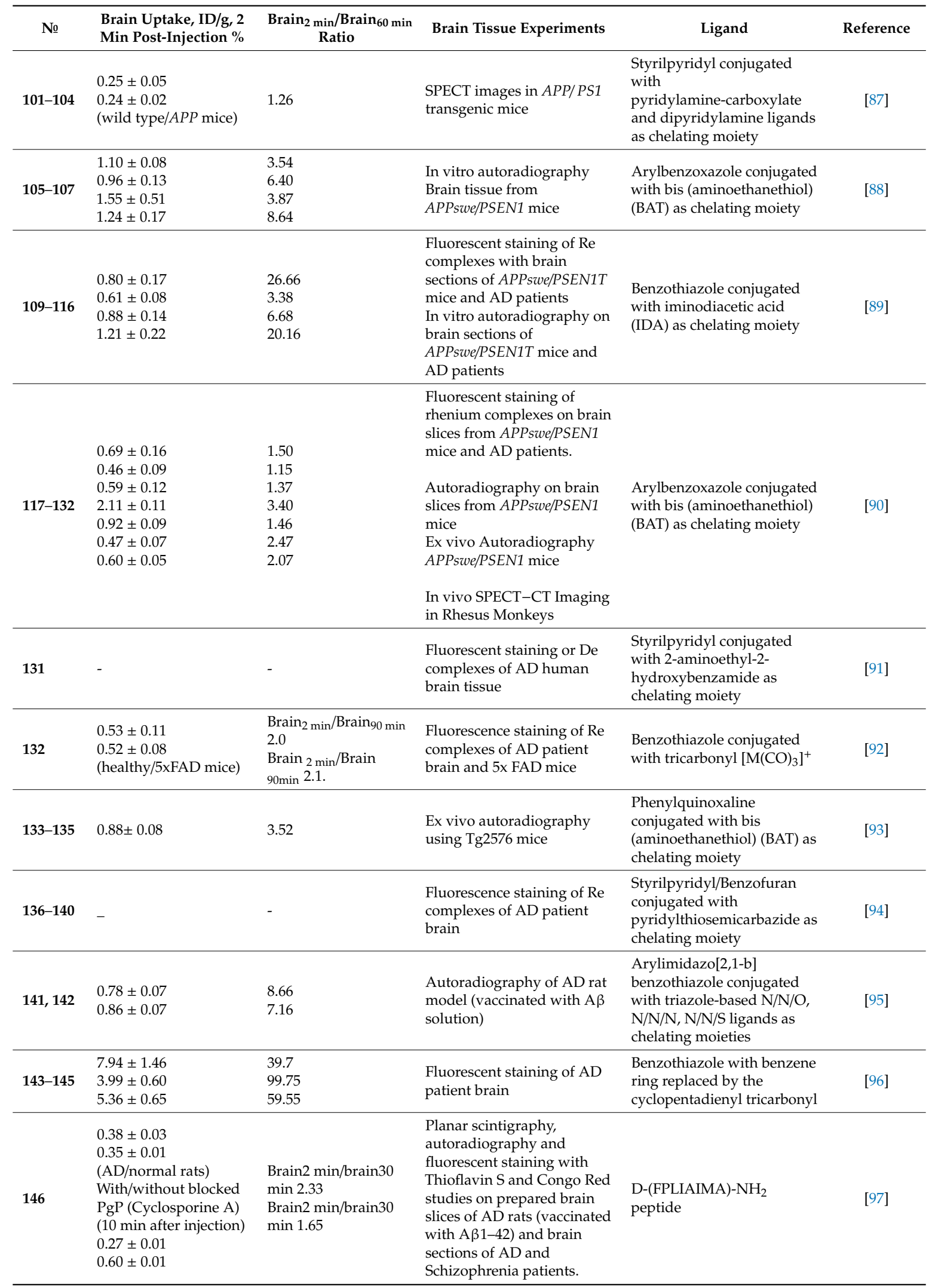

Liu et al. designed and synthesized novel chalcone-mimic Re $/{ }^{99 \mathrm{~m}} \mathrm{Tc}$ Re-89-91/[99m $\left.\mathrm{Tc}\right] \mathbf{8 7 - 9 1}$ complexes [83] (Figure 22). Ferrocene complexes were synthesized as precursors for ${ }^{99} \mathrm{~m}$ Tc coordination 
compounds. Complexes Re-90 and Re-91 demonstrated a high affinity to A $\beta$ plaques in brain tissue sections from $\mathrm{AD}$ patients and Tg-mice (APPswe/PSEN1), while demonstrating no apparent labeling in both normal mice C57BL6 and normal adult brain sections. The $\mathrm{K}_{\mathrm{i}}$ value ranges established using an $\mathrm{A} \beta_{1-42}$ binding assay ranged from 899 to $108 \mathrm{nM}$. As an extension of the conjugated $\pi$ system, complex Re-91 demonstrated the highest affinity. The in vitro autoradiography of $\left[{ }^{99 \mathrm{~m}} \mathrm{Tc}\right] 89-91$ on Tg-mice brains confirmed the $\mathrm{A} \beta$ affinity of $\left[{ }^{99 \mathrm{~m}} \mathrm{Tc}\right] 91(\mathrm{Ki}=108 \mathrm{nM})$. In the biodistribution studies, $\left[{ }^{99 \mathrm{~m}} \mathrm{Tc}\right] 89$ and $\left[{ }^{99 \mathrm{~m}} \mathrm{Tc}\right] 90$ showed excellent initial uptakes and fast clearance (respectively $4.10 \%$ and $2.30 \%)$ in the brain, while [ $\left.{ }^{99 m} \mathrm{Tc}\right] 91$ showed moderate brain uptake $(1.11 \%)$.

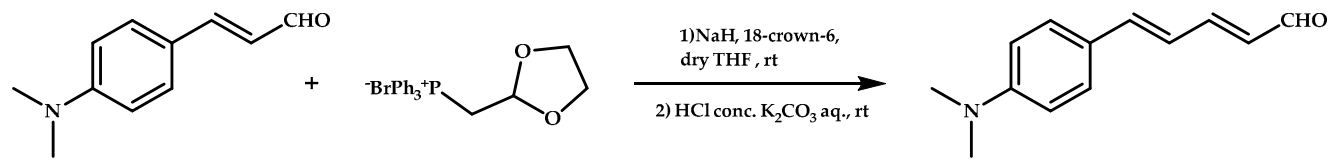

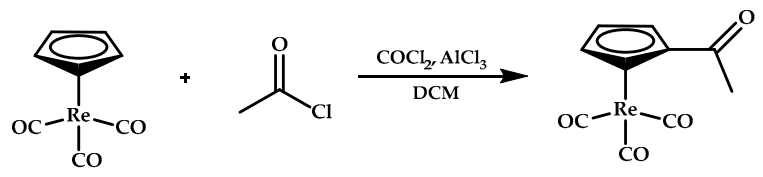

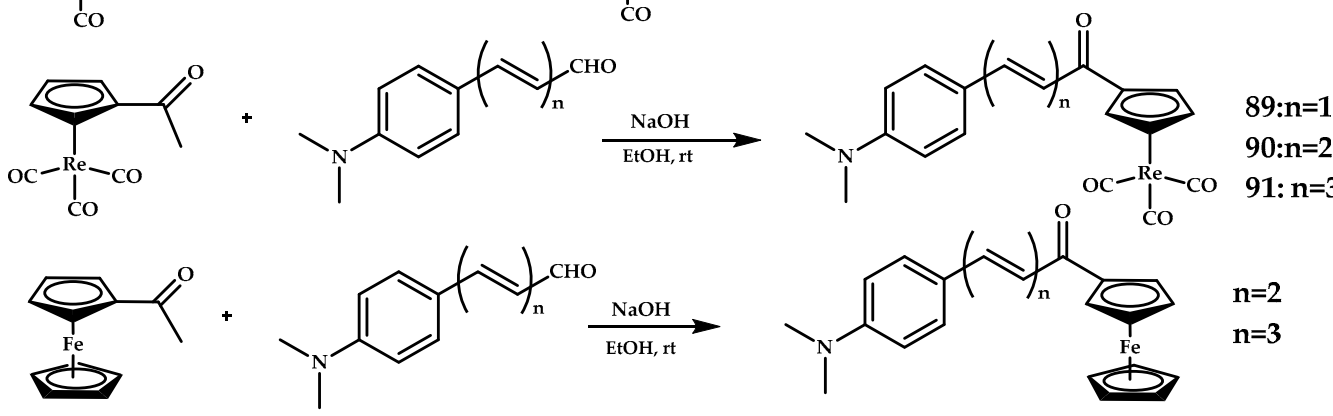

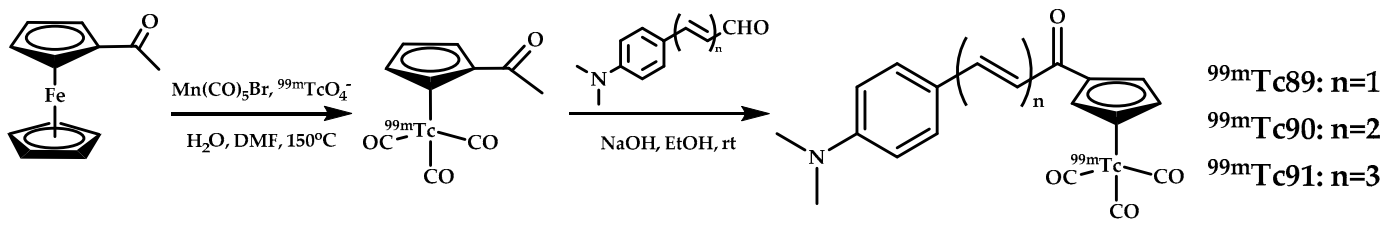

Figure 22. $\left[{ }^{99 \mathrm{~m}} \mathrm{Tc}\right]$ coordination compounds [ $\left.{ }^{99 \mathrm{~m}} \mathrm{Tc}\right] \mathbf{8 9 - 9 1}$ based on chalchone-mimic scaffolds and their Re analogues 89-91.

A biodistribution in permeability-glycoprotein blocked by cyclosporin A (an immunosuppressant drug) revealed an increase of BBB-penetrating abilities of the coordination compounds [ $\left.{ }^{\mathbf{9 9}} \mathrm{Tc}\right] \mathbf{8 9 - 9 1 .}$ This result may reveal $\left[{ }^{99 m} \mathrm{Tc}\right] \mathbf{8 9 - 9 1}$ to be substrates for the rodent PgP transporter.

Yang et al. reported four ${ }^{99 \mathrm{~m}} \mathrm{Tc}$-labeled dibenzylideneacetone derivatives $\left[{ }^{99 \mathrm{~m}} \mathrm{Tc}\right] \mathbf{9 2 - 9 5}$ and corresponding rhenium complexes 92-95 [84] (Figure 23).

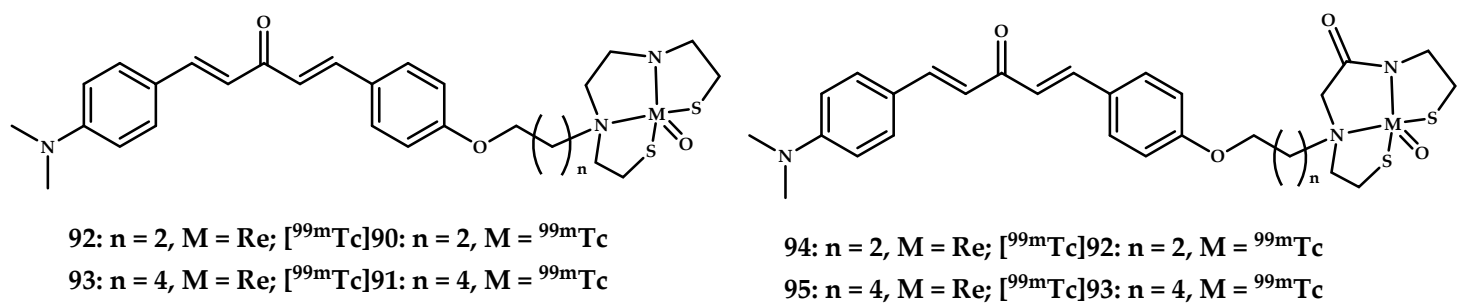

Figure 23. Coordination compounds Re/ ${ }^{99 \mathrm{~m}} \mathrm{Tc}$ 92-95 based on dibenzylideneacetone scaffolds with BAT $\left(92,93 /\left[{ }^{99 m} \mathrm{Tc}\right] 92,\left[{ }^{99 m} \mathrm{Tc}\right] 93\right)$ and MAMA $\left(94,95 /\left[{ }^{99 m} \mathrm{Tc}\right] 94,\left[{ }^{99 m} \mathrm{Tc}\right] 95\right)$ designed for SPECT imaging of A $\beta$ plaques. 
The binding affinities of rhenium complexes $92-95$ for $A \beta_{1-42}$ aggregates were evaluated by competition binding assay using $\left[{ }^{125} \mathrm{I}\right] \mathrm{IMPY}$. Coordination compounds 92 and 93 with the BAT chelating moiety showed better $A \beta_{1-42}$ affinity $\left(K_{i}=24.7\right.$ and $\left.13.6 \mathrm{nM}\right)$ compared with coordination compounds 94 and 95 with the MAMA chelating moiety $\left(K_{i}=120.9\right.$ and $\left.59.1 \mathrm{nM}\right)$. Increasing the length of the spacer was found to promote $A \beta_{1-42}$ binding. All four rhenium complexes, 92-95, displayed excellent labeling of $\mathrm{A} \beta$ plaques in in vitro fluorescent staining on sections of brain tissue from a Tg-mice (C57BL6, APPswe/PSEN1) and age-matched control mice. Biodistribution experiments of ${ }^{99 \mathrm{~m}}$ Tc-labeled coordination compounds [ $\left.{ }^{99 \mathrm{~m}} \mathrm{Tc}\right] \mathbf{9 2 - 9 5}$ in normal ICR mice showed the highest initial uptake at $2 \mathrm{~min}$ post-injection (respectively $0.49 \%, 0.47 \%, 0.48 \%$, and $0.31 \% \mathrm{ID} / \mathrm{g}$ ), followed by rapid washout from the brain.

Iikuni et al. designed five novel ${ }^{99 \mathrm{~m}} \mathrm{Tc}-\mathrm{Ham}$ complexes $\left[{ }^{99 \mathrm{~m}} \mathrm{Tc}\right] \mathbf{9 6}-99$ with a bivalent amyloid ligand based on stilbene/benzothiazole moieties and HAM as chelating agent [85] (Figure 24).

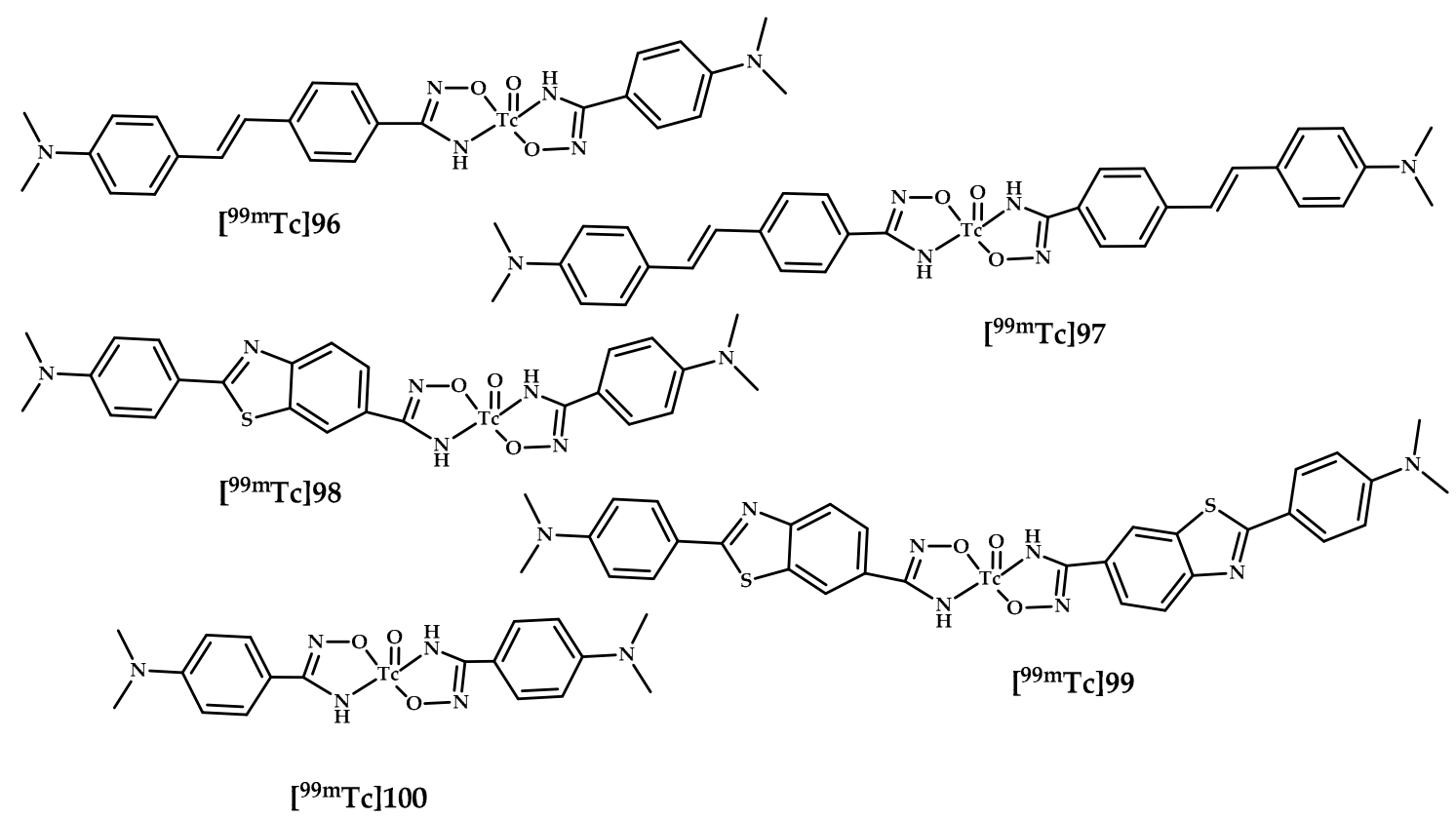

Figure 24. ${ }^{99} \mathrm{~m}$ Tc-HAM complexes based on stilbene and benzothiazole moieties [ $\left.{ }^{99 m} \mathrm{Tc}\right] \mathbf{9 6}-\mathbf{9 9}$, designed for SPECT imaging of A $\beta$ plaques, and model coordination compound 100.

Coordination compounds [ $\left.{ }^{99 \mathrm{~m}} \mathbf{T c}\right] \mathbf{9 6}-99$ displayed moderate affinity for amyloid aggregates (respectively $22.2 \%, 42.6 \%, 4.6 \%, 38.7 \%$ ), while model compound [ $\left.{ }^{99 \mathrm{~m}} \mathrm{Tc}\right] 100$, which does not include any amyloid ligands, showed no affinity. In vitro autoradiography of Tg2576 mice brain section assay proved an ability of [ $\left.{ }^{99 \mathrm{~m}} \mathrm{Tc}\right] 96,\left[{ }^{99 \mathrm{~m}} \mathrm{Tc}\right] 97$, and $\left[{ }^{99 \mathrm{~m}} \mathrm{Tc}\right] 99$ to bind $\mathrm{A} \beta$ plaques. A biodistribution experiment of $\left[{ }^{99 \mathrm{~m}} \mathrm{Tc}\right] 97$ with the highest binding affinity in the inhibition assay in normal mice showed very low brain uptake $(0.28 \% \mathrm{ID} / \mathrm{g})$.

Further, the authors of Reference [86] applied coordination compounds [ $\left.{ }^{99 m} \mathrm{Tc}\right] \mathbf{9 6}-\mathbf{9 9}$ to CAA-specific imaging probes and evaluated their utility for CAA-specific imaging. An in vitro inhibition assay using $A \beta_{1-40}$ aggregates deposited mainly in CAA showed a high binding affinity of coordination compounds [ $\left.{ }^{99 \mathrm{~m}} \mathrm{Tc}\right] 96-99$. In vitro autoradiography of human CAA brain sections and ex vivo autoradiography of $\operatorname{Tg} 2576$ mice displayed excellent labeling of $A \beta$ depositions in human CAA brain sections and high affinity and selectivity to CAA in Tg-mice of coordination compounds $\left[{ }^{99 \mathrm{~m}} \mathrm{Tc}\right] 97$ and $\left[{ }^{99 \mathrm{~m}} \mathrm{Tc}\right] 99$.

Hayne et al. reported [87] tridentate ligands L101-L104 designed to bind to the $\left[\mathrm{M}(\mathrm{CO})_{3}\right]^{+}$core $(\mathrm{M}=\mathrm{Tc} / \mathrm{Re})$ conjugated with a stilbene $\mathrm{A} \beta$-binding moiety (Figure 25). The complexes 101 and 103 showed little to no plaque binding in brain tissue from AD-positive subjects. Epi-fluorescence 
microscopy of tissue sections of the frontal cortex of an AD-affected brain treated with $\mathbf{1 0 2}$ and 104 bearing an electron-donating dimethylamino functional group revealed good correlation of the complexes to $\mathrm{A} \beta$ plaques, and the E18 antibody was used as a control.

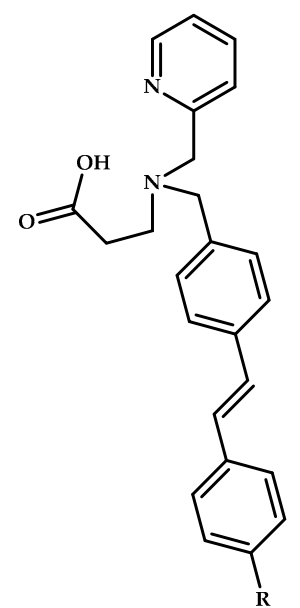

L101: $\mathrm{R}=\mathrm{H}$

L102: $\mathrm{R}=\mathrm{NMe}_{2}$

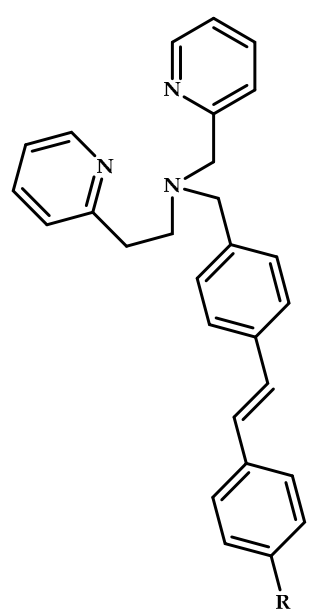

L103: $\mathrm{R}=\mathrm{H}$

L104: $\mathrm{R}=\mathrm{NMe}_{2}$

Figure 25. Tridentate ligands L101-L104 conjugated with a stilbene A $\beta$-binding moiety designed for $\mathrm{A} \beta$ plaques binding, and the proposed structure of coordination compound 101.

The biodistribution of the radiolabeled coordination compound $\left[{ }^{99 m} \mathbf{T c}\right] 103$ was investigated in both wild-type and APP/PS1 Tg-mice. Low brain uptake $(\sim 0.25 \%)$ was registered in both cases, and no statistically significant difference between wild-type and $\mathrm{Tg}$-mice was observed.

Wang et al. reported four neutral Re/ ${ }^{99 \mathrm{~m}} \mathrm{Tc}-$ labeled coordination compounds $105-108 /\left[{ }^{99 \mathrm{~m}} \mathrm{Tc}\right]$ 105-108 based on arylbenzoxazole moieties conjugated with bis(aminoethanethiol) (BAT) as a chelating moiety [88] (Figure 26).

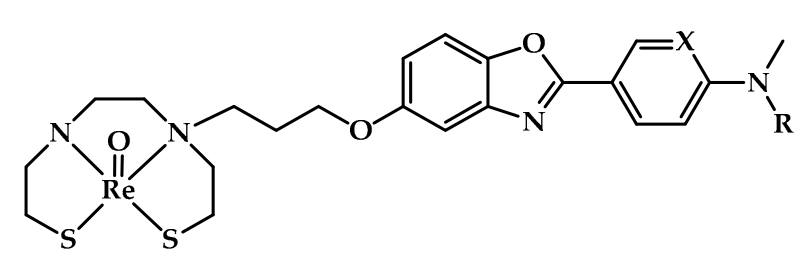

\author{
105: $\mathrm{R}=\mathrm{H}, \mathrm{X}=\mathrm{CH}$ \\ 106: $\mathrm{R}=\mathrm{H}, \mathrm{X}=\mathrm{N}$ \\ 107: $\mathrm{R}=\mathrm{CH}_{3}, \mathrm{X}=\mathrm{CH}$ \\ 108: $\mathrm{R}=\mathrm{CH}_{3}, \mathrm{X}=\mathrm{N}$
}

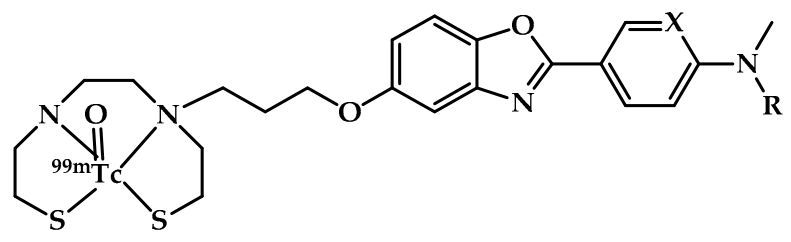

$\left[{ }^{99 m}\right.$ Tc]105: $\mathrm{R}=\mathrm{H}, \mathrm{X}=\mathrm{CH}$
$\left[{ }^{99 \mathrm{~m}}\right.$ Tc]106: $\mathrm{R}=\mathrm{H}, \mathrm{X}=\mathrm{N}$
$\left[{ }^{99 m}\right.$ Tc]107: $\mathrm{R}=\mathrm{CH}_{3}, \mathrm{X}=\mathrm{CH}$
$\left[{ }^{99 m}\right.$ Tc]108: $\mathrm{R}=\mathrm{CH}_{3}, \mathrm{X}=\mathrm{N}$

Figure 26. $\mathrm{Re}^{3+}(\mathbf{1 0 5}-\mathbf{1 0 8}){ }^{99 \mathrm{~m}} \mathrm{Tc}^{3+}\left(\left[{ }^{99 m} \mathrm{Tc}\right] \mathbf{1 0 5 - 1 0 8}\right)$ complexes based on arylbenzoxazole with a BAT metal-chelating moiety, designed for SPECT imaging of A $\beta$ plaques.

In vitro fluorescent staining with rhenium complexes 105-108 with $\mathrm{A} \beta$ plaques, neuropathological staining with the brain sections of a Tg-mice and an AD patient showed specific A $\beta$-binding of the complexes. An in vitro competition binding assay was performed using [ $\left.{ }^{125} \mathrm{I}\right] \mathrm{IMPY}$ as the competing radioligand. A moderate $A \beta$-binding affinity of 105 and $106\left(K_{i}=128.21\right.$ and $\left.393.18 \mathrm{nM}\right)$ and a high affinity of complexes 107 and $108\left(\mathrm{~K}_{\mathrm{i}}=15.86\right.$ and $\left.37.19 \mathrm{nM}\right)$ with $\mathrm{N}, \mathrm{N}$-dimethyl amino 
group was estimated. ${ }^{99 \mathrm{~m}} \mathrm{Tc}$-labeled complexes were prepared by a ligand exchange reaction from the intermediate ${ }^{99 \mathrm{~m}} \mathrm{Tc}$-glucoheptonate. In vitro autoradiography in Tg-mice brain tissue showed labeling of cortex, hippocampus, and cerebellum regions by [ $\left.{ }^{99 \mathrm{~m}} \mathrm{Tc}\right] 107$. Biodistribution studies of coordination compounds displayed higher initial brain uptake of $\mathrm{N}, \mathrm{N}$-dimethylated derivatives and brain $_{2 \mathrm{~min}} / \mathrm{brain}_{60 \mathrm{~min}}$ ratio than the N-monomethylated analogs $\left(\left[{ }^{99 \mathrm{~m}} \mathrm{Tc}\right] 105 \mathrm{vs}\left[{ }^{99 \mathrm{~m}} \mathrm{Tc}\right] 107\right.$ and $\left.\left[{ }^{99 \mathrm{~m}} \mathrm{Tc}\right] 106 \mathrm{vs}\left[{ }^{99 \mathrm{~m}} \mathrm{Tc}\right] 108\right)$.

Jia et al. reported a design and biological evaluation of a series of negatively charged imaging probes with limited BBB penetration for the selective detection of vascular $\mathrm{A} \beta$ deposition [89]. Eight ${ }^{99 \mathrm{~m}} \mathrm{Tc}(\mathrm{CO}){ }_{3}$-labeled benzothiazole derivatives [ $\left.{ }^{99 \mathrm{~m}} \mathrm{Tc}\right] 109-116$ and their $\mathrm{Re}(\mathrm{III})$ analogues 109-116 were designed as potential SPECT imaging probes for cerebrovascular A $\beta$ deposition (Figure 27). Rhenium surrogates 109-116 displayed high affinities to $A \beta$ aggregates with $K_{i}$ values ranging from 42 to $106 \mathrm{nM}$, rhenium complex 116 with the longest carbon linker length $(n=6)$ displayed the highest affinity to $A \beta_{1-42}$ aggregates $\left(K_{i}=42.2 \mathrm{nM}\right)$. Complex 115 also demonstrated unambiguous and specific labeling of $\mathrm{A} \beta$ plaques in brain sections from $\mathrm{Tg}$-mice. ${ }^{99 \mathrm{~m}} \mathrm{Tc}-$ labeled coordination compounds $\left[{ }^{99 \mathrm{~m}} \mathrm{Tc}\right] 109-116$ were obtained by ligand exchange reactions with fac- $\left[{ }^{99 \mathrm{~m}} \mathrm{Tc}(\mathrm{CO})_{3}\left(\mathrm{H}_{2} \mathrm{O}\right)_{3}\right]^{+}$.

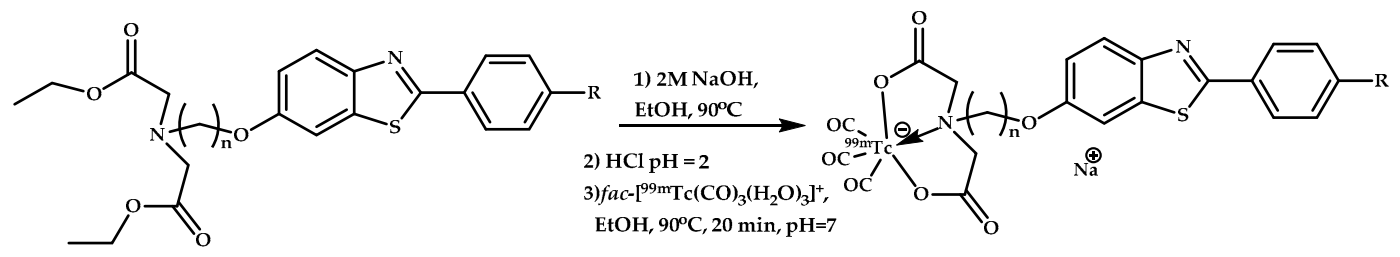

L109: $\mathrm{n}=3$, R=NHMe; 113: $\mathrm{n}=3, \mathrm{R}=\mathrm{N}(\mathrm{Me})_{2}$ L110: $\mathrm{n}=4, \mathrm{R}=\mathrm{NHMe}$; 114: $\mathrm{n}=4, \mathrm{R}=\mathrm{N}(\mathrm{Me})_{2}$ L111: $\mathrm{n}=5, \mathrm{R}=\mathrm{NHMe} ; 115: \mathrm{n}=5, \mathrm{R}=\mathrm{N}(\mathrm{Me})_{2}$ L112: $n=6, R=N H M e ; 116: n=6, R=N(M e)_{2}$

\begin{abstract}
[99m Tc]109: $\mathrm{n}=3, \mathrm{R}=\mathrm{NHMe} ; 113: \mathrm{n}=3, \mathrm{R}=\mathrm{N}(\mathrm{Me})_{2}$ [99m Tc]110: $\mathrm{n}=4, \mathrm{R}=\mathrm{NHMe} ; 114: \mathrm{n}=4, \mathrm{R}=\mathrm{N}(\mathrm{Me})_{2}$ [99m Tc]111: $n=5, R=$ NHMe; 115: $n=5, R=N M e)_{2}$ [99m Tc]112: $\mathrm{n}=6, \mathrm{R}=\mathrm{NHMe} ; 116: \mathrm{n}=6, \mathrm{R}=\mathrm{N}(\mathrm{Me})_{2}$
\end{abstract}

Figure 27. Negatively charged imaging probes [ $\left.{ }^{99 \mathrm{~m}} \mathrm{Tc}\right] \mathbf{1 0 9 - 1 1 6}$ designed for the selective detection of vascular $\mathrm{A} \beta$ deposition, and their $\mathrm{Re}^{3+}$ analogues 109-116.

Autoradiography studies in AD human brain tissue proved the ability of coordination compound $\left[{ }^{99 m} \mathrm{Tc}\right] 116$ to bind $A \beta$ deposits in blood vessels but not in cerebral parenchyma on brain sections of an AD patient, while [ $\left.{ }^{125} \mathrm{I}\right] \mathrm{IMP}$ labeled both. Ex vivo autoradiography studies in Tg-mice and wild-type mice were also performed. The radioactive spots were found to concentrate at the site of the blood vessels in the Tg-mice brain tissue, as identified by in vitro fluorescence staining using thioflavin-S. Biodistribution studies of $\left[{ }^{99 \mathrm{~m}} \mathrm{Tc}\right] 116$ show a relatively low brain uptake equal to $1.21 \% \pm 0.22 \% \mathrm{ID} / \mathrm{g}$ at $2 \mathrm{~min}$ post-injection and rapid blood washout with an approximately 23 -fold decline in blood radioactivity at $60 \mathrm{~min}$ post-injection. Other complexes showed worse brain uptake. The authors claimed that coordination compounds [ $\left.{ }^{99 \mathrm{~m}} \mathrm{Tc}\right] 109-116$ are prospective as cerebrovascular A $\beta$-visualization agents.

Zhang et al. designed a series of sixteen ${ }^{99} \mathrm{~m}$ Tc-labeled imaging probes [ $\left.{ }^{99 m} \mathrm{Tc}\right] \mathbf{1 1 7 - 1 3 2}$ for $\mathrm{A} \beta$ plaques based on 2-arylbenzothiazoles conjugated with a bis(aminoethanethiol) (BAT) chelating moiety and their Re(III) analogues 117-132 [90] (Figure 28). An in vitro binding affinity of rhenium complexes 117-132 to aggregated $\mathrm{A} \beta_{1-42}$ peptide was estimated by a competitive binding assay using [ ${ }^{125} \mathrm{I}$ ]IMPY as a reference ligand. The results obtained proved that both the introduction of a dimethylamine group and an increase in the length of the linker between the amyloid affinity and the metal-chelating moiety promotes $\mathrm{A} \beta$ binding of the resulting coordination compounds. Compounds $\mathbf{1 2 0}$ and $\mathbf{1 2 2}$ showed a binding affinity (respectively 8.4 and $8.8 \mathrm{nM}$ ) surpassing that of IMPY, a widely used imaging agent. Binding of the coordination compound to $\mathrm{A} \beta$ plaques in Tg-mice and $\mathrm{AD}$ brain tissue samples was also proven using in vitro fluorescent staining with thioflavin-S as a control. 
${ }^{99} \mathrm{~m}$ Tc-labeled probes [ $\left.{ }^{99 m} \mathrm{Tc}\right] \mathbf{1 1 7}-\mathbf{1 3 2}$ were obtained using a ligand exchange reaction with ${ }^{99 \mathrm{~m}} \mathrm{Tc}-$ glucoheptonate. The ability of the purified ${ }^{99 \mathrm{~m}} \mathrm{Tc}$-labeled probes [ $\left.{ }^{99 \mathrm{~m}} \mathrm{Tc}\right] \mathbf{1 1 8}-\mathbf{1 3 4}$ to bind $\mathrm{A} \beta$ plaques was tested in brain slices from Tg-mice. Biodistribution studies of ${ }^{99 \mathrm{~m}} \mathrm{Tc}-l$ abeled complexes were conducted. [ $\left.{ }^{99 \mathrm{~m}} \mathrm{Tc}\right] \mathbf{1 2 4}$ indicated its suitability as a diagnostic probe. ${ }^{99 \mathrm{~m}} \mathrm{Tc}$-labeled coordination compound [ $\left.{ }^{99 \mathrm{~m}} \mathrm{Tc}\right] \mathbf{1 2 4}$ showed relatively high initial brain uptake $(2.11 \% \mathrm{ID} / \mathrm{g}$ at $2 \mathrm{~min})$ and a reasonable clearance rate $(0.62 \% \mathrm{ID} / \mathrm{g}$ at $60 \mathrm{~min})$, in contrast to other complexes, which exhibited poor brain uptake (less than $1 \% \mathrm{ID} / \mathrm{g}$ at $2 \mathrm{~min}$ ) and slow clearance, presumably because of their higher lipophilicity and nonspecific binding to plasma proteins.

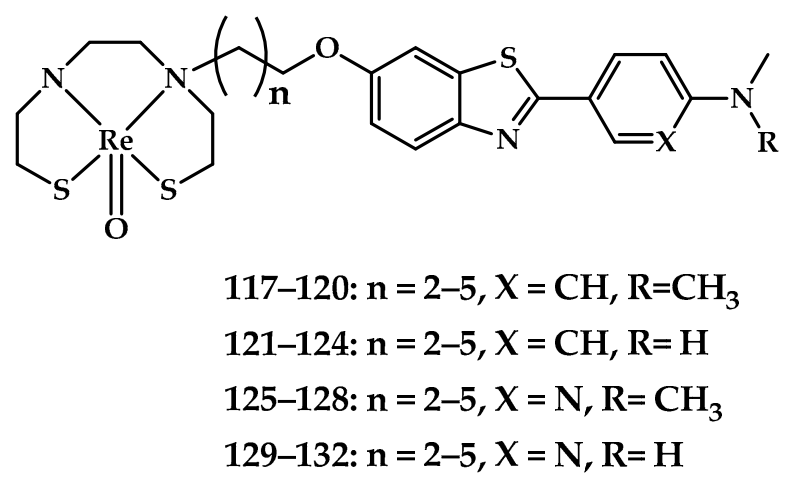

Figure 28. Re(III) coordination compounds 117-132 based on 2-arylbenzothiazoles conjugated with a BAT chelating moiety.

SPECT images of coordination compound $\left[{ }^{99 \mathrm{~m}} \mathrm{Tc}\right] 122$ in rhesus monkeys were registered, and the images revealed radioactivity accumulation in the brain, indicating permeation of $\left[{ }^{99 \mathrm{~m}} \mathrm{Tc}\right] \mathbf{1 2 1}$ through the BBB (Table 6). This is the first assessment of a ${ }^{99} \mathrm{~m}$ Tc-labeled $\mathrm{A} \beta$ probe in nonhuman primates.

Table 6. [ $\left.{ }^{99 m} \mathrm{Tc}\right] \mathbf{1 2 2}$ brain accumulation in rhesus monkeys (M04: 4-year-old, male; F27: 27-year-old, female).

\begin{tabular}{cccccc}
\hline & 0-10 Min & 10-20 Min & 20-30 Min & 30-40 Min & Clearance Ratio \\
\hline M04 & 1.23 & 1.13 & 1.01 & 0.88 & 1.40 \\
F27 & 0.78 & 0.70 & 0.67 & 0.64 & 1.22 \\
\hline
\end{tabular}

Hayne et al. reported oxotechentium(V) and oxorhenium(V) complexes [ $\left.{ }^{99 m} \mathrm{Tc}\right] \mathbf{1 3 3}$ and $\mathbf{1 3 3}$ based on a styrylpyridyl functional group with 2-aminoethyl-2-hydroxybenzamide as a chelating moiety [91] (Figure 29). The affinity of $\mathbf{1 3 3}$ for $\mathrm{A} \beta_{1-42}$ fibrils was estimated to be $K_{i}=855 \mathrm{nM}$ using a fluorescence competition assay against Thioflavin T. It was also shown that $\mathbf{1 3 3}$ binds to $\mathrm{A} \beta$ plaques in human brain tissue using human AD brain sections.

Kiritsis et al. reported a 2-(4'-aminophenyl)benzothiazole-based ${ }^{99 \mathrm{~m}} \mathrm{Tc}$-radioagent $\left[{ }^{99 \mathrm{~m}} \mathrm{Tc}\right] 134$ and its Re(III) analogue 134 [92] (Figure 30). A strong affinity of $\mathbf{1 3 4}$ for $\mathrm{A} \beta$ plaques in brain sections from an AD patient was proven using confocal microscopy. The binding affinity of $\mathbf{1 3 4}$ for $A \beta_{42}$ was measured in vitro by competition binding assay between the stable 134 and its radioactive ${ }^{99 \mathrm{~m}}$ Tc-labeled analogue $\left[{ }^{99 \mathrm{~m}} \mathrm{Tc}\right] 134$, and the obtained $\mathrm{K}_{\mathrm{i}}$ was $13.6 \pm 4.8 \mathrm{nM}$.

Biodistribution experiments of $\left[{ }^{99 m} \mathrm{Tc}\right] 134$ in Swiss albino mice revealed a moderate initial brain uptake of $0.53 \% \mathrm{ID} / \mathrm{g}$ at $2 \mathrm{~min}$ and slow clearance of radioactivity from the brain with a brain $_{2 \mathrm{~min}} /$ brain $90 \mathrm{~min}$ ratio of 2.1. Administration of [ $\left.{ }^{99 \mathrm{~m}} \mathrm{Tc}\right] 134$ in $5 \times \mathrm{xAD}$ Tg-mice showed that $0.52 \%$ $\mathrm{ID} / \mathrm{g}$ of radioactivity is recorded in the brain at $2 \mathrm{~min}$, a result similar to that in healthy mice. But the significant increase of radioactivity in the brain of 5xFAD Tg-mice with time $(1.94 \% \mathrm{ID} / \mathrm{g}$ at $90 \mathrm{~min}$ post-injection) is consistent with retention of $\left[{ }^{99 \mathrm{~m}} \mathrm{Tc}\right] 134$ through binding to $\mathrm{A} \beta$ plaques.

Iikuni et al. reported three novel ${ }^{99 \mathrm{~m}} \mathrm{Tc}$ complexes $\left[{ }^{99 \mathrm{~m}} \mathrm{Tc}\right] 135-137$ based on a phenylquinoxaline scaffold and their model Re(III) analogues 135-137 [93] (Figure 31). 


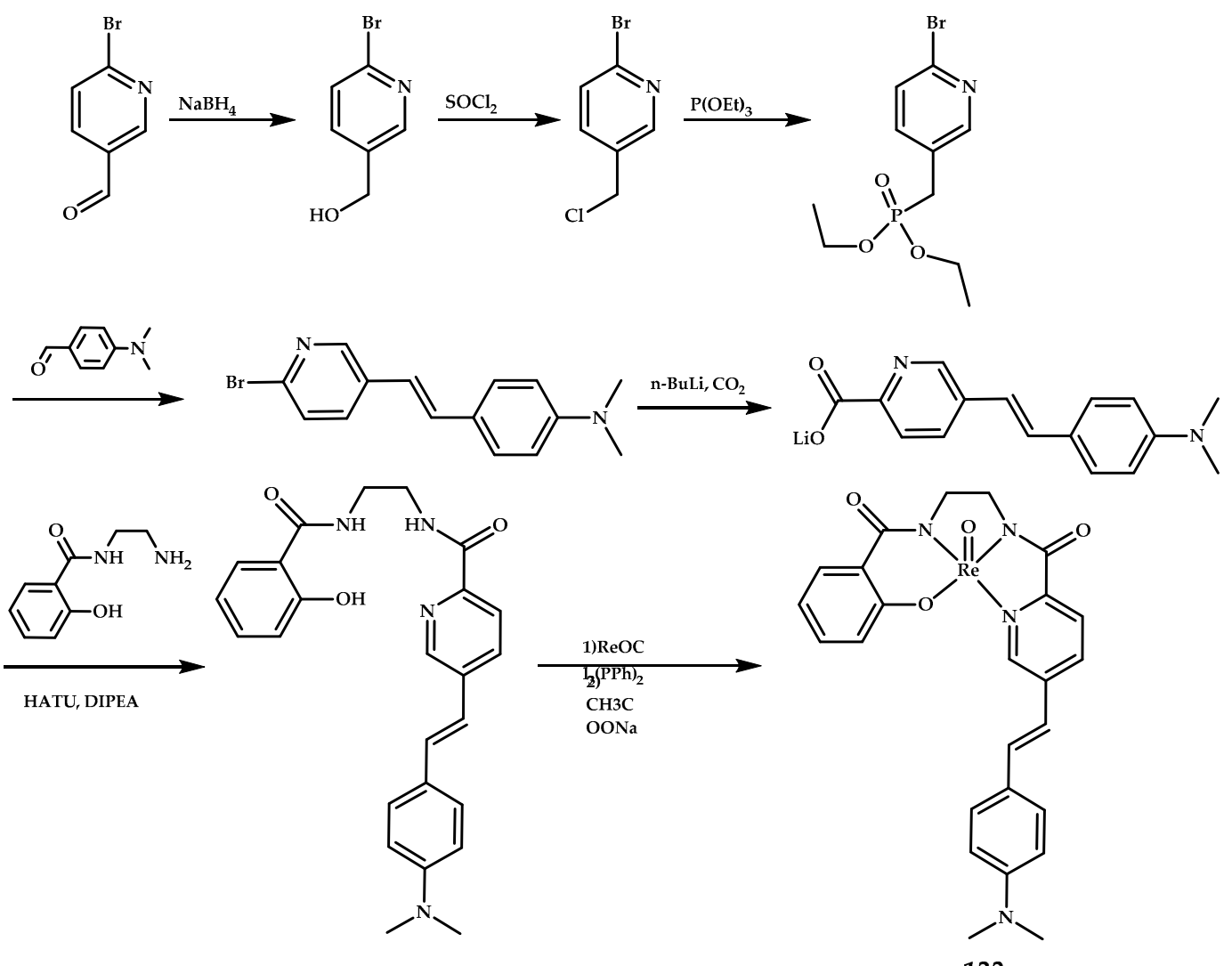

Figure 29. Oxorhenium(V) complexes 133 based on a styrylpyridyl functional group with 2-aminoethyl-2-hydroxybenzamide as a chelating moiety, designed for SPECT imaging of A $\beta$ plaques.
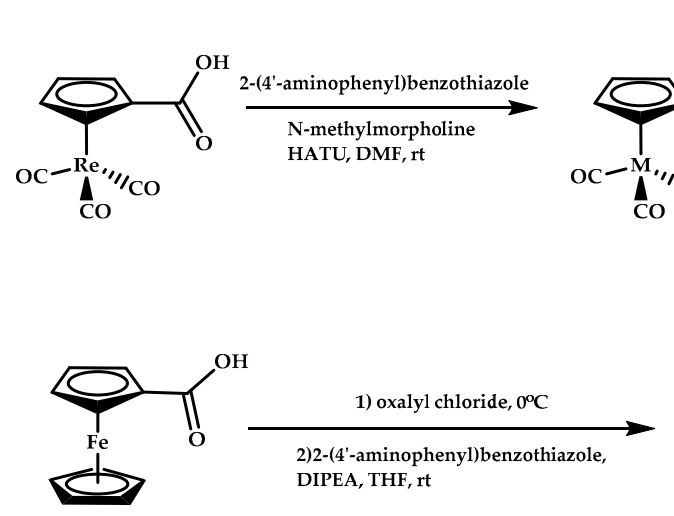

134: $M=\operatorname{Re}$ [ ${ }^{99 m}$ Tc]134: $M={ }^{99} \mathrm{~m} T c$

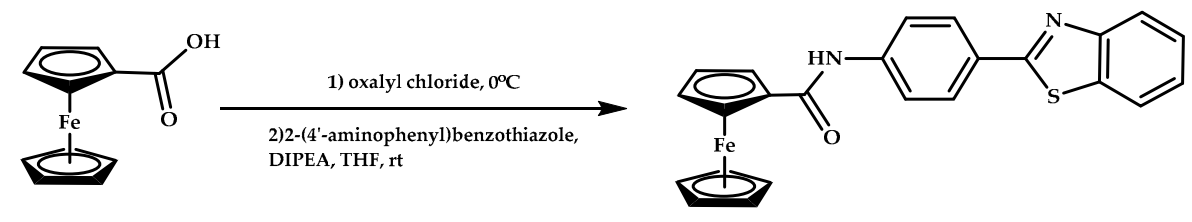

Figure 30. 2-(4'-aminophenyl)benzothiazole-based ${ }^{99 \mathrm{~m}}$ Tc-radioagent $\left[{ }^{99 \mathrm{~m}} \mathrm{Tc}\right] 134$ and its $\operatorname{Re}(\mathrm{III})$ analogue 134, designed for SPECT imaging of $\mathrm{A} \beta$ plaques.

An in vitro binding experiment in solution showed promising $A \beta$ affinity for complex $\mathbf{1 3 5}$ and average binding affinity for complex $\mathbf{1 3 6}$. The affinity increased in the order of the $\mathrm{N}, \mathrm{N}$-dimethylated derivative $>\mathrm{N}$-monomethylated derivative $>$ primary amino derivative.

The brain uptake for ${ }^{99 \mathrm{~m}} \mathrm{Tc}-$ labeled complex [ $\left.{ }^{99 \mathrm{~m}} \mathrm{Tc}\right] 135$ was found to be $0.88 \%$, and the brain $_{2 \mathrm{~min}} /$ brain $_{60 \mathrm{~min}}$ ratio was 3.52 . An ex vivo autoradiographic examination was also performed using a Tg2576 mice, and $\left.{ }^{99 \mathrm{~m}} \mathrm{Tc}\right] \mathbf{1 3 5}$ showed intensive radioactive spots in sections from the $\mathrm{Tg} 2576$ mice but not from the age-matched mice. In addition, these spots corresponded with $A \beta$ depositions confirmed by fluorescent staining in the same sections with thioflavin-S. 


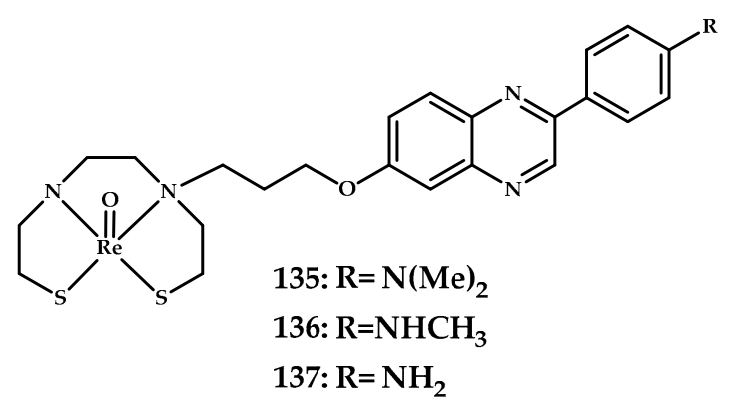

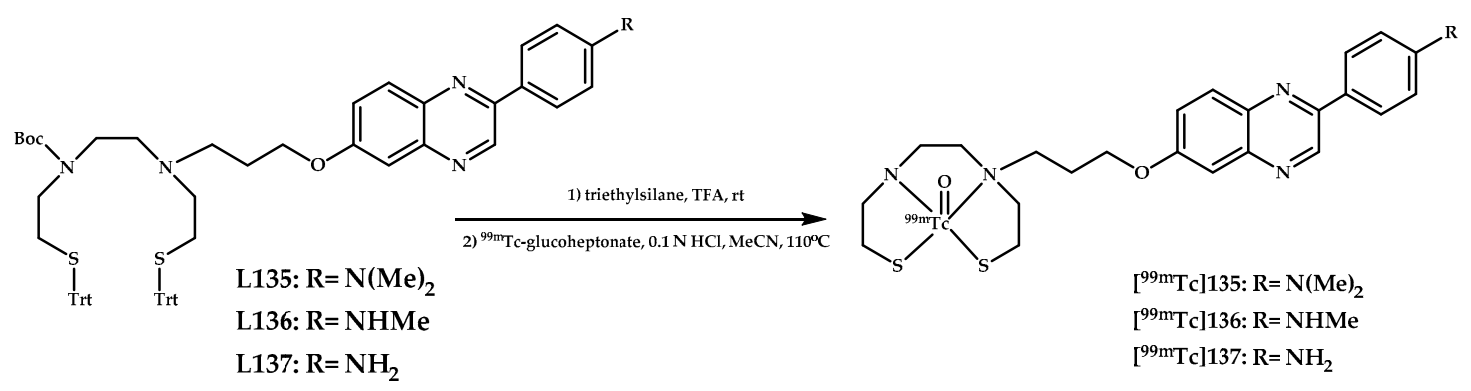

Figure 31. ${ }^{99 \mathrm{~m}} \mathrm{Tc}$ complexes [ $\left.{ }^{99 \mathrm{~m}} \mathrm{Tc}\right] \mathbf{1 3 5}-\mathbf{1 3 7}$ based on a phenylquinoxaline scaffold and their model $\operatorname{Re}(I I I)$ analogues $\mathbf{1 3 5 - 1 3 7}$, designed for SPECT imaging of A $\beta$ plaques.

Fletcher et al. reported six $\operatorname{Re}(\mathrm{III})$ complexes 138-142 based on styrilpyridyl and benzofuran moieties [94] (Figure 32). An affinity to $A \beta$ plagues was investigated using a ThT assay, and the obtained results suggested that the complexes either bind competitively with ThT to $A \beta_{1-42}$ fibrils or inhibit fibril formation. ${ }^{99 \mathrm{~m}} \mathrm{Tc}-$ labeled coordination compounds $\left[{ }^{99 \mathrm{~m}} \mathrm{Tc}\right] 138$ and $\left[{ }^{99 \mathrm{~m}} \mathrm{Tc}\right] 139$ were also obtained.
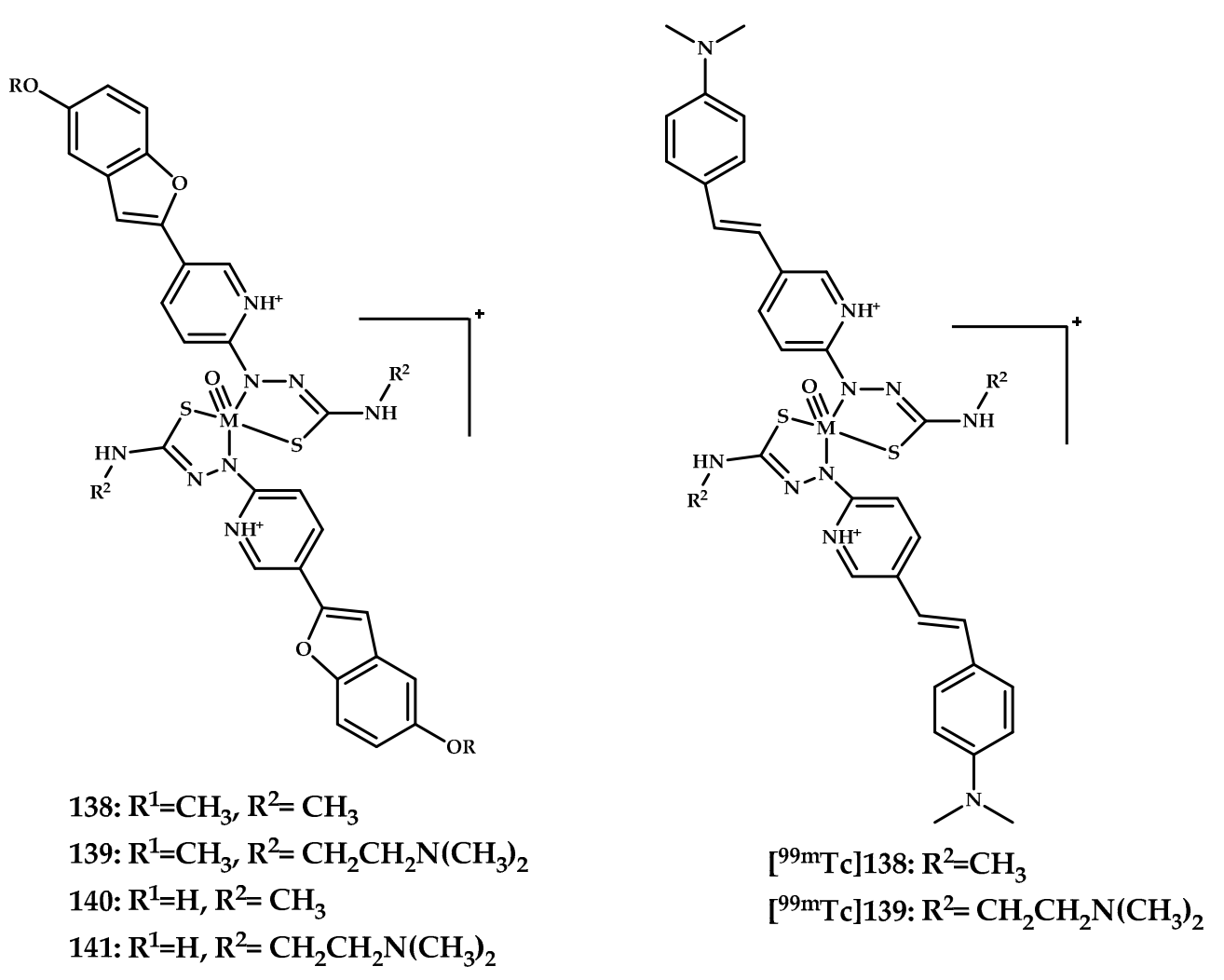

Figure 32. Re(III) complexes 138-142 based on styrilpyridyl and benzofuran moieties, and ${ }^{99} \mathrm{~m}$ Tc labeled coordination compounds [ $\left.{ }^{99 \mathrm{~m}} \mathrm{Tc}\right] \mathbf{1 3 8}$ and $\left[{ }^{99 \mathrm{~m}} \mathrm{Tc}\right] \mathbf{1 3 9}$, designed for SPECT imaging of A $\beta$ plaques. 
Molavipordanjani et al. reported two novel radiolabeled 2-arylimidazo[2,1-b]benzothiazoles 143 and 144 [95] (Figure 33). The affinity of the coordination compounds for $A \beta_{1-42}$ aggregates was evaluated, and both radiolabeled complexes showed a significant $A \beta$ binding. Tissue staining and autoradiography with Congo Red as a control proved an ability of the obtained complexes 143 and 144 to bind to $\mathrm{A} \beta$ plaques in the brain sections of the rat $\mathrm{AD}$ model. Biodistribution studies in normal BALB/C mice showed an initial brain uptake of $0.78 \%$ and $0.86 \%$ ID/g respectively, for 143 and 144 in normal mice, followed by a nearly complete washout within an hour.

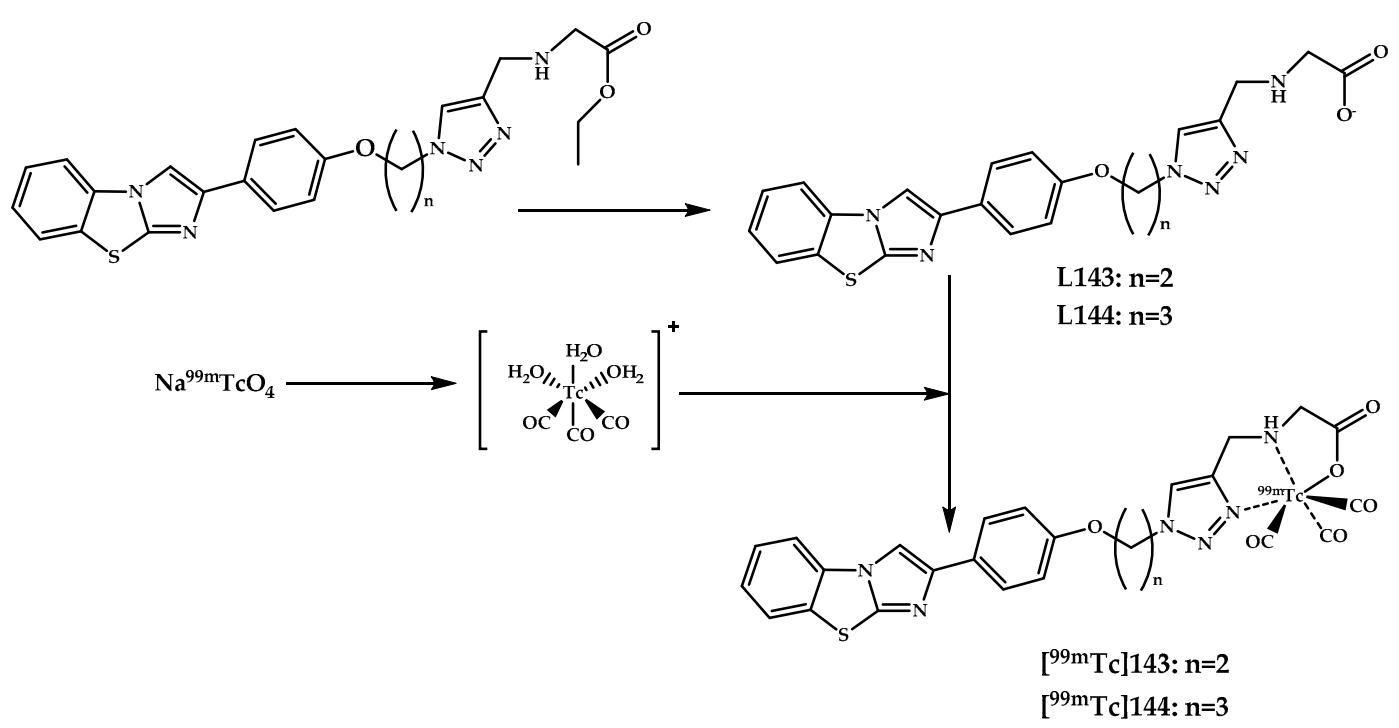

Figure 33. Radiolabeled 2-arylimidazo[2,1-b]benzothiazoles 143 and 144, designed for SPECT imaging of $\mathrm{A} \beta$ plaques.

Sagnou et al. reported synthesis of three novel ${ }^{99 \mathrm{~m}} \mathrm{Tc}$ complexes $\left[{ }^{99 \mathrm{~m}} \mathrm{Tc}\right] \mathbf{1 4 5}-\left[{ }^{99 \mathrm{~m}} \mathrm{Tc}\right] \mathbf{1 4 7}$ and their corresponding Re analogues 145-147, in which the phenyl ring of the classical A $\beta$-binding structures 2-phenylbenzothiazole or 2-phenylbenzimidazole is replaced by cyclopentadienyl tricarbonyl $\left[\mathrm{Cp}^{99 \mathrm{~m}} \mathrm{Tc}(\mathrm{CO})_{3}\right][96]$ (Figure 34).

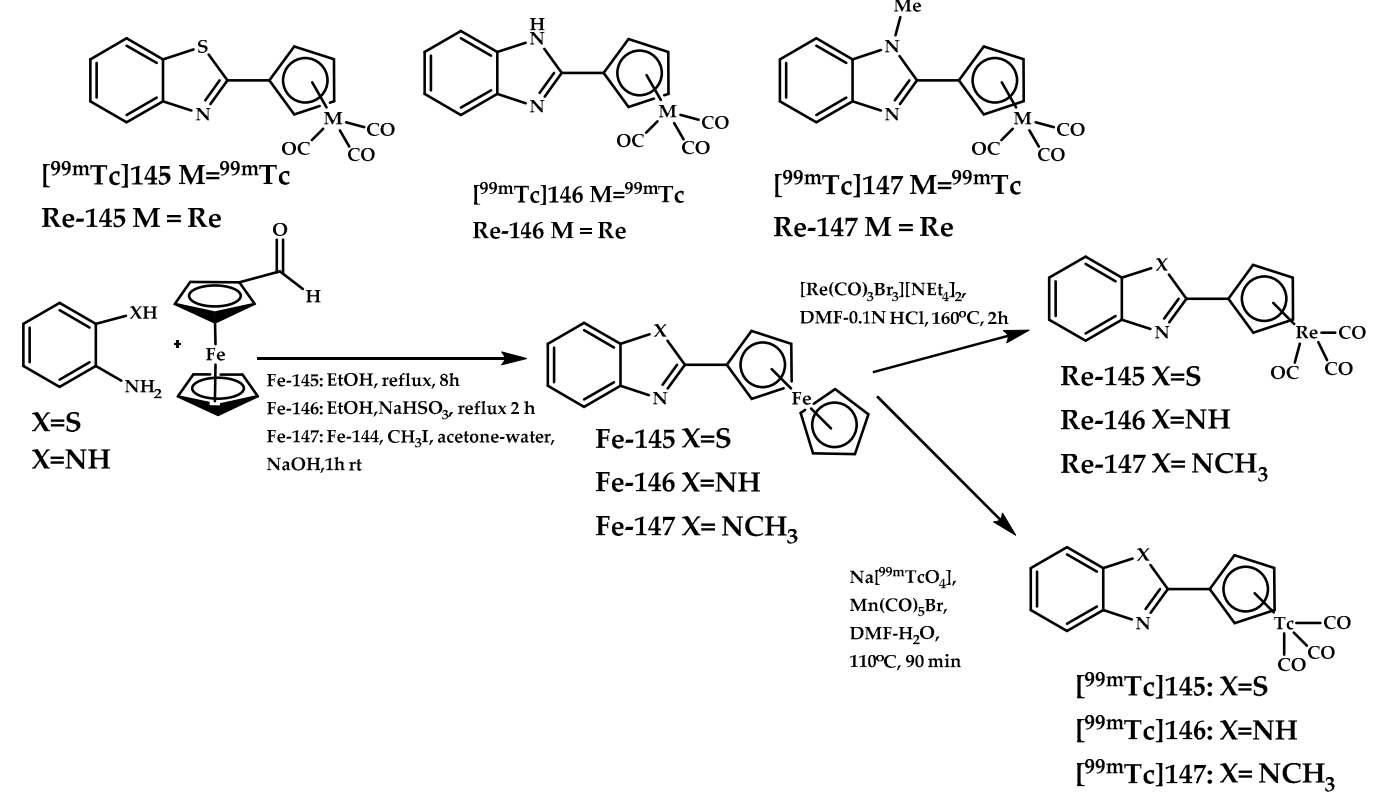

Figure 34. ${ }^{99 \mathrm{~m}} \mathrm{Tc}$ complexes $\left[{ }^{99 \mathrm{~m}} \mathrm{Tc}\right] 145-\left[{ }^{99 \mathrm{~m}} \mathrm{Tc}\right] 147$ and their corresponding Re analogues $145-147$ designed for SPECT imaging of $A \beta$ plaques. 
The affinity of complexes 145-147 for A $\beta$ plaques was evaluated with confocal microscopy on human AD brain sections. All three complexes bind selectively to the $\mathrm{A} \beta$ plaques. Competition binding assays between the stable Re complexes $\mathbf{1 4 5 - 1 4 7}$ and their radioactive ${ }^{99 \mathrm{~m}} \mathrm{Tc}$ counterparts $\left[{ }^{99 m} \mathrm{Tc}\right] 145-\left[{ }^{99 m} \mathrm{Tc}\right] 147$ showed $K_{i}$ values of $65.8 \pm 21.3,7.0 \pm 2.9$, and $5.7 \pm 2.9 \mathrm{nM}$. Biodistribution experiments showed brain uptake of $\left[{ }^{99 m} \mathrm{Tc}\right] 145(7.94 \pm 1.46 \%)$ comparable to that of ${ }^{18} \mathrm{~F}$-florbetapir ( $7.33 \% \mathrm{ID} / \mathrm{g}$ at $2 \mathrm{~min})$, fast blood clearance, and lack of retention in brain tissue.

Biodistribution of [ $\left.{ }^{99 m} \mathrm{Tc}\right] \mathbf{1 4 5}$ in 5xFAD Tg-mice showed AD brain accumulation of $3.90 \pm 0.19$ for Tg-mice and $2.68 \pm 0.06$ for wild-type mice (15 min post-injection). The Re complexes 145-147 also showed an anti-amyloid therapeutic potential.

Jokar et al. designed a ${ }^{99} \mathrm{~m} \mathrm{Tc}$ agent 148 with a lipophilic peptide scaffold, ${ }^{99 \mathrm{~m}}$ Tc-Cp-GABA-D-(FPLIAIMA)-NH 2 [97] (Figure 35).

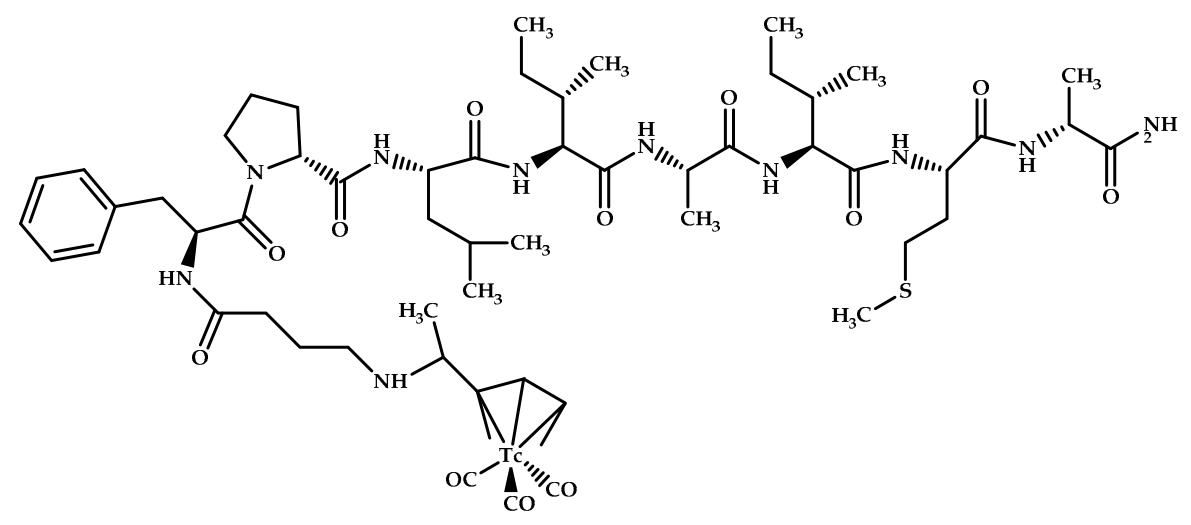

146

Figure 35. ${ }^{99 \mathrm{~m}} \mathrm{Tc}-\mathrm{Cp}$-GABA-D-(FPLIAIMA)- $\mathrm{NH}_{2} 148$ based on an A $\beta$-affinitive peptide scaffold, designed for SPECT imaging of $A \beta$ plaques.

Binding affinity studies were carried out on $A \beta$ aggregation, and the respective observed values of $K_{d}$ and $B_{\max }$ were $20.22 \pm 7.26 \mu \mathrm{M}$ and 201,700 \pm 8750.89 bound molecules/plaque. In vitro autoradiography studies, scintigraphy, and fluorescence staining were performed on the brain sections of $\mathrm{AD}$ and normal rats and also on brain sections of $\mathrm{AD}$, normal, and schizophrenia patients for better confirmation. The radiopeptide displayed a good binding affinity for the $\mathrm{A} \beta$ plaques on brain sections of $\mathrm{AD}$ rats and a significant binding affinity for $\mathrm{A} \beta$ plaques in human brain sections. Brain uptake in $\mathrm{AD}$ and normal rats was respectively $0.38 \%$ and $0.35 \%$, and brain uptake of radiopeptide on $\mathrm{AD}$ brain increased 2 min post-injection and slowly dropped at $30 \mathrm{~min}$, as compared with normal ones. Biodistribution studies in the presence of a p-glycoprotein (PgP) blocker and SPECT/CT imaging studies were also performed following intravenous administration of the probe. The analyzed images showed significant radioactivity uptake in the AD brains compared with uptake in normal rats.

\section{Conclusions}

Among various strategies utilized to obtain copper-based AD imaging agents, compound 1 with a low molecular mass and ATSM chelating moiety demonstrated the highest level of brain uptake at $2 \mathrm{~min}$ post-injection. We note that modification of the ATSM moiety with polyamine led to a significant increase in brain uptake. Other Cu-chelating fragments such as DOTA lead to a decrease in brain uptake compared with Cu-ATSM-based complexes.

$\mathrm{Gd} / \mathrm{Ga}$ complexes designed for MRI and PET imaging of $\mathrm{A} \beta$ showed good in vitro activity, but when tested in vivo, those compounds showed little to no BBB penetration, which can result from the presence of rigid DOTA/DO3A, etc., scaffolds used to chelate $\mathrm{Gd} / \mathrm{Ga}$. The most potent compound 
71 demonstrated a brain uptake of $1.24 \% \mathrm{ID} / \mathrm{g}$ at 2 min post-injection despite a MW $\approx 1000$, which is far beyond the optimal mass for BBB penetration.

Some of the ${ }^{99 \mathrm{~m}} \mathrm{Tc}-\mathrm{based}$ coordination compounds demonstrated promising in vitro and in vivo activity. The most potent complexes for SPECT imaging were compounds 145-147 with piano stool moieties coupled with $A \beta$-binding benzothiazole scaffolds, with 145 showing a brain uptake of $7.94 \%$ at 2 min post-injection. When rigid chelating structures, long linkers, and heavy $A \beta$-binding fragments are used, the BBB penetrability of the resulting coordination compounds decreases dramatically, as shown for 92-95 and 107-132.

Metal-based imaging agents for $\mathrm{AD}$ allow noninvasive imaging of $\mathrm{A} \beta$ plaques, a crucial procedure for successful AD diagnosis and therapy. There is a strong need for new efficient AD imaging probes, and this area of research is therefore thriving. The radioisotopes ${ }^{64} \mathrm{Cu},{ }^{68} \mathrm{Ga}$, and ${ }^{99 \mathrm{~m}} \mathrm{Tc}$ are promising and can be obtained either by cyclotrons or by radioisotope generators. They also have half-lives much longer than do ${ }^{18} \mathrm{~F}$ and ${ }^{11} \mathrm{C}$, which are currently used for imaging. Radioactive metal isotopes can be introduced at the last step of synthesizing an imaging agent, which reduces the potential activity loss.

Among the vast variety of compounds considered in this review, the most promising results were shown by $\mathrm{Cu}^{2+}$-based coordination compounds $\mathbf{1}$ and $\mathbf{1 1}$ for PET imaging, $\mathrm{Gd}^{3+}$-based coordination compound 40 for MRI, and ${ }^{99} \mathrm{~m}$ Tc-based coordination compound 145 for SPECT imaging, demonstrating the best $\mathrm{A} \beta$-binding affinity and brain uptake at $2 \mathrm{~min}$ post-injection while being light-weight complexes with small $\mathrm{A} \beta$-binding fragments.

Author Contributions: Conceptualization, O.K. and D.S.; Writing-Original Draft Preparation, O.K. and D.S.; Writing-Review \& Editing, O.K., D.S., A.Z., K.P., P.G., A.E.; Visualization, D.S., A.Z., K.P.; Supervision, P.G., A.E.; Project Administration, E.B. A.M.; Funding Acquisition, P.G., A.E., A.M. All authors have read and agreed to the published version of the manuscript.

Funding: This research was funded by the Ministry of Education and Science of the Russian Federation implemented by governmental decree No. 211 dated 16 March 2013, and by the Russian Science Foundation, Grant No. 20-14-00312.

Conflicts of Interest: The authors declare no conflict of interest.

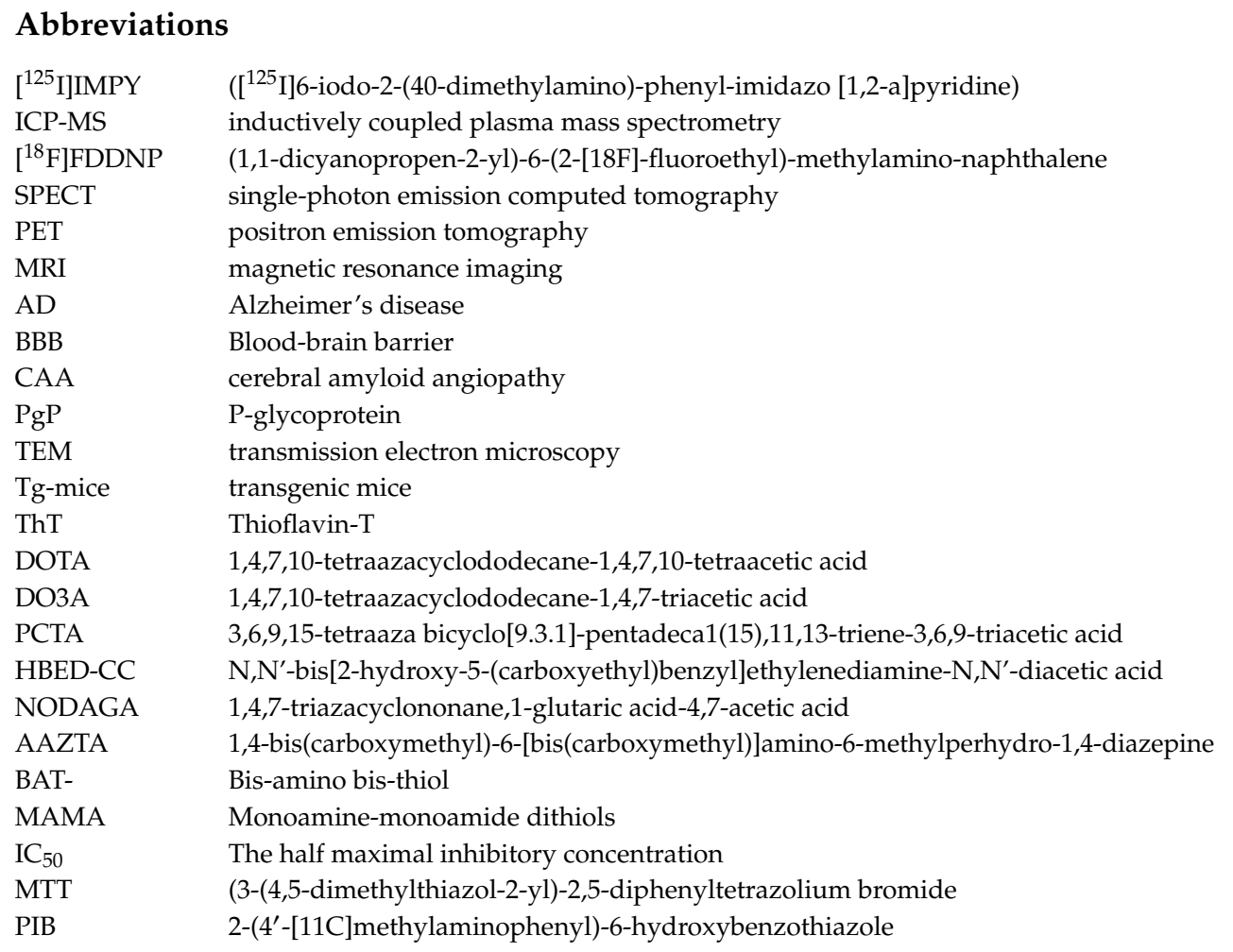




\section{References}

1. Penke, B.; Szúcs, M.; Bogár, F. Oligomerization and Conformational Change Turn Monomeric $\beta$-Amyloid and Tau Proteins Toxic: Their Role in Alzheimer's Pathogenesis. Molecules 2020, 25, 1659. [CrossRef]

2. Chen, G.-F.; Xu, T.-H.; Yan, Y.; Zhou, Y.-R.; Jiang, Y.; Melcher, K.; Xu, H.E. Amyloid beta: Structure, biology and structure-based therapeutic development. Acta Pharmacol. Sin. 2017, 38, 1205-1235. [CrossRef]

3. Savelieff, M.G.; Lee, S.; Liu, Y.; Lim, M.H. Untangling Amyloid- $\beta$, Tau, and Metals in Alzheimer's Disease. ACS Chem. Biol. 2013, 8, 856-865. [CrossRef]

4. LaFerla, F.M.; Green, K.N.; Oddo, S. Intracellular amyloid- $\beta$ in Alzheimer's disease. Nat. Rev. Neurosci. 2007, 8, 499-509. [CrossRef]

5. Verhoeff, N.P.; Wilson, A.A.; Takeshita, S.; Trop, L.; Hussey, D.; Singh, K.; Kung, H.F.; Kung, M.P.; Houle, S. In-vivo imaging of Alzheimer disease beta-amyloid with [11C]SB-13 PET. Am. J. Geriatr. Psychiatry 2004, 12, 584-595.

6. Rowe, C.C.; Villemagne, V.L. Brain Amyloid Imaging. J. Nucl. Med. Technol. 2013, 41, 11-18. [CrossRef]

7. Roe, C.M.; Fagan, A.M.; Grant, E.A.; Hassenstab, J.; Moulder, K.L.; Dreyfus, D.M.; Sutphen, C.L.; Benzinger, T.L.S.; Mintun, M.A.; Holtzman, D.M.; et al. Amyloid imaging and CSF biomarkers in predicting cognitive impairment up to 7.5 years later. Neurology 2013, 80, 1784-1791. [CrossRef]

8. Therriault, J.; Benedet, A.; Pascoal, T.A.; Savard, M.; Ashton, N.; Chamoun, M.; Tissot, C.; Lussier, F.; Kang, M.S.P.; Bezgin, G.; et al. Determining Amyloid- $\beta$ positivity using $\left[{ }^{18} \mathrm{~F}\right] \mathrm{AZD}_{4694}$ PET imaging. J. Nucl. Med. 2020, 120, 245209.

9. Chang, Y.; Li, C.; Yang, H.; Wu, Y.; Xu, B.; Zhang, J.; Wang, R. ${ }^{18}$ F-Florbetaben Amyloid PET Imaging: A Chinese Study in Cognitive Normal Controls, Mild Cognitive Impairment, and Alzheimer's Disease Patients. Front. Neurosci. 2020, 14, 745. [CrossRef]

10. Cohen, A.D.; Rabinovici, G.D.; Mathis, C.A.; Jagust, W.J.; Klunk, W.E.; Ikonomovic, M.D. Using Pittsburgh Compound B for In Vivo PET Imaging of Fibrillar Amyloid-Beta. Adv. Pharmacol. 2012, 64, $27-81$.

11. Carotenuto, A.; Giordano, B.; Dervenoulas, G.; Wilson, H.; Veronese, M.; Chappell, Z.; Polychronis, S.; Pagano, G.; Mackewn, J.; Turkheimer, F.E.; et al. $\left[{ }^{18} \mathrm{~F}\right]$ Florbetapir PET/MR imaging to assess demyelination in multiple sclerosis. Eur. J. Nucl. Med. Mol. Imaging 2020, 47, 366-378. [CrossRef] [PubMed]

12. Chételat, G.; Arbizu, J.; Barthel, H.; Garibotto, V.; Law, I.; Morbelli, S.; van de Giessen, E.; Agosta, F.; Barkhof, F.; Brooks, D.J.; et al. Amyloid-PET and 18F-FDG-PET in the diagnostic investigation of Alzheimer's disease and other dementias. Lancet Neurol. 2020, 19, 951-962. [CrossRef]

13. Moynier, F.; Creech, J.; Dallas, J.; Le Borgne, M. Serum and brain natural copper stable isotopes in a mice model of Alzheimer's disease. Sci. Rep. 2019, 9, 1-7. [CrossRef]

14. Lau, J.; Rousseau, E.; Kwon, D.; Lin, K.-S.; Bénard, F.; Chen, X. Insight into the Development of PET Radiopharmaceuticals for Oncology. Cancers 2020, 12, 1312. [CrossRef] [PubMed]

15. Meisenheimer, M.; Saenko, Y.; Eppard, E. Gallium-68: Radiolabeling of Radiopharmaceuticals for PET Imaging-A Lot to Consider. Med Isot. 2019. [CrossRef]

16. Romero, E.; Martínez, A.; Oteo, M.; Ibañez, M.; Santos, M.; Morcillo, M.Á. Development and long-term evaluation of a new ${ }^{68} \mathrm{Ge} /{ }^{68} \mathrm{Ga}$ generator based on nano-SnO${ }_{2}$ for PET imaging. Sci. Rep. 2020, 10, 12756. [CrossRef]

17. Dash, A.; Chakravarty, R. Radionuclide generators: The prospect of availing PET radiotracers to meet current clinical needs and future research demands. Am. J. Nucl. Med. Mol. Imaging 2019, 9, 30-66.

18. Boschi, A.; Uccelli, L.; Martini, P. A Picture of Modern Tc-99m Radiopharmaceuticals: Production, Chemistry, and Applications in Molecular Imaging. Appl. Sci. 2019, 9, 2526. [CrossRef]

19. Wang, C.; Wang, X.; Chan, H.; Chan, H.-N.; Liu, G.; Wang, Z.; Li, H.; Li, H.-W.; Wong, M.S. Amyloid- $\beta$ Oligomer-Targeted Gadolinium-Based NIR/MR Dual-Modal Theranostic Nanoprobe for Alzheimer's Disease. Adv. Funct. Mater. 2020, 30, 1909529. [CrossRef]

20. Abbott, N.J.; Patabendige, A.A.K.; Dolman, D.E.M.; Yusof, S.R.; Begley, D.J. Structure and function of the blood-brain barrier. Neurobiol. Dis. 2010, 37, 13-25. [CrossRef]

21. Daneman, R.; Prat, A. The Blood-Brain Barrier. Cold Spring Harb. Perspect. Biol. 2015, 7, a020412. [CrossRef]

22. He, Q.; Liu, J.; Liang, J.; Liu, X.; Li, W.; Liu, Z.; Ding, Z.; Tuo, D. Towards improvements for penetrating the blood-brain barrier-Recent progress from a material and pharmaceutical perspective. Cells 2018, 7, 24. [CrossRef] 
23. Rautio, J.; Laine, K.; Gynther, M.; Savolainen, J. Prodrug approaches for CNS delivery. AAPS J. 2008, 10, 92-102. [CrossRef]

24. Aryal, M.; Arvanitis, C.D.; Alexander, P.M.; McDannold, N. Ultrasound-mediated blood-brain barrier disruption for targeted drug delivery in the central nervous system. Adv. Drug Deliv. Rev. 2014, 72, 94-109. [CrossRef]

25. Polat, B.E.; Blankschtein, D.; Langer, R. Low-frequency sonophoresis: Application to the transdermal delivery of macromolecules and hydrophilic drugs. Expert Opin. Drug Deliv. 2010, 7, 1415-1432. [CrossRef]

26. Wood, I.S.; Trayhurn, P. Glucose transporters (GLUT and SGLT): Expanded families of sugar transport proteins. Br. J. Nutr. 2007, 89, 3-9. [CrossRef] [PubMed]

27. Oddo, A.; Peng, B.; Tong, Z.; Wei, Y.; Tong, W.Y.; Thissen, H.; Voelcker, N.H. Advances in Microfluidic Blood-Brain Barrier (BBB) Models. Trends Biotechnol. 2019, 12, 1295-1314. [CrossRef]

28. Di Lullo, E.; Kriegstein, A.R. The use of brain organoids to investigate neural development and disease. Nat. Rev. Neurosci. 2017, 18, 573-584. [CrossRef]

29. Salman, M.M.; Marsh, G.; Kusters, I.; Delincé, M.; Di Caprio, G.; Upadhyayula, S.; de Nola, G.; Hunt, R.; Ohashi, K.G.; Gray, T.; et al. Design and Validation of a Human Brain Endothelial Microvessel-on-a-Chip Open Microfluidic Model Enabling Advanced Optical Imaging. Front. Bioeng. Biotechnol. 2020, 8, 1077. [CrossRef]

30. Mensch, J.; Oyarzabal, J.; Mackie, C.; Augustijns, P. In vivo, in vitro and in silico methods for small molecule transfer across the BBB. J. Pharm. Sci. 2009, 98, 4429-4468. [CrossRef]

31. Van de Waterbeemd, H.; Camenisch, G.; Folkers, G.; Chretien, J.R.; Raevsky, O.A. Estimation of blood-brain barrier crossing of drugs using molecular size and shape, and H-bonding descriptors. J.Drug Target 1998, 6, 151-165. [CrossRef]

32. Sedgwick, A.C.; Brewster II, J.T.; Harvey, P.; Iovan, D.A.; Smith, G.; He, X.-P.; Tian, H.; Sessler, J.L.; James, T.D. Metal-based imaging agents: Progress towards interrogating neurodegenerative disease. Chem. Soc. Rev. 2020, 49, 2886-2915. [CrossRef]

33. Gomes, L.M.F.; Bataglioli, J.C.; Storr, T. Metal complexes that bind to the amyloid- $\beta$ peptide of relevance to Alzheimer's disease. Coord. Chem. Rev. 2020, 412, 213255. [CrossRef]

34. Liu, H.; Qu, Y.; Wang, X. Amyloid $\beta$-targeted metal complexes for potential applications in Alzheimer's disease. Future Med. Chem. 2018, 10, 679-701. [CrossRef]

35. Daghighian, F.; Sumida, R.; Phelps, M.E. PET Imaging: An Overview and Instrumentation. J. Nucl. Med. Technol. 1990, 18, 5-15.

36. Sin, I.; Kang, C.S.; Bandara, N.; Sun, X.; Zhong, Y.L.; Rogers, B.E.; Chong, H.S. Novel hexadentate and pentadentate chelators for 64Cu-based targeted PET imaging. Bioorg. Med. Chem. 2014, 22, 2553-2562. [CrossRef]

37. Kim, D.-K.; Song, J.-W.; Park, J.-D.; Choi, B.-S. Copper induces the accumulation of amyloid-beta in the brain. Mol. Cell. Toxicol. 2013, 9, 57-66. [CrossRef]

38. Liu, T.; Karlsen, M.; Karlberg, A.M.; Redalen, K.R. Hypoxia imaging and theranostic potential of $\left[{ }^{64} \mathrm{Cu}\right][\mathrm{Cu}(\mathrm{ATSM})]$ and ionic $\mathrm{Cu}(\mathrm{II})$ salts: A review of current evidence and discussion of the retention mechanisms. Eur. J. Nucl. Med. Mol. Imaging 2020, 10, 33. [CrossRef]

39. Sharma, A.K.; Schultz, J.W.; Prior, J.T.; Rath, N.P.; Mirica, L.M. Coordination Chemistry of Bifunctional Chemical Agents Designed for Applications in 64Cu PET Imaging for Alzheimer's Disease. Inorg. Chem. 2017, 56, 13801-13814. [CrossRef]

40. Lim, S.; Paterson, B.M.; Fodero-Tavoletti, M.T.; O’Keefe, G.J.; Cappai, R.; Barmham, K.J.; Villemagne, V.L.; Donnelly, P.S. A copper radiopharmaceutical for diagnostic imaging of Alzheimer's disease: A bis (thiosemicarbazonato)copper(II) complex that binds to amyloid- $\beta$ plaques. Chem. Commun. 2010, 46, 5437-5439. [CrossRef]

41. Hickey, J.L.; Lim, S.; Hayne, D.J.; Paterson, B.M.; White, J.M.; Villemagne, V.L.; Roselt, P.; Binns, D.; Cullinane, C.; Jeffery, C.M.; et al. Diagnostic Imaging Agents for Alzheimer's Disease: Copper Radiopharmaceuticals that Target A $\beta$ Plaques. J. Am. Chem. Soc. 2013, 135, 16120-16132. [CrossRef] [PubMed]

42. McInnes, L.E.; Noor, A.; Kysenius, K.; Cullinane, C.; Roselt, P.; McLean, C.A.; Chiu, F.C.K.; Powell, A.K.; Crouch, P.J.; White, J.M.; et al. Potential Diagnostic Imaging of Alzheimer's Disease with Copper-64 Complexes That Bind to Amyloid- $\beta$ Plaques. Inorg. Chem. 2019, 58, 3382-3395. [CrossRef] [PubMed] 
43. McInnes, L.E.; Noor, A.; Roselt, P.D.; McLean, C.A.; White, J.M.; Donnelly, P.S. A Copper Complex of a Thiosemicarbazone-Pyridylhydrazone Ligand Containing a Vinylpyridine Functional Group as a Potential Imaging Agent for Amyloid- $\beta$ Plaques. Aust. J. Chem. 2019, 72, 827. [CrossRef]

44. Noor, A.; Hayne, D.J.; Lim, S.; Van Zuylekom, J.K.; Cullinane, C.; Roselt, P.D.; McLean, C.A.; White, J.M.; Donnelly, P.S. Copper Bis(thiosemicarbazonato)-stilbenyl Complexes That Bind to Amyloid- $\beta$ Plaques. Inorg. Chem. 2020, 59, 11658-11669. [CrossRef] [PubMed]

45. Paterson, B.M.; Cullinane, C.; Crouch, P.J.; White, A.R.; Barnham, K.J.; Roselt, P.D.; Noonan, W.; Binns, D.; Hicks, R.J.; Donnelly, P.S. Modification of Biodistribution and Brain Uptake of Copper Bis(thiosemicarbazonato) Complexes by the Incorporation of Amine and Polyamine Functional Groups. Inorg. Chem. 2019, 58, 4540-4552. [CrossRef]

46. Watanabe, H.; Kawasaki, A.; Sano, K.; Ono, M.; Saji, H. Synthesis and evaluation of copper-64 labeled benzofuran derivatives targeting $\beta$-amyloid aggregates. Bioorg. Med. Chem. 2016, 24, 3618-3623. [CrossRef]

47. Bandara, N.; Sharma, A.K.; Krieger, S.; Schultz, J.W.; Han, B.H.; Rogers, B.E.; Mirica, L.M. Evaluation of 64Cu-Based Radiopharmaceuticals that Target A $\beta$ Peptide Aggregates as Diagnostic Tools for Alzheimer's Disease. J. Am. Chem. Soc. 2017, 139, 12550-12558. [CrossRef]

48. Huang, Y.; Cho, H.-J.; Bandara, N.; Sun, L.; Tran, D.; Rogers, B.E.; Mirica, L.M. Metal-chelating benzothiazole multifunctional compounds for the modulation and ${ }^{64} \mathrm{Cu}$ PET imaging of $\mathrm{A} \beta$ aggregation. Chem. Sci. 2020, 11, 7789-7799. [CrossRef]

49. Sharma, A.K.; Pavlova, S.T.; Kim, J.; Finkelstein, D.; Hawco, N.J.; Rath, N.P.; Kim, J.; Mirica, L.M. Bifunctional Compounds for Controlling Metal-Mediated Aggregation of the $\mathrm{A} \beta_{42}$ Peptide. J. Am. Chem. Soc. 2012, 134, 6625-6636. [CrossRef]

50. Sharma, A.K.; Kim, J.; Prior, J.T.; Hawco, N.J.; Rath, N.P.; Kim, J.; Mirica, L.M. Small Bifunctional Chelators That Do Not Disaggregate Amyloid $\beta$ Fibrils Exhibit Reduced Cellular Toxicity. Inorg. Chem. 2014, 53, 11367-11376. [CrossRef]

51. Banerjee, S.R.; Pomper, M.G. Clinical applications of Gallium-68. Appl. Radiat. Isot. 2013, 76, 2-13. [CrossRef] [PubMed]

52. Moerlein, S.M.; Welch, M.J. The chemistry of gallium and indium as related to radiopharmaceutical production. Int. J. Nucl. Med. Biol. 1981, 8, 277-287. [CrossRef]

53. Zhou, Z.; Lu, Z.-R. Gadolinium-based contrast agents for magnetic resonance cancer imaging. Wiley Interdiscip. Rev. Nanomed. Nanobiotechnol. 2013, 5, 1-18. [CrossRef] [PubMed]

54. Caravan, P.; Ellison, J.J.; McMurry, T.J.; Lauffer, R.B. Gadolinium(III) Chelates as MRI Contrast Agents: Structure, Dynamics, and Applications. Chem. Rev. 1999, 99, 2293-2352. [CrossRef]

55. Martins, A.F.; Morfin, J.-F.; Kubíčková, A.; Kubíček, V.; Buron, F.; Suzenet, F.; Salerno, M.; Lazar, A.N.; Duyckaerts, C.; Arlicot, N.; et al. PiB-Conjugated, Metal-Based Imaging Probes: Multimodal Approaches for the Visualization of $\beta$-Amyloid Plaques. ACS Med. Chem. Lett. 2013, 4, 436-440. [CrossRef]

56. Martins, A.F.; Morfin, J.-F.; Geraldes, C.F.G.C.; Tóth, É. Gd ${ }^{3+}$ complexes conjugated to Pittsburgh compound B: Potential MRI markers of $\beta$-amyloid plaques. J. Biol. Inorg. Chem. 2014, 19, 281-295. [CrossRef]

57. Bort, G.; Catoen, S.; Borderies, H.; Kebsi, A.; Ballet, S.; Louin, G.; Port, M.; Ferroud, C. Gadolinium-based contrast agents targeted to amyloid aggregates for the early diagnosis of Alzheimer's disease by MRI. Eur. J. Med. Chem. 2014, 87, 843-861. [CrossRef]

58. Watanabe, H.; Ono, M.; Iikuni, S.; Yoshimura, M.; Matsumura, K.; Kimura, H.; Saji, H. A ${ }^{68}$ Ga complex based on benzofuran scaffold for the detection of $\beta$-amyloid plaques. Bioorg. Med. Chem. Lett. 2014, 24, 4834-4837. [CrossRef]

59. Cressier, D.; Dhilly, M.; Cao Pham, T.T.; Fillesoye, F.; Gourand, F.; Maïza, A.; Martins, A.F.; Morfin, J.-F.; Geraldes, C.F.G.C.; Tóth, É.; et al. Gallium-68 Complexes Conjugated to Pittsburgh Compound B: Radiolabeling and Biological Evaluation. Mol. Imaging Biol. 2016, 18, 334-343. [CrossRef]

60. Zha, Z.; Song, J.; Choi, S.R.; Wu, Z.; Ploessl, K.; Smith, M.; Kung, H. ${ }^{68}$ Ga-Bivalent Polypegylated Styrylpyridine Conjugates for Imaging A $\beta$ Plaques in Cerebral Amyloid Angiopathy. Bioconjug. Chem. 2016, 27, 1314-1323. [CrossRef]

61. Chauhan, K.; Datta, A.; Adhikari, A.; Chuttani, K.; Singh, A.K.; Mishra, A.K. ${ }^{68}$ Ga based probe for Alzheimer's disease: Synthesis and preclinical evaluation of homodimeric chalcone in $\beta$-amyloid imaging. Org. Biomol. Chem. 2014, 12, 7328. [CrossRef] [PubMed] 
62. Asti, M.; Ferrar, E.; Croci, S.; Atti, G.; Rubagotti, S.; Iori, M.; Capponi, P.C.; Zerbini, A.; Saladini, M.; Versari, A. Synthesis and Characterization of ${ }^{68} \mathrm{Ga}$-Labeled Curcumin and Curcuminoid Complexes as Potential Radiotracers for Imaging of Cancer and Alzheimer's Disease. Inorg. Chem. 2014, 53, 4922-4933. [CrossRef] [PubMed]

63. Rubagotti, S.; Croci, S.; Ferrari, E.; Iori, M.; Capponi, P.C.; Lorenzini, L.; Calzà, L.; Versari, A.; Asti, M. Affinity of (nat/68)Ga-Labelled Curcumin and Curcuminoid Complexes for $\beta$-Amyloid Plaques: Towards the Development of New Metal-Curcumin Based Radiotracers. Int. J. Mol. Sci. 2016, 17, 1480. [CrossRef] [PubMed]

64. Lange, J.L.; Hayne, D.J.; Roselt, P.; McLean, C.A.; White, J.M.; Donnelly, P.S. A gallium(III) Schiff base-curcumin complex that binds to amyloid- $\beta$ plaques. J. Inorg. Biochem. 2016, 162, 274-279. [CrossRef]

65. Orteca, G.; Sinnes, J.-P.; Rubagotti, S.; Iori, M.; Capponi, P.C.; Piel, M.; Rösch, F.; Ferrari, E.; Asti, M. Gallium-68 and scandium-44 labelled radiotracers based on curcumin structure linked to bifunctional chelators: Synthesis and characterization of potential PET radiotracers. J. Inorg. Biochem. 2020, 204, 110954.

66. Gniazdowska, E.; Koźmiński, P.; Halik, P.; Bajda, M.; Czarnecka, K.; Mikiciuk-Olasik, E.; Masłowska, K.; Rogulski, Z.; Cheda, Ł.; Kilian, K.; et al. Synthesis, physicochemical and biological evaluation of tacrine derivative labeled with technetium-99m and gallium-68 as a prospective diagnostic tool for early diagnosis of Alzheimer's disease. Bioorg. Chem. 2019, 91, 103136. [CrossRef]

67. Singh, S.; Khar, A. Biological Effects of Curcumin and Its Role in Cancer Chemoprevention and Therapy. AntiCancer Agents Med. Chem. 2006, 6, 933-946. [CrossRef]

68. Bartik, L.; Whitfield, G.K.; Kaczmarska, M.; Lowmiller, C.L.; Moffet, E.W.; Furmick, J.K.; Hernandez, Z.; Haussler, C.A.; Haussler, M.R.; Jurutka, P.W. Curcumin: A novel nutritionally derived ligand of the vitamin D receptor with implications for colon cancer chemoprevention. J. Nutr. Biochem. 2010, 21, 1153-1161. [CrossRef]

69. Chen, M.; Du, Z.Y.; Zheng, X.; Li, D.L.; Zhou, R.P.; Zhang, K. Use of curcumin in diagnosis, prevention, and treatment of Alzheimer's disease. Neural Regen. Res. 2018, 13, 742-752.

70. Sidiqi, A.; Wahl, D.; Lee, S.; Ma, D.; To, E.; Cui, J.; To, E.; Beg, M.F.; Sarunic, M.; Matsubara, J.A. In vivo Retinal Fluorescence Imaging with Curcumin in an Alzheimer Mice Model. Front. Neurosci. 2020, 14, 713. [CrossRef]

71. McCrate, O.A.; Zhou, X.; Cegelski, L. Curcumin as an amyloid-indicatordye in E. coli. Chem. Commun. 2013, 49, 4193-4195. [CrossRef] [PubMed]

72. Thapa, A.; Jett, S.D.; Chi, E.Y. Curcumin Attenuates Amyloid- $\beta$ Aggregate Toxicity and Modulates Amyloid- $\beta$ Aggregation Pathway. ACS Chem. Neurosci. 2016, 7, 56-68. [CrossRef] [PubMed]

73. Teoh, C.L.; Su, D.; Sahu, S.; Yun, S.-W.; Drummond, E.; Prelli, F.; Lim, S.; Cho, S.; Ham, S.; Wisniewski, T.; et al. Chemical Fluorescent Probe for Detection of A $\beta$ Oligomers. J. Am. Chem. Soc. 2015, 137, 13503-13509. [CrossRef] [PubMed]

74. Ono, K.; Hasegawa, K.; Naiki, H.; Yamada, M.J. Curcumin has potent anti-amyloidogenic effects for Alzheimer's $\beta$-amyloid fibrils in vitro. Neurosci. Res. 2004, 75, 742-750. [CrossRef] [PubMed]

75. Yang, J.; Cheng, R.; Fu, H.; Yang, J.; Kumar, M.; Lu, J.; Xu, Y.; Liang, S.H.; Cui, M.; Ran, C. Half-curcumin analogues as PET imaging probes for amyloid beta species. Chem. Comm. 2019, 55, 3630-3633. [CrossRef] [PubMed]

76. Sherin, S.; Balachandran, S.; Abraham, A. Curcumin incorporated titanium dioxide nanoparticles as MRI contrasting agent for early diagnosis of atherosclerosis- rat model. Vet. Anim. Sci. 2020, 10, 100090. [CrossRef] [PubMed]

77. Ono, M.; Haratake, M.; Mori, H.; Nakayama, M. Novel chalcones as probes for in vivo imaging of beta-amyloid plaques in Alzheimer's brains. Bioorg. Med. Chem. 2007, 15, 6802-6809. [CrossRef]

78. Yang, F.; Lim, G.P.; Begum, A.N.; Ubeda, O.J.; Simmons, M.R.; Ambegaokar, S.S.; Chen, P.P.; Kayed, R.; Glabe, C.G.; Frautschy, S.A.; et al. Curcumin Inhibits Formation of Amyloid $\beta$ Oligomers and Fibrils, Binds Plaques, and Reduces Amyloid in Vivo. J. Biol. Chem. 2005, 280, 5892-5901. [CrossRef]

79. Jeyarasasingam, G.; Yeluashvili, M.; Quik, M. Tacrine, a reversible acetylcholinesterase inhibitor, induces myopathy. NeuroReport 2000, 11, 1173-1176. [CrossRef]

80. Meszaros, L.K.; Dose, A.; Biagini, S.C.G.; Blower, P.J. Synthesis and evaluation of analogues of HYNIC as bifunctional chelators for technetium. Dalton Trans. 2011, 40, 6260-6267. [CrossRef] 
81. Fissers, J.; Waldron, A.-M.; De Vijlder, T.; Van Broeck, B.; Pemberton, D.J.; Mercken, M.; Van Der Veken, P.; Joossens, J.; Augustyns, K.; Dedeurwaerdere, S.; et al. Synthesis and Evaluation of a Zr-89-Labeled Monoclonal Antibody for Immuno-PET Imaging of Amyloid- $\beta$ Deposition in the Brain. Mol. Imaging Biol. 2016, 18, 598-605. [PubMed]

82. Jia, J.; Cui, M.; Dai, J.; Wang, X.; Ding, Y.-S.; Jia, H.; Liu, B. ${ }^{99 \mathrm{~m}}$ Tc-labeled benzothiazole and stilbene derivatives as imaging agents for $\mathrm{A} \beta$ plaques in cerebral amyloid angiopathy. Med. Chem. Comm. 2014, 5, $153-158$. [CrossRef]

83. Li, Z.; Cui, M.; Dai, J.; Wang, X.; Yu, P.; Yang, Y.; Jia, J.; Fu, H.; Ono, M.; Jia, H.; et al. Novel Cyclopentadienyl Tricarbonyl Complexes of ${ }^{99 \mathrm{~m}}$ Tc Mimicking Chalcone as Potential Single-Photon Emission Computed Tomography Imaging Probes for $\beta$-Amyloid Plaques in Brain. J. Med. Chem. 2013, 56, 471-482. [CrossRef] [PubMed]

84. Yang, Y.; Cui, M.; Jin, B.; Wang, X.; Li, Z.; Yu, P.; Jia, J.; Fu, H.; Jia, H.; Liu, B. ${ }^{99 m}$ Tc-labeled dibenzylideneacetone derivatives as potential SPECT probes for in vivo imaging of $\beta$-amyloid plaque. Eur. J. Med. Chem. 2013, 64, 90-98. [CrossRef] [PubMed]

85. Iikuni, S.; Ono, M.; Watanabe, H.; Matsumura, K.; Yoshimura, M.; Harada, N.; Kimura, H.; Nakayama, M.; Saji, H. Enhancement of Binding Affinity for Amyloid Aggregates by Multivalent Interactions of ${ }^{99 \mathrm{~m}}$ Tc-Hydroxamamide Complexes. Mol. Pharm. 2014, 11, 1132-1139. [CrossRef]

86. Iikuni, S.; Ono, M.; Watanabe, H.; Matsumura, K.; Yoshimura, M.; Kimura, H.; Ishibashi-Ueda, H.; Okamoto, Y.; Ihara, M.; Saji, H. Imaging of Cerebral Amyloid Angiopathy with Bivalent ${ }^{99} \mathrm{~m}$ Tc-Hydroxamamide Complexes. Sci. Rep. 2016, 6, 25990. [CrossRef]

87. Hayne, D.J.; North, A.J.; Fodero-Tavoletti, M.; White, J.M.; Hung, L.W.; Rigopoulos, A.; McLean, C.A.; Adlard, P.A.; Ackermann, U.; Tochon-Danguy, H.; et al. Rhenium and technetium complexes that bind to amyloid- $\beta$ plaques. Dalton Trans. 2015, 44, 4933-4944. [CrossRef]

88. Wang, X.; Cui, M.; Jia, J.; Liu, B. ${ }^{99 \mathrm{~m}}$ Tc-labeled-2-arylbenzoxazole derivatives as potential A $\beta$ imaging probes for single-photon emission computed tomography. Eur. J. Med. Chem. 2015, 89, 331-339. [CrossRef]

89. Jia, J.; Cui, M.; Dai, J.; Liu, B. ${ }^{99} \mathrm{~m} \mathrm{Tc}(\mathrm{CO})_{3}$-Labeled Benzothiazole Derivatives Preferentially Bind Cerebrovascular Amyloid: Potential Use as Imaging Agents for Cerebral Amyloid Angiopathy. Mol. Pharm. 2015, 12, 2937-2946. [CrossRef]

90. Zhang, X.; Yu, P.; Yang, Y.; Hou, Y.; Peng, C.; Liang, Z.; Lu, J.; Chen, B.; Dai, J.; Liu, B.; et al. 99m Tc-Labeled 2-Arylbenzothiazoles: A $\beta$ Imaging Probes with Favorable Brain Pharmacokinetics for Single-Photon Emission Computed Tomography. Bioconj. Chem. 2016, 27, 2493-2504. [CrossRef]

91. Hayne, D.J.; White, J.M.; McLean, C.A.; Villemagne, V.L.; Barnham, K.J.; Donnelly, P.S. Synthesis of Oxorhenium(V) and Oxotechnetium(V) Complexes That Bind to Amyloid- $\beta$ Plaques. Inorg. Chem. 2016, 55, 7944-7953. [CrossRef] [PubMed]

92. Kiritsis, C.; Mavroidi, B.; Shegani, A.; Palamaris, L.; Loudos, G.; Sagnou, M.; Pirmettis, I.; Papadopoulos, M.; Pelecanou, M. 2-(4'-Aminophenyl)benzothiazole Labeled with ${ }^{99} \mathrm{~m}$ Tc-Cyclopentadienyl for Imaging $\beta$-Amyloid Plaques. ACS Med. Chem. Lett. 2017, 8, 1089-1092. [CrossRef] [PubMed]

93. Iikuni, S.; Ono, M.; Tanimura, K.; Watanabe, H.; Yoshimuraa, M.; Sajia, H. Synthesis and biological evaluation of novel technetium-99m-labeled phenylquinoxaline derivatives as single photon emission computed tomography imaging probes targeting $\beta$-amyloid plaques in Alzheimer's disease. RSC Adv. 2017, 7, 20582-20590. [CrossRef]

94. Fletcher, S.P.; Noor, A.; Hickey, J.L.; McLean, C.A.; White, J.M.; Donnelly, P.S. Rhenium and technetium complexes of thioamide derivatives of pyridylhydrazine that bind to amyloid- $\beta$ plaques. J. Biol. Inorg. Chem. 2018, 23, 1139-1151. [CrossRef] [PubMed]

95. Molavipordanjani, S.; Emami, S.; Mardanshahi, A.; Amiri, F.T.; Noaparast, Z.; Hosseinimehr, S.J. Novel ${ }^{99 m}$ Tc-2-arylimidazo[2,1-b]benzothiazole derivatives as SPECT imaging agents for amyloid- $\beta$ plaques. Eur. J. Med. Chem. 2019, 175, 149-161. [CrossRef] [PubMed]

96. Sagnou, M.; Mavroidi, B.; Shegani, A.; Paravatou-Petsotas, M.; Raptopoulou, C.; Psycharis, V.; Pirmettis, I.; Papadopoulos, M.S.; Pelecanou, M. Remarkable Brain Penetration of Cyclopentadienyl $\mathrm{M}(\mathrm{CO})_{3}{ }^{+}\left(\mathrm{M}={ }^{99} \mathrm{~m} \mathrm{Tc}\right.$, $\mathrm{Re})$ Derivatives of Benzothiazole and Benzimidazole Paves the Way for Their Application as Diagnostic, with Single-Photon-Emission Computed Tomography (SPECT), and Therapeutic Agents for Alzheimer's Disease. J. Med. Chem. 2019, 62, 2638-2650. [PubMed] 
97. Jokar, S.; Behnammanesh, H.; Erfani, M.; Sharifzadeh, M.; Gholami, M.; Sabzevari, O.; Amini, M.; Geramifae, P.; Hajiramezanali, M.; Beiki, D. Synthesis, biological evaluation and preclinical study of a novel ${ }^{99 \mathrm{~m}}$ Tc-peptide: A targeting probe of amyloid- $\beta$ plaques as a possible diagnostic agent for Alzheimer's disease. Bioorg. Chem. 2020, 99, 103857. [CrossRef]

Publisher's Note: MDPI stays neutral with regard to jurisdictional claims in published maps and institutional affiliations.

(C) 2020 by the authors. Licensee MDPI, Basel, Switzerland. This article is an open access article distributed under the terms and conditions of the Creative Commons Attribution (CC BY) license (http://creativecommons.org/licenses/by/4.0/). 